\title{
New Insights into Broad Spectrum Communities of the Early Holocene Near East: The Birds of Hallan Çemi
}

Melinda A. Zeder ${ }^{1 *}$ and Megan Spitzer ${ }^{2}$

1 - Program in Human Ecology and Archaeobiology, Department of Anthropology, National Museum of Natural History, Smithsonian Institution, Santa Fe Institute, 1399 Hyde Park Road, Santa Fe, NM 87501, USA; ; 2- Division of Birds, Department of Vertebrate Zoology, National Museum of Natural History Smithsonian Institution; * Corresponding Author, zederm@si.edu

Key Words: Broad Spectrum Revolution, Early Holocene, Avifauna, eastern Fertile Crescent

\begin{abstract}
The Early Holocene in Near East was a pivotal transitional period that witnessed dramatic changes in climate and environment, human settlement, major changes in subsistence strategies focusing on a broad range of different plant and animal resources, and a radical restructuring of social relations. The remarkable corpus of avifauna from the Early Holocene site of Hallan Çemi in southeastern Turkey sheds new light on key issues about this dynamic period that has been termed the "Broad Spectrum Revolution". The avifauna from this important site demonstrate how Hallan Çemi occupants took advantage of the site's strategic location at the junction of multiple environmental zones by extracting a diverse range of seasonally available resources from both near-by and more distant eco-zones to cobble together a stable subsistence economy capable of supporting this small community throughout the year. They give testimony to the impacts of resource utilization over time, especially on species unable to rebound from sustained human hunting. At the same time, they show how Hallan Çemi residents mitigated these impacts by replacing depleted resources with alternative, more resilient ones that could be more sustainably harvested. They open a window onto the growing investment in feasting and ritual activity that helped bind this community together. In so doing they provide a means of empirically evaluating the efficacy of contrasting explanatory frameworks for the Broad Spectrum Revolution that gave rise to the subsequent domestication of plant and animals in the Near East. Contrary to frameworks that cast these developments as responses to resource depression, lessons learned from the Hallan Çemi avifauna lend support to frameworks that emphasize the human capacity to strategically target, capitalize, and improve upon circumscribed resource rich environments in a way that permits more permanent occupation of these niches. And they underscore the degree to which social and ritual activities work together with ecological and economic facets of the lives of
\end{abstract}


these people to both perpetuate and reshape these communities on the threshold of domestication and the emergence of agriculture.

\section{Introduction}

The Early Holocene was a time of revolutionary change in the Near East. Across the entire arc of the Fertile Crescent the period following the end of the Younger Dryas climatic downturn (c. 11,700-10,500 BP, all dates are in calibrated years before present) saw the proliferation of small semi- to fully sedentary communities strategically situated at the junction of multiple eco-zones and supported by a broad spectrum subsistence base consisting of a diverse array of species, including many previously ignored plant and smaller game species. Increasing investment in economically important species within these environments resulted in deepening co-evolutionary relationships that, with certain particularly receptive species, led to their domestication (Zeder 2011, 2012a). In these Late Epipaleolithic/Early Neolithic communities the Broad Spectrum Revolution was accompanied by radical restructuring of social networks facilitated by the emergence of a new symbolic repertoire and range of ritual activities that seem to have been equally important as the restructuring of subsistence activities in ushering in this dramatic new way of life (Cauvin 2000; Watkins 2010). This transformational period, termed the Broad Spectrum Revolution (BSR) in an early influential article by Kent Flannery (Flannery 1969), set the stage for the initial domestication in the Near East which had clearly been accomplished for both plants and animals by 10,500 BP (Zeder 2011). As a result, the BSR has been the focus of researchers proposing various different explanatory frameworks for this major transition in human history. Some of these frameworks cast these developments in the context of resource depression caused by an explosive demographic growth and subsequent population packing at the beginning of the Holocene (e.g., Stiner 2001; Stutz et al. 2009). Others, in contrast, see these developments as a response to new opportunities arising from climate amelioration (Zeder 2012a). 
Recent research is providing important new detail on the nature of subsistence economy in these communities and the interplay between economy, social organization, and ritual activity that sustained them - empirical evidence that is vital in sorting between various conflicting explanatory frameworks for these developments. One component of the faunal assemblages from these sites has proven particularly useful in this regard. Studies of the rich and diverse avifauna from these sites are providing new insights into the evolution of subsistence strategies during this period, the ways in which inhabitants exploited the resource rich eco-zones surrounding these communities, the seasonal nature of occupation and resource exploitation, and, importantly, the role of animals (as food and as components of an evolving symbolic system) in facilitating the ritual activities that provided the glue that kept these communities together (Dobney et al. 1999; Gourichon 2002; Gourichon and Helmer 2004; Martin et al. 2013; Reicchi and Gopher 2002; Russell and McGowan 2003; Simmons and Nadel 1998; Solecki and McGovern 1980; Tchernov 1993). The large corpus of avifauna from the Epipaleolithic site of Hallan Çemi adds to this increasingly well-resolved picture.

\section{Hallan Çemi}

Hallan Çemi is one of the earliest of a number of small communities that sprang up across the eastern Taurus/Zagros arc at the beginning of the Early Holocene (Peasnall 2000, Figure 1). Like other sites of the Taurus/Zagros "Round House" tradition, Hallan Çemi was situated on a small watercourse at the junction of multiple environmental zones and consisted of a few small round houses located around a central activity area (Figure 2). Salvage excavations conducted at the site by Michael Rosenberg in the 1990s encountered three building levels, and traces of a fourth level (Peasnall 2000; Rosenberg and Davis 1992; Rosenberg and Redding 2000; Rosenberg et al. 1998). Over time there is evidence of an increase in both the number and size of houses. Two especially large houses ( $A$ and $B$ ) appear in the latest building level (BL 1) that contained a concentration of obsidian and copper ore and, in House A, an aurochs bucranium. 
These larger houses are proposed to have served some kind of community-wide function. The houses are organized in a semi-circle around a $15 \mathrm{~m}$ in diameter area enclosing the central activity area (CAA). The CAA is comprised of deposits containing a dense concentration of fire-cracked rock and animal bones, with a number of articulated limb elements of large game animals and whole skulls of sheep and goats. The area is thought to have been the focus of community feasts (Rosenberg et al. 1998; Rosenberg and Redding 2000). An exploratory sounding through the CAA (Figure 2a and 2b) found large quantities of fire-cracked rocks and large animal bones continuing down to virgin soil at about $4.3 \mathrm{~m}$ - more than $2 \mathrm{~m}$ below the depth of the third building level. AMS dates taken from this sounding are all very similar suggesting a remarkably short occupation at the site of about 300 years from about 11,700-11,400 BP (Starkovich and Stiner 2009). Reasons for the abandonment of Hallan Çemi are unclear, but there is some evidence that its inhabitants relocated to the site of Demirkoy some $40 \mathrm{~km}$ downstream of Hallan Çemi (Peasnall 2000). This kind of short-term occupation and relocation is common during the early phase of this Round House tradition in the eastern Fertile Crescent (c. 11,700-11,400 BP). Late Round House communities (c. $11,400-10,500$ BP) are also strategically located with access to multiple environmental zones (though many are located in more steppic areas farther from the mountains) and have the same general site plan. These communities tend to be occupied for longer periods of time, with evidence of an elaboration of ritual activities that may have been directed toward promoting community cohesion to combat an evident shift away from communal to more individualized, household level control over access to resources (Peasnall 2000).

Over the course of four short excavation seasons conducted in advance of the completion of a dam on the Batman river that has subsequently flooded the area, a huge quantity of well-preserved faunal remains (estimated at nearly two metric tons in weight) was recovered. Studies of portions of this huge assemblage have been conducted by Richard Redding of the University of Michigan (Redding 2005; Rosenberg and Redding 2000; Rosenberg et al. 1998) and Britt Starkovich and Mary Stiner at the 
University of Arizona (Starkovich and Stiner 2009). From 2010 to 2014, Melinda Zeder led a team at the Smithsonian Institution (the repository for the assemblage) that analyzed over 200,000 bones from all areas of the site, with 53,341 of these identifiable to some level of taxonomic specificity (Table 1, Table S1). This sample represents all but a subset of the assemblage from the deep sounding in the CAA, which Redding retains for study. Megan Spitzer was responsible for the analysis of the 2388 avian bones in the Smithsonian collection, 1154 of which (48\%) she was able to identify to at least the level of family using the skeletal collections of the Bird Division of the NMNH Department of Vertebrate Zoology and referring to photographs of skeleton specimens (Aquila heliaca, A. clanga, A. nipalensis, A. pennata) at the Senckenberg Natural History Museum (Table 2 , Tables S2-4). At only $5 \%$ of the huge assemblage of identifiable bones from the site, birds were a relatively minor component in the diet of Hallan Çemi residents. The information they provide about the lives of these people, and about the Early Holocene communities in the Fertile Crescent more generally, however, far outweighs their numbers.

\section{Hallan Çemi avifauna}

Identifiable bird bones from Hallan Çemi represent at least 51 different taxa from 20 different families and 13 orders of birds (Table S2-S4). These taxa can be grouped into seven different general types or classes (Table 2, Figure 3). Gamebirds, comprised of a number of land-based, ground-feeding birds are the best represented in both number of bones (Table 2a) and in weight (Table 2 b), a rough proxy for meat contribution. This class of birds is dominated by the Grey Partridge (Perdix perdix) and the Great Bustard (Otis tarda), with Chukar (Alectoris cf. chukar) a distant third. Other gamebirds represented in small numbers include a species of quail (Coturnix coturnix), a pigeon (Columba cf. palumbus), a sandgrouse (Pterocles cf. orientalis), and a smaller bustard species (Tetrax tetrax).

Waterfowl are the second most important class of birds. This class is dominated by a large species of goose (most likely either the Greylag Goose, Anser anser, or the 
Bean Goose, A. fabalis), with one specimen identified as the smaller Greater Whitefronted Goose ( $A$. albifrons). It also includes smaller numbers of nine different varieties of diving and dabbling ducks - including five species belonging to the genus Anas ( $A$. acuta, A. crecca, A. platyrhynchos, and A. querquedula), a pochard (Aythya cf. ferina), a merganser (Mergus merganser), a smew (Mergellus albellus), and a shelduck (Tardona cf. ferruginea). Also included in this class of birds is a single bone tentatively identified as swan (Cygnus sp.), the only other large waterfowl represented at the site.

Raptors are the third most common group at Hallan Çemi and can be divided into large and small raptors. Large raptors include an as yet unidentified eagle species (Aquila sp.). Based on size, the majority of these specimens are most likely Imperial Eagle ( $A$. heliaca), rather than the larger, more robust Golden Eagle ( $A$. chrysaetos). One specimen, however, is the size of the smaller spotted eagles ( $A$. clanga and $A$. pomarina). Other large raptors include, Eurasian Eagle-Owl (Bubo bubo), and two varieties of vulture - the Eurasian Black Vulture (Aegypius monachus) and the Griffon Vulture (Gyps fulvus). There are nine species of small raptors in the assemblage, including the Eurasian Sparrowhawk (Accipter nisus), the Black Kite (Milvus cf. migrans), harriers (Circus sp.), buzzards (Buteo cf. rufinus), two falcon species and a kestrel (Falco cherrug, F. peregrinus, and F. tinnunculus), and two small owls (Asio flammeus and $A$. otus).

Crows and ravens contribute only $4 \%$ to the total number of bird bones at the site, $2 \%$ in weight. This class is comprised of four species in the genus Corvus (C. cornix, C. corax, C. frugilegus, and C. monedula), and a magpie (Pica pica).

Three other classes of birds associated with water also make minor contributions to the Hallan Çemi avifauna. They include 1) five species of large wading birds, dominated by a very large species of crane (Grus cf. grus), with smaller numbers of herons (Ardea cinerea and A. purpurea), a bittern (Botaurus stellaris) and a stork (Ciconia ciconia); 2) a handful of smaller wading birds, consisting of a stone-curlew (Burhinus oedicnemus), a curlew (Numenius arquata), a stilt (Himantopus himantopus), and a lapwing (Vanellus vanellus); and 3) six species classified here as "water birds" - 
birds of decidedly aquatic habits but that are neither waterfowl nor waders - comprised of a crake (Crex crex), coot (Fulica atra), gull (Larus cf. ridibundus), grebe (Podiceps nigricollis), moorhen (Gallinula chloropus), and a cormorant (Phalacrocorax carbo).

\section{Habitats Exploited}

One of the hallmarks of the Early Holocene sites in the region is that they were strategically located at the junction of a number of near-by eco-zones. It is unclear based on site location alone, however, whether residents took advantage of the variety of resources available to them in these locations and, if so, how. Since birds often occupy very restricted habitats, they present special insight into the diversity of ecozones exploited, the intensity of exploitation, and the distance people traveled to get there.

The Hallan Çemi birds provide solid empirical evidence that Hallan Çemi residents actively exploited diverse habitats both close to home and further away. Based on information about modern bird habitats and behavior in the region (Kirwan et al. 2008), we can assign the various taxa represented in the Hallan Çemi avifauna to specific habitats that include: 1) grasslands; 2) mountains; 3) rocky areas, defined as open arid terrain with scattered vegetation and stones and pebbles; 4) wooded steppe, a transitional zone between forest and grassland); 5) woodlands; and 6) wetlands (Table 3).

Hallan Çemi is situated in the foothills of the southern slopes of the eastern Taurus Mountains on the west bank of the Sason Çayi, a tributary of the Batman River (Peasnall 2000). Today these foothills, marked by rocky outcrops, are covered by the remnants of an oak/pistachio forest, which likely would have been more heavily wooded when the site was occupied (Figure 4). Charcoal data from the site suggest that Hallan Çemi residents had easy access to and systematically exploited both woodland and riverine environments (Nesbitt 1995, Peasnall 2000: 133). More steppic vegetation evidenced in the Hallan Çemi botanical remains was likely encountered in the flatter, more open regions located to the south of the site (Peasnall 2000). Thus, of the six 
habitats represented by Hallan Çemi avifauna, five (grasslands, wetlands, wooded steppe, woodlands, and rocky terrain) could be found either adjacent to the site or in easy walking distance from the site. Mountains, reaching over $2800 \mathrm{~m}$ in elevation, are only about $5 \mathrm{~km}$ from the site.

Grassland environments that served as the habitat for the dominant gamebird species (Grey Partridge and Great Bustard) are best represented of the various ecozones from which Hallan Çemi obtained birds (Table 4, Figure 5a). In addition to gamebirds, Hallan Çemi residents also exploited this habitat for two raptor species, the Short-eared Owl (Asio flammeus) and the Long-legged Buzzard (Buteo rufinus), as well as the Eurasian Stone-curlew (Burhinus oedicnemus) - a small wading species commonly found in grassland areas and sand dunes, and the Rook (Corvus frugilegus).

Wetland environments are also well represented. Obviously wetland areas were the source of all waterfowl species, large waders, most of the small waders, and taxa classified as water birds. Hallan Çemi also exploited this habitat for harriers (Circus aeruginosus), a type of small raptor. Species that inhabit rocky terrain are less well represented, with roughly equal numbers of Chukar (Alectoris chukar) and Eagle-Owl (Bubo bubo) obtained from this habitat, although the Eagle-Owl might be found in other habitats as well. Hallan Çemi residents also took advantage of near-by woodland habitats, primarily for raptors - including the likely large eagle species represented in the assemblage (Aquila sp.), Long-eared Owl (Asio otus), Eurasian Sparrowhawk (Accipiter nisus), and Black Kite (Milvus migrans), along with an occasional Wood Pigeon (Columba palumbus). Wooded steppe habitats are much more poorly represented, with Hallan Çemi residents exploiting this environment for a species of falcon (Falco cherrug) and two species of crow, the Western Jackdaw (Corvus monedula) and the Common Magpie (Pica pica). They may have traveled furthest into more mountainous areas to hunt two large raptor species, Eurasian Black Vulture (Aegypius monachus) and Griffon Vulture (Gyps fulvus), and Peregrine Falcons (Falco peregrinus).

It is possible that Hallan Çemi residents obtained at least some of these species closer to home. Scavenger species like crows and vultures may have been drawn to the 
site to feed on refuse, much the way that a number of commensal mammal species are thought to have done. Raptors, like the Eagle-Owl, may also have been drawn to the site to feed on commensal mammals, especially rodents. If so, scavengers and birds of prey may represent targets of opportunity rather than prey animals sought out in specific habitats. It is then possible that all of the species assigned to mountain habitats (the Eurasian Black Vulture, the Griffon Vulture, and the Peregrine Falcon) were, in fact, captured this way. If this were the case it might explain the apparent absence of the mountain species of Aquila - the Golden Eagle, in favor of the smaller Imperial Eagle, a lowland species that inhabits woodland/wetland border areas. We know, however, from the mammal species in the assemblage (particularly the large wild goats) that Hallan Çemi hunters ventured into more mountainous terrain as well.

\section{Seasonal patterns in avifauna exploitation}

The establishment of small communities during the Early Holocene in the eastern Fertile Crescent is a marked change from the more mobile strategies and more ephemeral camps and special function sites characteristic of the final Pleistocene in this region (Peasnall 2000). These settlements are commonly thought to have been occupied yearround (Bar Yosef and Meadow 1995; Byrd 2005; Kuijt and Goring-Morris, Peasnall 2000). Recently, however, Asouti and Fuller (2013) have challenged this prevailing opinion and proposed that Early Holocene sites across the entire Fertile Crescent are better characterized as "temporally variable nodes of habitation and co-residence rather than as permanent, year-round, sedentary villages". They propose that Hallan Çemi, in particular, was not a fully sedentary habitation site occupied year round as has been argued (Rosenberg and Davis 1992; Redding 2005), but rather served a more specialized function as a gathering place for the practice of periodic, possibly seasonal, feasting and ritual activities that helped cement a sense of shared identity among people following more mobile strategies across a broader region (Asouti and Fuller 2013:324).

Many species of birds follow well-defined seasonal migratory patterns making them an ideal indicator of seasonality in subsistence activities and residency. While 
there may be some variation in the geographic parameters of these movements in the Late Pleistocene/Early Holocene, modern day seasonal patterns in bird migratory behavior still provide the best approximation of these patterns in ancient times (Kirwan et al. 2008). The 51 taxa identified at Hallan Çemi can be separated into four groups: Spring/Autumn Visitors for birds that pass through the region on their way to breeding and wintering grounds, Summer Visitors, Winter Visitors, and Year Round Residents. Within these seasonal groupings, the avifauna can be further classified by the habitats they occupy while in residence (Table 5).

When we examine the proportion of birds by season of residence, it becomes clear that birds were hunted in all seasons, suggesting that at least some people were present at Hallan Çemi year-round (Table 6; Figure 5b). Of the taxa that visit the region on a seasonal basis, winter visitors are especially well represented. Wetland inhabitants, especially geese, are the dominant winter visitors (Figure 5a). Waterfowl are highly social species that form large flocks in the winter and would have predictably provided an abundant winter resource for Hallan Çemi residents.

Summer visitors occupy multiple different habitats (Tables 5-6, Figure 5a). They include three grassland species - a small wader, and two gamebirds, two vulture species found in mountainous regions, four raptors, and a single gamebird species that occupies woodlands, as well as four species of waterfowl, large waders, and water birds from wetland environments. These diverse summer species make it clear that Hallan Çemi residents took advantage of more clement summer weather to forage in a wide range of eco-zones (near-by and farther afield).

Passage migrants flying through the region in fall and spring are limited to one grassland species (an owl, Asio flammeus) and three wetland species, consisting of two small waders (a stilt, Himantopus himantopus and a curlew, Numenius arquata), a heron (Ardea purpurea), and a species of duck (Anas querquedula). Birds belonging to these taxa make up only a small proportion of the Hallan Çemi avifauna. Nonetheless, their presence in the assemblage confirms that at least some Hallan Çemi residents occupied 
the site not only in summer and winter but in at least spring and fall (if not both seasons) as well.

The bulk of the avifauna is comprised of resident species, consisting primarily of grassland species - especially Great Bustard (Otis tarda) and Grey Partridge (Perdix perdix) (Table 6, Figure 5a). While these taxa could, theoretically, be hunted at any season of the year, both the Grey Partridge and the Great Bustard flock together in the non-breeding season (i.e. autumn/winter). The Great Bustard was known, in fact, to congregate in the thousands in the past, especially in bad weather (Cramp 1980; Johnsgard 1991). If Hallan Çemi residents took full advantage of this behavior, this means that the majority of birds consumed were taken from near-by grassland and wetland habitats during winter months when other resources (especially legumes, fruits, and nuts) may not have been as plentiful. Other resident species represent the diverse array of habitats exploited by Hallan Çemi residents, including rocky terrain (the source of Chukars), wooded steppe and woodlands, where four species of resident crows reside, and mountains, home to the Peregrine Falcon.

\section{Changing patterns of avifauna exploitation over time}

Deposits in certain parts of the residential area of the site can be assigned to various building episodes, making it possible to track changes in animal exploitation over time. The most robust of these temporally assigned assemblages come from the final building level ( $B L 1$ ) and $B L 3$, located at about the $2 \mathrm{~m}$ mark of the total $4.3 \mathrm{~m}$ of deposits attested to in the deep sounding in the CAA (Tables S1-S3). Thus the assemblage from these levels represents the later part of the relatively brief approximately 400 year occupation of the site. While deposits in the CAA can be partitioned by depth and roughly correlated with building levels encountered in the residential areas of the site, the smaller size of the assemblage from these deposits analyzed by the Smithsonian team (especially the avifauna from these deposits), as well as the more specialized function of this part of the site discussed below, limits the usefulness of these 
assemblages in gaging changes in every-day diet and subsistence strategies at Hallan Çemi over time.

Looking first at the proportion of birds in the overall assemblage of identifiable bones, one sees a marked, and statistically significant, increase in the importance of birds over time - from $5 \%$ of the total assemblage of identifiable bones in BL 3 to $8 \%$ in BL 1 (Table 1, Table S5). This increase is more impressive when one focuses solely on the small game portion of the assemblage, with the proportion of birds nearly doubling from 10\% in BL 3 to 19\% in BL 1 (Table 7, Table S4). If we partition the small game assemblage into a comparison of "quick" species (birds and hares) and "slow" species (tortoises), over time we see an increase in both birds, and, to a much lesser extent, hares, and a corresponding decline in tortoises (Table 8, Table S6, Figure 6a). Such an increase is commonly interpreted as a sign of localized resource pressure in which easy to catch, but slow to reproduce, game such as tortoises becomes scarcer, resulting in an increased focus on harder to catch quick game, such as birds and hares that are more resilient to hunting pressure (Munro 2004; Stiner et al. 2000). While some impact on local resource availability over the several hundred year occupation of this small site is indicated, it is important to note that tortoises still made a major contribution to the diet of $B L 1$ residents, contributing up to $67 \%$ of the quick and slow small game from $B L$ 1 (Table 8), 50\% of the total BL 1 small game assemblage NISP (Table 7), and an impressive $21 \%$ of the overall BL 1 assemblage (Table 1). Clearly several hundred years of human predation on these animals did not result in a crash in local tortoise populations. Another commonly used indicator of resource pressure is the proportion of small game relative to large game species, with increases in lower return small game interpreted as a response to declines in availability of higher ranked large game species on a more regional basis (Munro 2004; Stutz et al. 2009). This index fails to show any sign of resource pressure over time at Hallan Çemi, where there is a small, but statistically significant (Table S5), increase in the proportion of large game (artiodactyls and large carnivores) relative to small game from BL 3 to BL 1 (Table 7, Figure 6b). 
Several significant temporal trends within the avifauna have bearing on the evolution of subsistence strategies and the nature of anthropogenic impacts on local environments over the occupation of the site. One of the most striking is the decline in waterfowl species. Although the proportion of large waterfowl among waterfowl species remains fairly constant (Table 2 , Table S7, Figure 7a), when compared to the overall avian assemblage, large waterfowl (i.e., geese) show a sharp decline through time $-26 \%$ of the overall number of bones in the avifauna assemblage in BL 3 to $19 \%$ in BL 2 (Table S2), and from 32\% to 19\% in weight, again taken as a rough proxy for meat contribution (Table S3). The importance of the various duck species (small waterfowl) utilized also declines through time as well, but to a much less significant extent, from $10 \%$ of the total avifauna assemblage of BL 3 to $6 \%$ in BL 1 (Table S2). Other wetland species do not show similar declines. Since geese are migratory it is possible that disturbances (human or otherwise) on their breeding grounds could have led to fewer geese arriving at Hallan Çemi for the winter. Hunting pressure from Hallan Çemi residents might also have caused geese to avoid the area around Hallan Çemi when choosing their wintering grounds without causing any overall declines in goose populations.

In contrast, the importance of gamebirds increases over time (Table 2a) especially when contrasted to waterfowl (Figure 7a). There is no corresponding increase in the contribution of gamebirds in weight, however (Table $2 b$ ). This is because there is an equally dramatic, and statistically significant, shift in the gamebird species composition (Table 2a, Table S7, Figure 7b). In BL 3 Great Bustard is nearly one and a half times more common than Grey Partridge. This relationship completely reverses by BL 1 where the Grey Partridge is more than one and half times more common than the Great Bustard. It is possible to read the decline in Great Bustard relative to Grey Partridge as another sign of localized resource pressure due to human hunting. Both grassland denizens, these two species present contrasts in returns and sustainability similar to that proposed for fast and slow small game animals. The Great Bustard is the largest bodied volant bird species, with males ranging from 6 to 18 kilos and females 
between 3 to 3.5 kilos. Owing to its weight, the bustard is more likely to try to run away from predators than to take flight (Cramp 1980). This behavior, coupled with its abovementioned preference for congregating in large flocks (especially in the winter), would have made the Great Bustard a very attractive, high yield prey choice for Hallan Çemi residents. The Grey Partridge, in contrast, is much smaller (averaging .1 kilo), and, although also likely to congregate in large groups, is more likely to take flight when pursued (Johnsgard 1988), making it a less desirable target than the Great Bustard. However, the Great Bustard is slow to reproduce. Females do not typically breed until they are 5 to 6 years old and lay only 2 to 3 eggs per clutch (Johnsgard 1991). The Grey Partridge (like the hare) is a more prolific breeder, reaching sexual maturity at one year and producing 15 to 17 eggs per clutch (Johnsgard 1988). It is easy to see then that Great Bustard populations would be less likely to be able to sustain several hundred years of concentrated hunting, while the Grey Partridge, though not as high yield and easily caught game species, would have been much more resilient.

Another significant trend over time within the gamebird species is the decline of Chukar relative to Grey Partridge (Table 2, Table S7, Figure 7c). The shift in the utilization of these two resident small game birds - with similar returns, degrees of difficulty in capture, and reproductive rates - may have more to do with a shift in the degree to which Hallan Çemi residents exploited the rocky terrain habitats occupied by the Chukar in favor of grassland habitats inhabited by the Grey Partridge. Further, it may also reflect the different behavior of these two species. Chukar can range up to $5 \mathrm{~km} \mathrm{a}$ day, while the Grey Partridge is less inclined to move about, especially in winter, with mobility of about one kilometer or less (Johnsgard 1988). It is thus possible that the prolific and easier to locate and catch Grey Partridge in nearby grasslands became preferred prey over time, while their more ambulatory cousins in less welcoming terrain may have been better able to avoid Hallan Çemi hunters.

It is also interesting to note that there is a marked (though perhaps due to small sample sizes not statistically significant) decline in eagles relative to Eagle-Owls through time (Table 2, Table S7, Figure 7d). The reason or reasons behind this shift are unclear. 
Both taxa lay roughly the same number of eggs per clutch and have similar chick survival rates. Moreover, if the eagle species represented at Hallan Çemi is indeed the Imperial Eagle, both taxa could be found in habitats relatively close to the site (i.e. rocky terrain and woodland/wetland borders). It is also possible that both were drawn to the site to feed on commensal mammals. Eagle-Owls, however, seem to have decreased sensitivity to human presence and practice more opportunistic and adaptable hunting behaviors (Voous 1989). These behaviors may have made them more likely targets for Hallan Çemi hunters, while the eagles may have responded to human hunting with increasingly greater avoidance behaviors over time (Heredia 1996). Given the apparent primarily symbolic role of raptor species discussed below, however, it is also possible this shift is related to some change in the importance of these two taxa in Hallan Çemi cosmology. Seasonal patterns of avifauna exploitation, in contrast, are relatively steady (Table 6, Table S8). Representation of resident species does increase somewhat over time, due primarily to the increased importance of the resident Grey Partridge and the decline of waterfowl winter visitors (Table 2). Once again, however, while Grey Partridges would have been available year round, their habit of congregating during winter months makes it possible that these birds were a special focus of winter resource procurement. If so, their increased importance over time might be seen as helping compensate for declines in the contribution of waterfowl wintering in the region to the Hallan Çemi diet, although it would have taken a lot of these small bodied birds to make up for the decline in the number of higher meat yield geese.

There is no change, however, in the proportions of seasonal visitors to the site that might indicate changing patterns of seasonal occupation of the site over time (Table 5, Table S8, Figure 5b). Winter visitors always dominate among non-resident seasonal species, with statistically equivalent proportions of summer visitors and passage species represented in the assemblages of both $B L 3$ and $B L 1$. This means that reaching back at least as far as the construction of $B L 3$, Hallan Çemi was occupied on a more or less permanent basis throughout the year. Thus the avifauna joins botanical evidence for site occupation from late spring to early autumn and seasonal growth rings 
in clam shells that point to their harvest during both slow and rapid annual growth phases (Rosenberg et al. 1998: 34) to argue for year round occupation of the site.

\section{Symbolic and social role of birds at Hallan Çemi}

Changes in residency patterns and subsistence strategies in the Early Holocene must have had profound implications for social relations within the newly established communities of the eastern Fertile Crescent. For millennia small bands of people moved across the landscape, coalescing and dispersing at different seasons of the year, with the option of leaving the band and striking out on one's own a viable, perhaps preferable, alternative to working out intra-group disputes. Now these groups established more or less year round residence in a single location, exploiting diverse resources available within more tightly defined catchment areas. Moreover, there is growing evidence for increased manipulation of these local environments and the biotic communities within them to enhance the productivity and predictability of resource returns needed to support these more established communities (Asouti and Kabukcu 2014; Asouti et al. 2015; Riehl et al 2015). This narrowing in catchment areas and the increased investment of landscapes and resources within them carries with it real potentials for uneven returns, the development of proprietary notions over resources and the means of producing them, and concerns about free riders taking advantage of collective effort - all of which would threaten an egalitarian ethos based on balanced reciprocity likely to have prevailed in earlier times (Zeder 2016).

It should come as no surprise, then, that Early Holocene communities across the entire Fertile Crescent show evidence of an increasing emphasis on social and ritual behaviors aimed at navigating these new challenges. From the communal buildings at Jerf el Ahmar in the western Fertile Crescent (Stordeur et al. 2000), the large "tower" of Jericho in the southern Levant (Bar Yosef and Meadow 1995), and the monumental " $T$ " shaped pillars and their elaborate animal imagery at Göbekli Tepe in the east (Schmidt 2012), Early Holocene communities show increasing evidence for the conduct of a range 
of social and ritual activities directed at reinforcing and perpetuating a sense of community and shared identity.

There are also a number of indications of increasing complexity in social organization and elaboration of social and ritual mechanisms at Hallan Çemi, probably intended for promoting community cohesion. As noted earlier, two large Building Level 1 houses in the southwestern portion of the site (Figure 2) have been interpreted as serving some sort of extra-household community-wide function (Rosenberg et al. 1998; Rosenberg and Redding 2000:185). Between 5-6 m in diameter, these structures are almost three times the size of other BL 1 structures and substantially larger than structures in earlier building levels - with the possible exception of House $F$ in $B L 2$, a potential precursor to these BL 1 community houses (Rosenberg and Redding 2000: 46). Unlike other structures, these large houses are each set into a pit with walls constructed of sandstone slabs interspersed with spaces that must have held roof supports. They also had carefully prepared floors, central plastered hearths, and semicircular stone benches against the wall (Peasnall 2000; Rosenberg and Redding 2000: 44). Although largely devoid of plant and animal remains and ground stone food processing implements, they did contain exotic materials, including the largest obsidian blade core found at the site and the only evidence for obsidian knapping at the site. Fragments of copper ore (thought to have been used as pigment) were found in or near these structures, but nowhere else. As mentioned above, House A contained a complete aurochs skull with no associated mandible. The skull was found upside down by one wall facing the entrance to the house, as if it had been hung on the wall before falling to the floor. Inside the other large house, House B, excavators found three male sheep skulls and several red deer antlers. Fragments of chlorite stone bowls, some decorated with incised or bas-relief geometric and naturalistic motifs, were found in some numbers throughout the site, along with chlorite pestles or batons (some with sculpted animal heads as handles) thought to have been used in association with these bowls (Rosenberg et al. 1998: 29). Evidence of careful curation of the bowls speaks to their importance, possibly, it is speculated, in formalized contexts such as feasting. The large 
central activity area - with its quantity of fire cracked rocks, articulated portions of ungulate carcasses, and aligned sheep skulls - is further hypothesized to have been the site of community-wide feasting at Hallan Çemi (Rosenberg et al. 1998: 30; Rosenberg and Redding 2000: 58). What, then, can the avifauna assemblage from Hallan Çemi add to the evidence for social relations and ritual activities at the site? As it turns out, quite a bit.

Comparing the overall composition of the faunal assemblages from residential areas to those from the CAA, we see both a marked reduction in the diversity of animal in the CAA assemblage as well as a marked emphasis on larger species. Not only are birds less common in CAA deposits (at $2 \%$ compared to $6 \%$ in residential areas), all small game animals are significantly less well represented here than in residential areas of the site (16\% compared to $41 \%$ ) (Tables 1 and 7, Table S5). The narrowed focus on large game animals in the CAA also sees an increased emphasis on caprines - especially an extraordinarily large variety of wild goat, as well as an increase in wild boar, both at the expense of red deer. While always poorly represented at the site, wild cattle are also more common in the CAA than in residential areas. There is also a marked increase in the representation of bears, from $20 \%$ of the carnivore remains in residential areas to nearly $30 \%$ in the CAA (Table 1). While there are some variations in the proportions of various species through time in CAA deposits, an emphasis on large game animals and reduced species diversity is a consistent feature of CAA deposits when compared to roughly contemporary deposits in residential areas (Tables 1 and 7).

Perhaps even more striking, however, is the major change in the composition of the CAA avifauna assemblage compared to that from the residential area (Table 2, Table S7). While gamebirds make up nearly $50 \%$ of the birds from residential areas, in the CAA they are only $36 \%$ of the assemblage. Raptors, on the other hand, soar from $15 \%$ of the avifauna from residential areas to $33 \%$ in the CAA. In keeping with the CAA's emphasis on large game animals, there is also a marked, and, in most cases statistically significant, emphasis on the larger taxa within each of the general classes of birds examined here (Table 2a, Table S7). Great Bustard dominates CAA gamebirds (Figure 8a); geese make 
up $95 \%$ of the CAA waterfowl (Figure 8 b); the Common Crane is much better represented in the CAA than in residential areas (though perhaps owing to smaller sample size this difference is not statistically significant) (Table S7, Figure 8c). Within raptors, large raptors, especially eagles, dominate in the CAA (Figure 8d). Hawks, falcons, and harriers and other small raptors, in contrast, are poorly represented in the CAA. Once again these contrasts between the avifauna assemblages in these two parts of the site are consistent over time (Table 2), although the smaller sample sizes of avifauna assemblages from CAA deposits makes it difficult to judge the significance of these patterns.

The differences between the residential and CAA assemblages cannot be attributed to differences in recovery practices in different areas of the site. Due to the salvage nature of the excavations, conducted under considerable time pressure and sometimes perilous circumstances in a politically unstable part of Turkey, excavators elected to screen only $25 \%$ of deposits. But this practice was followed in all areas of the site, not just in residential areas. Nor can these differences be attributed to household refuse management, as might be the case if the CAA represented larger more conspicuous butchery and consumption waste removed from household contexts. There are several lines of evidence that argue against this possibility. First, while the larger communal houses are reported to have been relatively free of food preparation refuse, this cannot be said of residential areas in general; BL 1 contexts alone yielded 42,500 animal bones (including both identifiable and unidentifiable fragments). Moreover, although smaller game animals are indeed better represented in residential areas, large fragments of large game animals are plentiful here as well. While future work will examine part distribution and bone fragmentation further, the similarity in the average fragment weights of wild boar elements from these two areas of the site ( $13.5 \mathrm{~g}$ per fragment versus $12.1 \mathrm{~g}$ per fragment in the CAA) does not support the hypothesis that residential areas contained smaller refuse overlooked when removing more obvious carcass parts to a central midden area. Comparison of the average fragment weights for individual avian taxa (Table S4) are generally within a few tenths of a gram of one 
another, showing no suggestion of gross disparities in fragment size that might be indicative of such practices. The difference in the composition of large game representation between the CAA and residential areas, which sees red deer decline and caprines (especially goats) and boars increase, also indicates that these differences cannot be attributed solely to size sorting in disposal practices. Even more persuasive perhaps is the reorientation of the CAA avifauna in which raptors are more than twice as common as they are in residential contexts and almost as well represented as gamebirds (Table 2a). Thus while assemblages in these two different sectors of the site were likely subject to different post-depositional taphonomic factors, the body sizeindependent differences in taxonomic composition between the CAA and residential assemblages indicate that they are not merely sub-sets of the same range of processing and consumption behaviors at the site. Instead, they are more likely to represent different types of activities practiced at the site that involved both food and non-food related activities.

In fact, the CAA assemblage conforms well to Jackson and Scott's (1995) expectations for faunal refuse from feasting contexts. Developed originally for emergent complex societies in the southeastern US, but more widely applicable to feasting contexts in general, these expectations include: 1) low sample diversity, 2) high meat yield species, 3) bulk meat cuts, 4) bulk cooking (e.g., roasting), and 5) little butchering debris. Of these indices, the CAA assemblage clearly conforms to the first two in its lower species diversity and emphasis on high meat yield taxa. The large articulated carcass portions found in the CAA and the plentiful fragments fire-cracked rock in these deposits can be read as indications of the roasting of bulk meat cuts meeting the second two of the Jackson and Scott feasting indices. CAA deposits also meet a number of Twiss's material correlates of ethnographically and ethnohistorically documented aspects of feasting (Twiss 2008:420-422). These include large dense concentrations of food remains, tremendous quantities of trash, remains of large and possibly dangerous animals (with wild cattle singled out as a particularly likely feasting food), discard of articulated joints, numerous large cooking facilities, and unusual quality of serving 
equipment (if the chlorite bowls and batons are associated with activities conducted here), and a discrete physical setting.

Ethnographic evidence points to the higher value of meat from hunted animals that imbues them with powerful symbolic value over gathered resources like small game and plant resources, and thus makes them more likely component of feasting activities that carry important social messages (Kent 1989). The communal sharing of meat from large animals is then an effective way of converting perishable "material storage" into "social storage" (Twiss 2008:423) - a means of cementing social relations and obligations within a community. A strong case can, thus, be made that the CAA served as an important locus for feasting on the meat of hunted large, and in some cases ferocious (i.e. boars, bears, and aurochs), animals taking on a special symbolic importance in conveying significant social messages to feast participants.

It is also important to note that the symbolic value of animals goes beyond the nutrition they provide, and extends to their connection to higher order cosmological principles that imbue them, and pieces of them, with special meaning (Jackson and Scott 1995). In many cultures certain species of birds figure prominently in cosmology and associated symbolic repertoires, with body portions associated with flight and, in some cases, ferocity particularly potent symbols. Examining skeletal element distributions in avifauna assemblages has proven a productive avenue for detecting the role of birds in ancient cosmology (e.g., Kelly 2010; Kristensen and Holly 2013; Scalf 2012). Meat bearing portions of birds are confined to the trunk and the legs, and their presence in sites reflects directly on consumption, which may in certain contexts carry symbolic meaning. Skulls, wings, and foot elements, on the other hand, provide little or no usable meat, but can be visually striking - especially the flight feathers from the wing elements of larger birds and the claws of raptors and crows. In fact, a number of studies of avian faunal assemblages from Late Pleistocene/Early Holocene sites in the Near East have used differentials in avian skeletal element representation to argue that certain taxa and certain parts of certain taxa - carried special symbolic meaning and played important roles in ritual activities conducted at these sites (Gourichon 2002; Gourichon 
and Helmer 2004; Martin et al. 2013; Recchi and Gopher 2002; Russell and McGowan 2003; Simmons and Nadel 1998; Solecki and McGovern 1980). A similar argument can be made for the Hallan Çemi avian assemblage.

Table 9 provides a breakdown of elements in a bird skeleton into five regions: skull, trunk, legs, wings, and feet. Since the number of bones in a bird skeleton can vary depending on taxa, the Accipitridae family (diurnal raptors) - which lacks repeated cervical vertebrae and a notarium - was chosen as the standard. A mounted skeleton of a Bald Eagle (Haliaeatus leucocephalus) was used as a reference. The general proportions of each body part region computed using this standard, however, should be generally consistent among all avian taxa. Comparing the distribution of elements of various taxa, and taxonomic groups, to the distribution of these elements in a standard bird skeleton makes it possible to identify differentials in body part representation in an assemblage. Distributions matching that of the standard can be used to argue that whole carcasses were not only brought back to a site and deposited there, but also preserved over time and recovered in excavations. Departures from this standard might be attributed to a number of different factors - from post-depositional loss or lack of recovery of smaller elements to actual differences in ancient human behavior in the transport and treatment of these different parts for both consumption and non-food related purposes.

None of the body part region distributions for the various classes of birds at Hallan Çemi match the standard distribution of elements in a complete bird carcass (Table 10; Figure 9, Table S9-12). Elements from the skull region are for the most part absent - possibly a reflection of the greater fragility of skull bones, but also a possible indication that the heads of birds were generally removed before they were brought back to the site. Large gamebirds (i.e., Great Bustard) come closest to matching the distribution of a complete skeleton from the standard, although they show a statistically significant emphasis on meat-bearing trunk and leg elements. Interestingly this emphasis is even more strongly expressed among bustards from the CAA (Table 11, Table S11, Figure 10a) - a possible indication that more or less complete carcasses of 
these large birds were brought to the site, butchered and consumed in residential areas, with meaty portions of some of these birds transported to the CAA as part of the feasting activities conducted there.

Small gamebirds (i.e., partridges) and, to a lesser extent, small waterfowl (i.e., ducks), both show an emphasis on meat bearing portions at the expense of non-meat bearing elements (Figure 9), and, for small gamebirds at least, this is true in both residential areas and in the CAA (Table 10). Tchernov (1994) found a similar body part distribution among ducks from the Early Holocene site of Nativ Hagdud in the southern Levant, which he attributed to a practice of field dressing that left behind non-meat bearing parts (skulls, feet, and lower portions of the wings) where the birds were killed. A parallel pattern is noted by Gourichon (2002) for both ducks and partridges at Jerf el Ahmar in the northern Levant. While this pattern may indeed be a reflection of differential transport for these birds, the under representation of some of these elements (i.e., the phalanges of the lower wings and feet) may be attributable to poorer preservation and recovery, especially at sites like Hallan Çemi where deposits were only partially screened.

The body part representations of other taxonomic groups at Hallan Çemi are dramatically different from the emphasis on meaty regions seen among large and small gamebirds and small waterfowl (Table 10, Table S12, Figure 9). Wing elements are more than twice as well represented among large waterfowl than they are in the standard (33\% compared to $15 \%$ ). This pattern is repeated in both areas of the site, but is especially strong in the CAA (Table 11). It is also interesting to note that wing elements make up nearly half of the large number of goose bones recovered from within House $B$, one of the two "communal" houses in BL 1 (Table 10 and S2, Figure 10b). In contrast, goose wing elements are only $6 \%$ of goose bones recovered from within other BL 1 houses. It is possible to speculate that goose wings adorned with flight feathers figured prominently in the activities associated with this postulated communal structure.

Among the large waders (principally comprised of Common Crane), both foot and wing elements are over represented compared to the standard. Cranes are 
frequently represented in the bas-relief carvings on the " $T$ " shaped pillars at Göbekli Tepe, interpreted as an indication of their importance in the iconography of the Early Holocene people of the eastern Fertile Crescent (Peters and Schmidt 2004). The presence of an articulated crane wing (from the distal humerus to the apical phalanges) in special context at Çatalhöyük, along with wall murals at the site depicting what are likely cranes engaged in a mating dance, leads Russell and McGowan (2003) to wonder whether crane wings were part of costumes worn during ritual performances. A similar function for both the wings of cranes and geese might be postulated at Hallan Çemi.

Raptors, large and small, and crows show the greatest departure from the standard (Table 10, Table S12, Figure 9). Meaty parts from these taxa uniformly contribute less than $10 \%$ of the elements of these birds (compared to $55 \%$ in the standard), with an emphasis on wings in small raptors and crows and an emphasis on feet in large raptors (Table 10, Figure 9). Of the two most numerous large raptors, meaty elements and wings are better represented in Eagle-Owls, while nearly $80 \%$ of the eagle elements are foot bones - especially pedal and ungual phalanges (Figure 10c, Table S9). Talons of these two birds are quite large and dangerous looking (Figure 11), and both the Eagle-Owl (Bubo bubo) and the likely eagle species represented at Hallan Çemi, the Imperial Eagle (Aquila heliaca), have exceptionally large wing spans (up to 1.8 $\mathrm{m}$ to $2 \mathrm{~m}$ respectively) with distinctive flight feathers. Talons of smaller raptors and crows may be somewhat under represented due to the smaller size of their pedal phalanges, but the emphasis on wings of these species and the almost total absence of meaty elements strongly points to a non-food, likely symbolic role of these animals.

The symbolic role of raptors, especially the feet and wings of large raptors, seems widespread throughout the Fertile Crescent. Raptors make up 18\% of the large and diverse avifauna from Ohalo II, a semi-sedentary base camp occupied during the Late Glacial Maximum (c. 23,000 kya) in the southern Levant (Simmons and Nadel 1998). As at Hallan Çemi, non-meat elements of raptors, especially feet and claws of large raptors, are significantly better represented than in gamebirds and waterfowl (c. $40 \%$ in birds of prey versus c. $10 \%$ or less in non-raptors). Another indication of the symbolic 
value of raptors in Epipaleolithic ideological systems of the southern Levant is the inclusion of a Golden Eagle wing bone in what has been identified as a "shaman" burial at the Natufian (c. 12,000 BP) age site of Hilazon Terrace (Munro and Grosman 2010). Early Holocene Nativ Hagdud shows a continued emphasis on the claws of raptors that is especially strongly expressed in eagles (Tchernov 1993:25), a pattern that Tchernov, and Pichon (1985) before him, suggested might be attributed to the use of these elements as tools. This interpretation is questioned, however, by Gourichon (2002), who argues that the over representation of wing and foot elements of Griffon Vulture at contemporary Jerf el Ahmar is more likely attributable to their use as "ornaments or symbolic trophies". Martin et al. (2013) recently published an article on the avifauna from Wadi Jilat, another roughly contemporary Early Holocene site in the eastern Jordan steppe, which is dominated by raptors, eagles in particular. Interestingly, unlike other southern Levantine sites, wing and foot elements are conspicuously under represented here, leading Martin et al. to suggest that raptors were processed here with elements that carried high symbolic value - wings and feet - "removed for use elsewhere" perhaps for "onward trade and exchange" (Martin et al. 2013: 661).

More evidence of the symbolic importance of raptors can be found closer to Hallan Çemi in other Early Holocene communities of the eastern Fertile Crescent. Excavations at Zawi Chemi Shanidar, a roughly contemporary (c. 11,600 BP) Early Round House community located in northeastern Iraq, recovered wing bones from a number of large raptor species in a pit located outside the walls of the only stone structure encountered in the relatively limited exposures at the site (Solecki and McGovern 1980). Initially identified by Alexander Wetmore as belonging to two species of vulture (the Bearded Vulture, Gypaetus barbatus and the Griffon Vulture, Gyps fulvus), two eagle species (the White-tailed Eagle, Haliaeetus albicilla and an unidentified small eagle species) and the Great Bustard (Otis tarda), these bones have been subsequently reanalyzed by Spitzer. The 172 bones Spitzer identified from the site were almost exclusively (93\%) wing elements of large raptors, nearly half (46\%) of which were identified as White-tailed Eagle. Other significant contributors were a species of Aquila 
eagle, the Bearded Vulture, and the Osprey (Pandion haliaetus). The Eurasian EagleOwl, Great Bustard, Grey Partridge, Chukar, a heron (Ardea cinereus), and a species of goose (Anser sp.) were found at the site in very small numbers (5 elements or fewer). Also found in the pit containing large numbers of raptor wings were the skulls of at least 15 large caprines that Zeder has identified as belonging primarily to an exceptionally large variety of wild goat - similar in size to the large goats found in the CAA and other locations at Hallan Çemi. Together, the Zawi Chemi remains from this pit reinforce that idea that the central area of these Round House communities served as the locus of ritual feasting and performance.

Sites dating to a later phase of this Round House tradition in the eastern Fertile Crescent (c. 11,400-11,500 BP) show a continued - if not amplified importance of raptors and other birds in the symbolic repertoire of the region. At Qermez Dere, a Late Round House site located in more steppic regions of northern Iraq, the various large raptors in the avifaunal assemblage are represented almost exclusively by foot elements (Dobney et al. 1999). Although the avifauna from Nemrik, another Late Round House site located in northern Iraq, remain unpublished, a number of stone batons were recovered that resemble batons found at earlier Hallan Çemi. While the batons at Hallan Çemi were topped by stylized heads of caprines and other mammals, many of the Nemrik batons were topped by clear representations of raptor heads (Kozlowski 1989). In addition to the depictions of cranes in glyptic art mentioned earlier, moreover, excavations at the famous ritual center of Göbekli Tepe recovered a beautifully rendered stone figurine of a vulture (Peters and Schmidt 2004). Other depictions of vultures in contemporary or slightly later contexts in the Near East have been found at Nevalı Çori (Hauptmann and Schmidt 2001), Jerf el Ahmar (Stordeur 2000), and in wall paintings at Çatalhöyük (Russell and McGowan 2003).

A strong case can thus be made that the wings of geese and cranes and the wings and feet of raptors and crows - especially the feet of large raptors - carried potent symbolic value for Hallan Çemi residents. As Twiss (2008) notes, feasting is often marked by performances, often charged with ritual meaning, in which performers wear 
costumes or manipulate objects of special symbolic importance. The higher proportions of raptors in the CAA and the stronger representation of wings and feet of these taxa in this central area, as well, perhaps, as the over representation of goose wing bones in one of the two proposed communal houses, suggests that display of these elements (or the feathers associated with them) may have been part of such performances. If so, these remains meet even more of the ethnographically documented material correlates of feasting identified by Twiss - remnants of costumes, symbolically charged ornaments, and trophy bones (Twiss 2008: 421). It seems then that Hallan Çemi residents both embraced and helped perpetuate a symbolic repertoire shared by people across the Near East stretching back at least as far as the Late Pleistocene and that still shaped the world view of people in this broad region many millennia after the abandonment of this small community.

\section{Implications of Hallan Çemi avifauna for broad spectrum communities}

Although birds played a relatively minor role in the subsistence of Hallan Çemi residents, the avifaunal assemblage from this site provides special insight into many different aspects of the lives of this small Early Holocene community. These insights, in turn, add to the growing understanding of the similar communities that sprang up across the Fertile Crescent at this time, the broad spectrum economies that supported them and served as the incubators for initial domestication of key crop and livestock species, and the evolution of social and ritual mechanisms that provided a sense of shared corporate identity and community cohesion. In particular, they allow us to address some of the key differences between contrasting explanatory frameworks that have been offered to account for the dramatic changes in settlement patterns, land-use patterns and impacts, subsistence, and ritual activity that occurred during this pivotal period.

The Hallan Çemi avifauna confirms that residents of the site took advantage of its strategic location exploiting the diverse wetland, grassland, woodland, and upland environments within easy reach of the community. It provides definitive evidence that for much, if not all of its existence, the site was occupied year round, and that residents 
took strategic advantage of seasonal availabilities of different resources to cobble together a stable subsistence economy capable of supporting this small community throughout the year. Shifting proportions of avifauna within the overall Hallan Çemi assemblage, and, especially, changes in species representation within the avifauna assemblage over time show that the long-term exploitation of these environments had consequences - particularly on species unable to rebound from sustained human hunting, or those that developed avoidance behaviors as a response to human predation. But they also show that these localized impacts did not result in an overall decimation of local resources. Instead, Hallan Çemi residents made adjustments to subsistence strategies that replaced depleted resources with alternative, more resilient ones that could be more sustainably harvested.

Thus, rather than responses to population packing and demographically induced resource pressure as some have argued (Stiner 2001; Stutz et al. 2009), the picture emerging from Hallan Çemi supports an alternative scenario. People across the Fertile Crescent seemed to capitalize on new opportunities afforded by Early Holocene climatic amelioration. They targeted specific locations where abundant and diverse resources could be found within well-defined catchments. They took advantage of their increasingly well-honed ability to predictably locate and extract resources within these environments. They used their expanding sets of ecological knowledge about these environments to manipulate biotic communities in ways that increased the yield and reliability of key resources. In so doing they constructed subsistence strategies that yielded a secure, year-round resource base, allowing these small communities to remain together for longer periods of time. To say that these are semi- to fully sedentary communities of some permanence is not to mistake them for "permanent, year round, sedentary villages" on a par with later village communities supported by fully developed agricultural economies as Asouti and Fuller fault other researchers for doing (2013:314, emphasis added). A more apt characterization would see these as communities of complex hunter-gatherers that intensively exploited resource rich areas in a way that took advantage of the greater bounty of Early Holocene environments, while at the 
same time buffering these communities from the more marked seasonality in resource availability of these environments and the periodic (decadal to centennial) climatic fluctuations experienced during the first 1000 years or so of the Early Holocene (Asouti in press). Increasing investment in these environments and more intensive efforts at enhancing their biotic productivity and predictability were aimed at protecting this investment. While doing so, these efforts set into motion co-evolutionary relationships between people and economically important species that, for some, resulted in their domestication and, several millennia later, the development of village communities supported primarily by the production and consumption of domestic crops and livestock (Zeder 2011).

Finally, and perhaps most importantly, the Hallan Çemi avifauna provide a unique window into a growing investment in feasting and ritual activity that helped bind this community together over the 400 or so years of its existence. In addition to highlighting the substantial differences between quotidian diets of residential areas and feasting foods evidenced in the CAA, a strong case can be made that certain species and certain parts of birds played an important role in the increasingly more elaborate ritual activities practiced by Hallan Çemi residents both in the context of these feasts and more generally.

Brian Hayden (1995:296) cited Hallan Çemi as support for his thesis that competitive feasting served primarily to advance social inequality within cultures on the threshold of plant and animal domestication. A far better case, however, can be made that feasting in these Early Holocene communities played a more integrative role in smoothing over potentials for inequalities likely to arise with increased investments in the manipulation and extraction of resources from more narrowly defined catchments areas - both at Hallan Çemi (Rosenberg and Redding 2000) and more broadly (Kuijt 2000; Twiss 2008). That said, it should be noted that while serving this broader integrative, leveling role, feasts may at the same time confer some social and political capital on hunters that contribute to them, or to households that host them, thereby creating another plane of tension between the egalitarian ethos that defined these 
communities and the various forces fostering inequalities that threatened this ethos (Dietler 2001; Twiss 2008).

There is a great deal of variability in the importance afforded to such activities in different explanatory scenarios for the emergence of broad spectrum economies and the domesticates that eventually arose from them. While many of these scenarios seem to relegate changes in social organization and ritual activity to more or less tangential roles as knock-on side effects of the sweeping changes in environment and economy, others award these changes a primary catalytic role in these developments while downplaying or discounting other possible shaping factors (see Zeder 2012b, 2015, 2016 for a discussion). The Hallan Çemi avifauna reinforce the emerging impression that social, ritual, ecological, and economic factors worked together in Early Holocene broad spectrum communities to promote equally important overarching goals of preserving community cohesion and longevity, while also creating a secure and predictable resource base needed to support the community. Attempts to disarticulate these forces and to credit one or the other to a primary role in these developments are bound to come up short.

\section{Conclusions}

Thus the Hallan Çemi avifauna, like avifauna assemblages from other Early Holocene sites in the region, provide key insight into the core features responsible for the establishment, maintenance, and, evolution of these communities into the agriculturally based societies that followed them. They speak to the environmental context of these small communities, their ability to exploit the mosaic of environments created by Early Holocene climatic change to their advantage, and their impact on these environments. They also speak to the degree of permanence of these communities and how they dealt with the increased seasonality of Early Holocene environments and the fluctuations in resource availability that went along with marked variations in seasonality. And they give a special window into the mechanisms occupants of these communities used to navigate the challenges arising from living together on a more permanent basis while 
exploiting more narrowly defined catchment areas in increasingly intensive ways. Most importantly they show how the social, ritual, economic, and ecological facets of the lives of the people came together to both perpetuate and reshape these communities on the threshold of domestication and the emergence of agriculture.

\section{Acknowledgments}

This research was supported by funding from the Wenner Gren Foundation for Anthropological Research (Gr. 8619), The National Geographic Society (CRE Grant Number: 9313-13) funded by the Smithsonian Institution Scholarly Studies Program. The authors thank Richard Redding, Michael Rosenberg, Bruce Smith and Reuven Yeshurun for helpful comments. And Hanneke Meijer for providing photographs of specimens at the Senckenberg Natural History Museum.

\section{References}

Asouti, E. in press. Human palaeoecology in Southwest Asia during the early Pre-Pottery Neolithic (9700-8500 cal BC): the plant story, in M. Benz, H.G. Gebel, \& T. Watkins (ed.) Proceedings of the $9^{\text {th }}$ ICAANE Workshop "The Construction of Neolithic Corporate Identities. SENSPSE 18, Berlin: ex oriente.

Asouti, E. \& D.Q. Fuller. 2013. A contextual approach to the emergence of agriculture in Southwest Asia. Reconstructing Early Neolithic plant-food production. Current Anthropology 54: 299- 345.

Asouti E. \& C. Kabukcu. 2014. Holocene semi-arid oak woodlands in the Irano-Anatolian region of Southeast Asia: Natural or anthropogenic? Quaternary Science Review 90: $158-82$.

Asouti , E., C. Kabukcu, \& C.E. White. 2015. Early Holocene woodland vegetation and human impacts in the arid zone of the southern Levant. The Holocene 
doi:10.1177/0959683615580199

Bar-Yosef, O. \& R.H. Meadow. 1995. The origins of agriculture in the Near East. In T.D.

Price \& A.-B. Gebauer (eds.) Last hunters, first farmers: new perspectives on the transition to agriculture: 39-94. Santa Fe: School of American Research Press.

Byrd, B. 2005. Reassessing the emergence of village life in the Near East. Journal of Archaeological Research 13: 231-90

Cauvin, J. 2000. The Birth of the gods and the origins of agriculture. Cambridge: Cambridge University Press.

Cramp, S. (ed.). 1977. Handbook of Birds of Europe, the Middle East, and North Africa: the Birds of the Western Palearctic, Vol. 1, Ostrich to Ducks. New York: Oxford University Press.

Cramp, S. (ed.). 1980. Handbook of Birds of Europe, the Middle East, and North Africa: the Birds of the Western Palearctic, Vol. 2, Hawks to Bustards. New York: Oxford University Press.

Cramp, S. (ed.). 1983. Handbook of Birds of Europe, the Middle East, and North Africa: the Birds of the Western Palearctic, Vol. 3, Waders to Gulls. New York: Oxford University Press.

Cramp, S. (ed.). 1985. Handbook of Birds of Europe, the Middle East, and North Africa: the Birds of the Western Palearctic, Vol. 4, Terns to Woodpeckers. New York: Oxford University Press. 
Cramp, S. (ed.). 1988. Handbook of Birds of Europe, the Middle East, and North Africa: the Birds of the Western Palearctic, Vol. 8, Crows to Finches. New York: Oxford University Press.

Dietler, M. 2001. Theorizing the feast: rituals of consumption, commensal politics, and power in African contexts. In: M. Dietler \& B. Hayden (ed.) Feasts: Archaeological and Ethnographic Perspectives on Food, Politics, and Power: 65-114. Washington (DC): Smithsonian Institution Press.

Dobney, K., M. Beech, \& D. Jacques. 1999. Hunting the broad spectrum recolution: the characterization of Early Neolithic animal exploitation at Qermez Dere, Northern Mesopotamia, in J.C. Driver (ed.) Zooarchaeology of the Pleistocene/Holocene boundary: 47-57. BAR Insternational Series 800, Oxford (UK): BAR.

Flannery, K.V. 1969. “Origins and ecological effects of early domestication in Iran and the Near East, in P.J. Ucko \& G.W. Dimbleby (eds), The domestication and exploitation of plants and animals: 73-100. London: Duckworth.

Gourichon L., 2002. Bird Remains from Jerf el Ahmar, a PPNA Site in Northern Syria, with Special Reference to the Griffon Vulture (Gyps fulvus), in H. Buitenhuis, A. M. Choyke, M. Mashkour, \& A. H. Al-Shiyab (eds), Archaeozoology of the Near East V: 138-52, Proceedings of the fifth international symposium on the archaeozoology of southwestern Asia and adjacent areas (ASWA, Amman, 2000), Gröningen,: ARCPublicatie 62 .

Gourichon L. \& D. Helmer. 2004. Exploitation de petit gibier dans le Moyen Euphrate syrien du XII ${ }^{\mathrm{e}}$ au IX ${ }^{\mathrm{e}}$ millénaires av. J.-C. , in Petits animaux et sociétéshumaines. Du complement alimentaire aux ressources utilitaires: 415-433. XXIV rencontres internationals d'archéologie et d'histoire d'Antibes. Antibes, Éditions APDCA. 
Hauptmann, H. \& K. Schmidt. 2001. - Frühe Tempel - frühe Götter?, in Deutsches Archäologisches Institut (ed.), Archäologische Entdeckungen. Die Forschungen des Deutschen Archäologischen Instituts im 20. Jahrhundert: 258-66. Mainz: Zaberns Bildbände zur Archäologie.

Hayden, B. 1995. A new overview of domestication, in T.D. Price \& A.-B. Gebauer (eds.). Last hunters, first farmers: new perspectives on the transition to agriculture: 273-300. Santa Fe: School of American Research Press.

Heredia, B. (ed.). 1996. International Action Plan for the Imperial Eagle (Aquila heliaca).

Jackson HE, Scott S 1995 The faunal record of the southeastern elite: the implications of economy, social relations, and ideology. Southeastern Archaeology 14(2):103-19.

Johnsgard, P.A. 1988. The Quails, Partridges, and Francolins of the World. New York: Oxford University Press

Johnsgard, P.A. 1991. Bustards, Hemipodes, and Sandgrouse: Birds of Dry Places. New York: Oxford University Press

Kelly, L.S. 2010. A bird's eye view of ritual at the Cahokia site, in deFrance, S.D. \& J.S. Lev-Tov, (eds.), Animals and Complexity: How Zooarchaeologists Contribute to the Study of Complex Society in the New and Old Worlds: 1-11. Oxford (UK): Oxbow Books.

Kent, S., 1989. Cross-cultural perceptions of farmers as hunters and the value of meat, in Kent, S. (ed.), Farmers as hunters: the implications of sedentism: 1-17. Cambridge (UK): Cambridge University Press. 
Kirwan, G.M., K. Boyla, P. Castell, B. Demirci, M, Özen, H. Welch \& T. Marlow. 2008. The birds of Turkey: distribution, taxonomy and breeding of Turkish birds. London: Christopher Helm.

Kozlowski, S.K. 1989. Nemrick 9, a PPN Neolithic site in northern Iraq. Paléorient $15(1): 25-31$.

Kristensen T. J. \& D. H. Holly. 2013. Birds, burials, and sacred cosmology of the indigenous Beothuk of Newfoundland Canada. Cambridge Archaeological Journal 23: 4153.

Kuijt, I., 2000. Keeping the peace: ritual, skull caching, and community integration in the Levantine Neolithic, in Kuijt, I. (ed.), Life in Neolithic farming communities: social organization, identity, and differentiation: 137-62. New York (NY): Kluwer Academic/Plenum Press.

Kuijt, I. \& Goring-Morris, A.N. 2002. Foraging, farming, and social complexity in the PrePottery Neolithic of the southern Levant: a review and synthesis. Journal of World Prehistory 16: 361-440.

Martin, L. Y. Edwards, \& A. Garrad. 2013. Broad spectrum or specialized activity? Birds and tortoises at the Epipaleolothic site of Wadi Jilat 22 in the eastern Jordan steppe. Antiquity 87(337): 649-65.

Munro, N.D. 2004. Zooarchaeological measures of hunting pressure and occupation Intensity in the Natufian. Implications for agricultural origins. Current Anthropology 45, S5-S33.

Munro, N.D. \& L. Grosman. 2010. Early evidence (c. 12000 B.P.) for feasting at a burial cave in Israel. Proceedings of the National Academy of Sciences 107: 15362-66. 
Nesbitt, R. M. 1995. Plants and people in ancient Anatolia. Biblical Archaeologist 58(2): 68-81.

Peasnall, B.L. 2000. The Round-House Horizon along the Taurus/Zagros Arc: A Synthesis of Recent Excavations of Late Epipaleolithic and Early Aceramic Sites in Southeastern Anatolia and Northern Iraq. PhD Dissertation, University of Pennsylvania.

Peters, J. \& K. Schmidt. 2004. Animals in the symbolic world of Pre-Pottery Neolithic Göbeckli Tepe, south-eastern Turkey: a preliminary assessment. Anthropozoologica 39(1):179-218.

Pichon J., 1985. Les rapaces du Tell Mureybet, Syrie. Fouilles J. Cauvin 1971-1974, Cahiers de l'Euphrate 4: 229-59.

Recchi, A. \& A. Gopher. 2002. Birds and humans in the Holocene: The case of Qumran Cave 24 (Dead Sea, Israel). Acta Zoologica Cracoviensia 45: 139-150.

Redding, R.W. 2005. "Breaking the mold, a consideration of variation in the evolution of animal domestication, in J.-D. Vigne, J. Peters, \& D. Helmer (eds.), The First Steps of Animal Domestication: 41-48. Oxford (UK): Oxbow Books.

RiehI, S., E. Asouti, D. Karakaya, B.M. Starkovich, M. Zeidi, \& N. Conard. 2015. Resilience at the transition to agriculture: the long-term landscape and resource development at the Aceramic Neolithic tell site of Chogha Golan (Iran). BioMed Research International dx.doi.org/10.1155/2015/532481.

Rosenberg, M. \& M. Davis. 1992. Hallan Çemi Tepesi, an Early Aceramic Neolithic site in eastern Anatolia: Some preliminary observations concerning material culture. Anatolica 18: $1-18$ 
Rosenberg, M., \& R. W. Redding. 2000. “Hallan Çemi and early village organization in eastern Anatolia, in Kuijt, I. (ed.), Life in Neolithic farming communities: social organization, identity, and differentiation: 39-62. New York (NY): Kluwer Academic/Plenum Press.

Rosenberg, M., M. Nesbitt, R.W. Redding, \& B.L. Peasnall. 1998. Hallan Çemi. Pig husbandry, and post-Pleistocene adaptations along the Taurus-Zagros arc (Turkey). Paléorient 24(1): 25-41.

Russell, N. \& K.J. McGowan. 2003. Dance of the cranes: crane symbolism at C, atalhöyük and beyond. Antiquity 77: 445-55.

Scalf, F. 2012. The role of birds within the religious landscape of Ancient Egypt, in R. Bailleul-LeSuer (ed.), Between Heaven and Earth: Birds in Ancient Egypt: 33-40. Oriental Institute Museum Publications 35, Chicago (IL): The Oriental Institute of the University of Chicago.

Schmidt, K. 2012. Göbekli Tepe. A Stone Age Sanctuary in Southeastern Anatolia, Berlin: ex oriente.

Simmons, T. \& D. Nadel. 1998. The avifauna of the Early Epipalaeolithic site of Ohalo II (19 400 years BP), Israel: species diversity, habitat and seasonality. International Journal of Osteoarchaeology 8: 79-86

Solecki, R. L. \& T. H. McGovern. 1980. Predatory birds and prehistoric man, in S. Diamond (ed.), Theory and Practice. Essays presented to Gene Weltfis: 79-95. Berlin: Mouton. 
Starkovich, B.M. Stiner, M.C. 2009. Hallan Çemi Tepesi: high ranked game exploitation alongside intensive seed processing at the Epipaleolithic Neolithic transition in southeastern Turkey. Anthropozoologica 44: 41-61.

Stiner, M.C. 2001. Thirty years on the "Broad Spectrum Revolution" and Palaeolithic demography, Proceeding of the National Academy of Sciences, USA 13: 6993-96.

Stiner, Mary C, N.D. Munro, Todd A. Surovell. 2000. The tortoise and the hare: smallgame use, the broad-spectrum revolution, and Paleolithic demography, Current Anthropology 41, 39-73

Stordeur D. 2000. - Jerf el Ahmar et l'émergence du Néolithique au Proche Orient, in J. Guilaine (ed.), Premiers paysans du monde. Naissances des agricultures: 33-60. Paris: Éditions Errance.

Stutz, A.J, N.D. Munro, \& G. Bar-Oz. 2009. On increasing the resolution of the Broad Spectrum Revolution in the Southern Levantine Epipaleolithic (19-12 ka). Journal of Human Evolution 56: 294-306.

Tchernov, E. 1993. Exploitation of birds during the Natufian and early Neolithic of the Southern Levant. Archaeofauna: International Journal of archaeozoology 2:121-143.

Tchernov, E. 1994. An Early Neolithic village in the Jordan Valley, part II: the fauna of Netiv Hagdud (American School of Prehistoric Research Bulletin 44). Cambridge (MA): Harvard University, Peabody Museum of Archaeology and Ethnology.

Twiss, K. C. 2008. Transformations in an early agricultural society: feasting in the southern Levantine Pre-Pottery Neolithic. Journal of Anthropological Archaeology 27:418-42. 
Watkins, T., 2010. New light on Neolithic revolution in south-west Asia. Antiquity 84: 621-34.

Voous, K. H. 1989. Owls of the Northern Hemisphere. Cambridge,(MA): MIT Press.

Zeder, M.A., 2011. The origins of agriculture in the Near East. Current Anthropology 54 (S4): S221-S235

Zeder, M.A., 2012a. The broad spectrum revolution at 40: resource diversity, intensification, and an alternative to optimal foraging explanations. Journal of Anthropological Archaeology 31: 241-64.

Zeder, M.A. 2012b. Religion and the revolution: the legacy of Jacques Cauvin. Paléorient 37(1):39-60.

Zeder, M.A. 2015. Comment on Sterelny and Watkins. Cambridge Journal of Archaeology 25:698-700.

Zeder. M. A. 2016. Domestication as a model system for Niche Construction Theory. Evolutionary Ecology 30:325-348. 


\section{Figure Headings}

Figure 1: Map showing location of Hallan Çemi

Figure 2: Hallan Çemi building levels. a. Building Level 3, b. Buidling Level 2, c. Building Level 1.

Figure 3: Hallan Çemi avifauna organized by type, in number of identified specimens (NISP).

Figure 4: Environments around Hallan Çemi (Photo credit: M. Rosenberg)

Figure 5: Seasonality of Hallan Çemi avifauna. a. Habitats represented within seasons, b. Seasonal visitors by building level.

Figure 6: Changes in proportions of game animals by building level. a. Quick (bird and hare) and slow (tortoise) game), b. Large and small game.

Figure 7: Changes in avifauna taxa by building level. a. Gamebirds and waterfowl, $b$. Grey Partridge and Great Bustard, c. Grey Partridge and Chukar, d. Eagle-Owl and eagle.

Figure 8: Residential and CAA avifauna. a. Game Birds, b. Waterfowl, c. Large Waders, d. Raptors.

Figure 9: Body part distributions by type of bird.

Figure 10: Body part distributions for specific taxa and locations. A. Great Bustard in Residential vs. CAA, b. Large Waterfowl in House B vs. Other BL 1 houses, c. Eagle and Eagle-Owls. 
Figure 11: Pedal Phalanges of Hallan Çemi Eagles (right) and Eagle-Owls (left). 
Table 1: Proportions of identifiable bones by taxa. Unshaded rows are percentages within larger taxanomic groups. Shaded rows are percentages of larger taxonomic groups within the assemblage as a whole.

\begin{tabular}{|c|c|c|c|c|c|c|c|c|c|c|c|}
\hline & $\begin{array}{l}\text { Whole } \\
\text { Site }\end{array}$ & $\begin{array}{c}\text { Residential- All } \\
\text { Levels }\end{array}$ & $\begin{array}{c}\text { Residential } \\
\text { BL } 1\end{array}$ & $\begin{array}{c}\text { Residential } \\
\text { BL } 2\end{array}$ & $\begin{array}{c}\text { Residential } \\
\text { BL } 3\end{array}$ & $\begin{array}{l}\text { Residential } \\
\text { BL } 4\end{array}$ & $\begin{array}{l}\text { CAA - All } \\
\text { Levels }\end{array}$ & $\begin{array}{c}\text { CAA BL } \\
1\end{array}$ & $\begin{array}{c}\text { CAA BL } \\
2 \\
\end{array}$ & $\begin{array}{c}\text { CAA BL } \\
3\end{array}$ & $\begin{array}{c}\mathrm{CAA}> \\
\mathrm{BL} 3\end{array}$ \\
\hline $\mathrm{O} / \mathrm{C}$ & $48.9 \%$ & $46.3 \%$ & $47.0 \%$ & $42.8 \%$ & $46.5 \%$ & $37.2 \%$ & $52.1 \%$ & $52.5 \%$ & $35.3 \%$ & $52.5 \%$ & $46.9 \%$ \\
\hline Bos & $0.8 \%$ & $0.5 \%$ & $1.4 \%$ & $0.1 \%$ & $0.0 \%$ & $0.0 \%$ & $1.2 \%$ & $1.2 \%$ & $0.1 \%$ & $0.0 \%$ & $0.5 \%$ \\
\hline Cervid & $25.0 \%$ & $30.6 \%$ & $26.8 \%$ & $38.5 \%$ & $31.3 \%$ & $37.5 \%$ & $18.4 \%$ & $15.2 \%$ & $48.6 \%$ & $31.4 \%$ & $32.2 \%$ \\
\hline Sus & $25.4 \%$ & $22.6 \%$ & $24.8 \%$ & $18.6 \%$ & $22.2 \%$ & $25.3 \%$ & $28.3 \%$ & $31.0 \%$ & $15.9 \%$ & $16.1 \%$ & $20.4 \%$ \\
\hline $\begin{array}{c}\text { Total } \\
\text { Artiodactyl }\end{array}$ & $66.5 \%$ & $57.8 \%$ & $57.9 \%$ & $55.6 \%$ & $52.2 \%$ & $60.6 \%$ & $82.8 \%$ & $82.4 \%$ & $83.7 \%$ & $66.1 \%$ & $75.8 \%$ \\
\hline Ursus & $21.9 \%$ & $20.0 \%$ & $19.0 \%$ & $10.9 \%$ & $16.1 \%$ & $23.5 \%$ & $28.6 \%$ & $25.6 \%$ & $21.2 \%$ & $18.1 \%$ & $45.2 \%$ \\
\hline Vulpes & $56.5 \%$ & $55.1 \%$ & $59.5 \%$ & $80.7 \%$ & $58.6 \%$ & $70.6 \%$ & $54.1 \%$ & $59.3 \%$ & $69.7 \%$ & $59.0 \%$ & $36.6 \%$ \\
\hline $\begin{array}{c}\text { Other } \\
\text { Carnivore* }\end{array}$ & $21.6 \%$ & $24.9 \%$ & $21.5 \%$ & $8.4 \%$ & $25.2 \%$ & $5.9 \%$ & $17.3 \%$ & $15.2 \%$ & $9.1 \%$ & $22.9 \%$ & $18.3 \%$ \\
\hline $\begin{array}{c}\text { Total } \\
\text { Carnivore }\end{array}$ & $6.2 \%$ & $6.0 \%$ & $7.3 \%$ & $8.6 \%$ & $5.4 \%$ & $3.8 \%$ & $5.8 \%$ & $6.3 \%$ & $3.7 \%$ & $12.6 \%$ & $6.4 \%$ \\
\hline Lepus & $82.9 \%$ & $82.8 \%$ & $86.3 \%$ & $93.1 \%$ & $79.4 \%$ & $100.0 \%$ & $82.4 \%$ & $85.7 \%$ & $100.0 \%$ & $62.5 \%$ & $77.8 \%$ \\
\hline Rodent & $17.1 \%$ & $17.2 \%$ & $13.7 \%$ & $6.9 \%$ & $20.6 \%$ & $0.0 \%$ & $17.6 \%$ & $14.3 \%$ & $0.0 \%$ & $37.5 \%$ & $22.2 \%$ \\
\hline $\begin{array}{c}\text { Lepus \& } \\
\text { Rodent }\end{array}$ & $1.7 \%$ & $2.2 \%$ & $3.0 \%$ & $2.1 \%$ & $1.6 \%$ & $1.8 \%$ & $0.8 \%$ & $1.1 \%$ & $0.4 \%$ & $1.2 \%$ & $0.3 \%$ \\
\hline Bird & $4.5 \%$ & $5.9 \%$ & $7.7 \%$ & $7.2 \%$ & $4.7 \%$ & $8.3 \%$ & $1.7 \%$ & $1.6 \%$ & $0.2 \%$ & $5.2 \%$ & $2.2 \%$ \\
\hline Tortoise & $18.7 \%$ & $25.3 \%$ & $20.7 \%$ & $24.9 \%$ & $33.5 \%$ & $24.1 \%$ & $7.5 \%$ & $6.0 \%$ & $11.9 \%$ & $14.8 \%$ & $15.2 \%$ \\
\hline Other** & $2.4 \%$ & $2.8 \%$ & $3.4 \%$ & $1.6 \%$ & $2.7 \%$ & $1.4 \%$ & $1.4 \%$ & $2.6 \%$ & $0.1 \%$ & $0.2 \%$ & $0.2 \%$ \\
\hline Total in NISP & 53,341 & 32,713 & 10,703 & 1380 & 6555 & 444 & 19,422 & 9416 & 900 & 660 & 2912 \\
\hline
\end{tabular}

* mustelids, large and medium felids, canids

** lizards, fish, crustaeceans, molluscs 
Table 2a: Proportions of identifiable avifauna by taxa in NISP. Unshaded rows are percentages within larger taxanomic groups. Shaded rows are percentages of larger taxonomic groups within the assemblage as a whole.

\begin{tabular}{|c|c|c|c|c|c|c|c|c|c|c|c|c|}
\hline Taxa & $\begin{array}{l}\text { Whole } \\
\text { Site }\end{array}$ & $\begin{array}{l}\text { Residential } \\
\text { - All Levels }\end{array}$ & $\begin{array}{l}\text { Residential } \\
\text { BL } 1\end{array}$ & $\begin{array}{c}\text { Residential } \\
\text { BL } 2\end{array}$ & $\begin{array}{c}\text { Residential } \\
\text { BL } 3\end{array}$ & $\begin{array}{c}\text { Residential } \\
\text { BL } 4\end{array}$ & $\begin{array}{c}\text { CAA - } \\
\text { All } \\
\text { Levels }\end{array}$ & $\begin{array}{c}\text { CAA BL } \\
1\end{array}$ & $\begin{array}{c}\text { CAA BL } \\
3\end{array}$ & $\begin{array}{c}\mathrm{CAA}> \\
\mathrm{BL} 3\end{array}$ & $\begin{array}{c}\text { House } \\
1 B\end{array}$ & $\begin{array}{c}\text { Other } \\
\text { BL } 1 \\
\text { Houses }\end{array}$ \\
\hline Alectoris cf. chukar & $12.7 \%$ & $15.2 \%$ & $8.9 \%$ & $11.1 \%$ & $24.1 \%$ & $40.0 \%$ & $1.4 \%$ & $1.9 \%$ & $0.0 \%$ & $0.0 \%$ & $8.3 \%$ & $8.5 \%$ \\
\hline Otis tarda & $35.2 \%$ & $30.7 \%$ & $31.9 \%$ & $33.3 \%$ & $44.8 \%$ & $20.0 \%$ & $70.4 \%$ & $64.8 \%$ & $80.0 \%$ & $90.9 \%$ & $21.7 \%$ & $28.8 \%$ \\
\hline Perdix perdix & $48.7 \%$ & $50.5 \%$ & $51.8 \%$ & $55.6 \%$ & $31.0 \%$ & $40.0 \%$ & $25.4 \%$ & $29.6 \%$ & $20.0 \%$ & $9.1 \%$ & $65.0 \%$ & $49.2 \%$ \\
\hline Other* & $3.3 \%$ & $3.6 \%$ & $7.3 \%$ & $0.0 \%$ & $0.0 \%$ & $0.0 \%$ & $2.8 \%$ & $3.7 \%$ & $0.0 \%$ & $0.0 \%$ & $5.0 \%$ & $13.6 \%$ \\
\hline Total Gamebird & $47.0 \%$ & $49.3 \%$ & $56.7 \%$ & $48.6 \%$ & $39.2 \%$ & $62.5 \%$ & $35.9 \%$ & $38.6 \%$ & $31.3 \%$ & $29.7 \%$ & $47.2 \%$ & $54.6 \%$ \\
\hline Crow \& Raven & $4.0 \%$ & $3.4 \%$ & $4.7 \%$ & $0.0 \%$ & $2.7 \%$ & $0.0 \%$ & $5.1 \%$ & $3.6 \%$ & $25.0 \%$ & $0.0 \%$ & $4.7 \%$ & $1.9 \%$ \\
\hline Aquila sp. & $23.2 \%$ & $14.4 \%$ & $11.9 \%$ & $20.0 \%$ & $20.0 \%$ & $50.0 \%$ & $36.9 \%$ & $19.0 \%$ & $66.7 \%$ & $66.7 \%$ & $15.4 \%$ & $12.5 \%$ \\
\hline Bubo bubo & $38.9 \%$ & $43.9 \%$ & $52.4 \%$ & $40.0 \%$ & $32.0 \%$ & $0.0 \%$ & $32.3 \%$ & $40.5 \%$ & $33.3 \%$ & $33.3 \%$ & $53.8 \%$ & $62.5 \%$ \\
\hline $\begin{array}{c}\text { Other Large } \\
\text { Raptors * }\end{array}$ & $7.9 \%$ & $4.5 \%$ & $2.4 \%$ & $0.0 \%$ & $8.0 \%$ & $0.0 \%$ & $15.4 \%$ & $19.0 \%$ & $0.0 \%$ & $0.0 \%$ & $0.0 \%$ & $0.0 \%$ \\
\hline $\begin{array}{c}\text { Other Small } \\
\text { Raptors* }\end{array}$ & $30.0 \%$ & $37.1 \%$ & $33.3 \%$ & $40.0 \%$ & $40.0 \%$ & $50.0 \%$ & $15.4 \%$ & $21.4 \%$ & $0.0 \%$ & $0.0 \%$ & $30.8 \%$ & $25.0 \%$ \\
\hline Total Raptors & $17.6 \%$ & $14.8 \%$ & $12.5 \%$ & $13.5 \%$ & $16.9 \%$ & $25.0 \%$ & $32.8 \%$ & $30.0 \%$ & $18.8 \%$ & $54.1 \%$ & $10.2 \%$ & $7.4 \%$ \\
\hline Large Waterfowl* & $74.3 \%$ & $72.6 \%$ & $76.0 \%$ & $81.8 \%$ & $71.7 \%$ & $100.0 \%$ & $92.3 \%$ & $97.1 \%$ & $66.7 \%$ & $50.0 \%$ & $81.8 \%$ & $69.0 \%$ \\
\hline Small Waterfowl* & $25.7 \%$ & $27.4 \%$ & $24.0 \%$ & $18.2 \%$ & $28.3 \%$ & $0.0 \%$ & $7.7 \%$ & $2.9 \%$ & $33.3 \%$ & $50.0 \%$ & $18.2 \%$ & $31.0 \%$ \\
\hline Total Waterfowl & $23.9 \%$ & $24.6 \%$ & $28.5 \%$ & $29.7 \%$ & $35.8 \%$ & $12.5 \%$ & $19.7 \%$ & $24.3 \%$ & $18.8 \%$ & $5.4 \%$ & $34.6 \%$ & $26.9 \%$ \\
\hline Grus cf. grus & $69.1 \%$ & $65.5 \%$ & $73.1 \%$ & $100.0 \%$ & $71.4 \%$ & $0.0 \%$ & $83.3 \%$ & $75.0 \%$ & $100.0 \%$ & $75.0 \%$ & $66.7 \%$ & $75.0 \%$ \\
\hline $\begin{array}{c}\text { Other Large } \\
\text { Waders* }\end{array}$ & $30.9 \%$ & $34.5 \%$ & $26.9 \%$ & $0.0 \%$ & $28.6 \%$ & $0.0 \%$ & $16.7 \%$ & $25.0 \%$ & $0.0 \%$ & $25.0 \%$ & $33.3 \%$ & $25.0 \%$ \\
\hline $\begin{array}{c}\text { Total Large } \\
\text { Waders }\end{array}$ & $5.9 \%$ & $6.1 \%$ & $7.7 \%$ & $5.4 \%$ & $4.7 \%$ & $0.0 \%$ & $6.1 \%$ & $2.9 \%$ & $6.3 \%$ & $10.8 \%$ & $2.4 \%$ & $7.4 \%$ \\
\hline Small Waders & $0.4 \%$ & $0.6 \%$ & $0.3 \%$ & $2.7 \%$ & $0.0 \%$ & $0.0 \%$ & $0.0 \%$ & $0.0 \%$ & $0.0 \%$ & $0.0 \%$ & $0.8 \%$ & $0.0 \%$ \\
\hline Water Birds & $1.1 \%$ & $1.2 \%$ & $1.5 \%$ & $0.0 \%$ & $0.7 \%$ & $0.0 \%$ & $0.5 \%$ & $0.7 \%$ & $0.0 \%$ & $0.0 \%$ & $0.0 \%$ & $1.9 \%$ \\
\hline Total NISP & 1154 & 892 & 337 & 37 & 148 & 8 & 198 & 140 & 16 & 37 & 127 & 108 \\
\hline
\end{tabular}

* see Table S3 
Table 2b: Proportions of identifiable avifauna by weight in grams. Unshaded rows are percentages within larger taxanomic groups. Shaded rows are percentages of larger taxonomic groups within the assemblage as a whole.

\begin{tabular}{|c|c|c|c|c|c|c|c|c|c|c|c|c|}
\hline Taxa & $\begin{array}{l}\text { Whole } \\
\text { Site }\end{array}$ & $\begin{array}{l}\text { Residential } \\
\text { - All Levels }\end{array}$ & $\begin{array}{c}\text { Residential } \\
\text { BL } 1\end{array}$ & $\begin{array}{c}\text { Residential } \\
\text { BL } 2\end{array}$ & $\begin{array}{c}\text { Residential } \\
\text { BL } 3\end{array}$ & $\begin{array}{l}\text { Residential } \\
\text { BL } 4\end{array}$ & $\begin{array}{c}\text { CAA - } \\
\text { All } \\
\text { Levels }\end{array}$ & $\begin{array}{c}\text { CAA BL } \\
1\end{array}$ & $\begin{array}{c}\text { CAA BL } \\
3\end{array}$ & $\begin{array}{c}\mathrm{CAA}> \\
\mathrm{BL} 3\end{array}$ & $\begin{array}{c}\text { House } \\
1 \mathrm{~B}\end{array}$ & $\begin{array}{c}\text { Other } \\
\text { BL } 1 \\
\text { Houses }\end{array}$ \\
\hline Alectoris cf. chukar & $4.1 \%$ & $5.6 \%$ & $2.8 \%$ & $6.5 \%$ & $6.9 \%$ & $16.7 \%$ & $0.3 \%$ & $0.4 \%$ & $0.0 \%$ & $0.5 \%$ & $3.1 \%$ & $0.0 \%$ \\
\hline Otis tarda & $81.0 \%$ & $76.7 \%$ & $78.4 \%$ & $66.3 \%$ & $85.8 \%$ & $66.7 \%$ & $95.9 \%$ & $95.8 \%$ & $94.6 \%$ & $4.8 \%$ & $63.8 \%$ & $96.9 \%$ \\
\hline Perdix perdix & $13.9 \%$ & $16.5 \%$ & $16.4 \%$ & $27.2 \%$ & $7.4 \%$ & $16.7 \%$ & $3.5 \%$ & $3.6 \%$ & $5.4 \%$ & $0.5 \%$ & $31.5 \%$ & $3.1 \%$ \\
\hline Other* & $0.9 \%$ & $1.2 \%$ & $2.4 \%$ & $0.0 \%$ & $0.0 \%$ & $0.0 \%$ & $0.2 \%$ & $0.3 \%$ & $0.0 \%$ & $1.6 \%$ & $1.7 \%$ & $0.0 \%$ \\
\hline Total Gamebird & $41.9 \%$ & $42.8 \%$ & $44.1 \%$ & $35.1 \%$ & $43.3 \%$ & $52.2 \%$ & $41.6 \%$ & $44.3 \%$ & $25.3 \%$ & $1.5 \%$ & $32.3 \%$ & $27.1 \%$ \\
\hline Crow \& Raven & $1.5 \%$ & $1.5 \%$ & $2.1 \%$ & $0.0 \%$ & $0.8 \%$ & $0.0 \%$ & $1.2 \%$ & $1.1 \%$ & $4.1 \%$ & $0.0 \%$ & $1.6 \%$ & $0.0 \%$ \\
\hline Aquila sp. & $26.8 \%$ & $16.3 \%$ & $10.2 \%$ & $14.6 \%$ & $29.7 \%$ & $83.3 \%$ & $38.5 \%$ & $23.2 \%$ & $91.1 \%$ & $1.4 \%$ & $20.0 \%$ & $74.8 \%$ \\
\hline Bubo bubo & $49.6 \%$ & $60.8 \%$ & $62.3 \%$ & $61.0 \%$ & $45.7 \%$ & $0.0 \%$ & $35.9 \%$ & $44.0 \%$ & $8.9 \%$ & $0.5 \%$ & $66.5 \%$ & $16.5 \%$ \\
\hline $\begin{array}{c}\text { Other Large } \\
\text { Raptors * }\end{array}$ & $13.1 \%$ & $10.4 \%$ & $18.6 \%$ & $0.0 \%$ & $8.0 \%$ & $0.0 \%$ & $17.9 \%$ & $22.3 \%$ & $0.0 \%$ & $3.8 \%$ & $0.0 \%$ & $8.3 \%$ \\
\hline $\begin{array}{c}\text { Other Small } \\
\text { Raptors* }\end{array}$ & $10.5 \%$ & $12.5 \%$ & $9.0 \%$ & $24.4 \%$ & $16.6 \%$ & $16.7 \%$ & $7.7 \%$ & $10.5 \%$ & $0.0 \%$ & $0.8 \%$ & $13.5 \%$ & $0.5 \%$ \\
\hline Total Raptors & $21.6 \%$ & $18.1 \%$ & $16.0 \%$ & $15.6 \%$ & $12.1 \%$ & $26.1 \%$ & $31.7 \%$ & $28.0 \%$ & $38.4 \%$ & $1.0 \%$ & $15.3 \%$ & $60.4 \%$ \\
\hline Large Waterfowl* & $85.8 \%$ & $84.1 \%$ & $89.0 \%$ & $0.0 \%$ & $82.5 \%$ & $100.0 \%$ & $92.3 \%$ & $99.0 \%$ & $90.0 \%$ & $111.1 \%$ & $92.3 \%$ & $33.3 \%$ \\
\hline Small Waterfowl* & $14.2 \%$ & $15.9 \%$ & $11.0 \%$ & $100.0 \%$ & $17.5 \%$ & $0.0 \%$ & $7.7 \%$ & $1.0 \%$ & $10.0 \%$ & $55.6 \%$ & $7.7 \%$ & $66.7 \%$ \\
\hline Total Waterfowl & $26.5 \%$ & $27.9 \%$ & $27.1 \%$ & $33.2 \%$ & $38.7 \%$ & $21.7 \%$ & $20.4 \%$ & $24.5 \%$ & $6.8 \%$ & $0.1 \%$ & $41.0 \%$ & $1.7 \%$ \\
\hline Grus cf. grus & $83.3 \%$ & $81.2 \%$ & $87.8 \%$ & $100.0 \%$ & $91.7 \%$ & $0.0 \%$ & $89.0 \%$ & $76.5 \%$ & $100.0 \%$ & $0.2 \%$ & $94.9 \%$ & $87.2 \%$ \\
\hline $\begin{array}{c}\text { Other Large } \\
\text { Waders* }\end{array}$ & $16.7 \%$ & $18.8 \%$ & $12.2 \%$ & $0.0 \%$ & $8.3 \%$ & $0.0 \%$ & $11.0 \%$ & $23.5 \%$ & $0.0 \%$ & $0.0 \%$ & $5.1 \%$ & $12.8 \%$ \\
\hline $\begin{array}{c}\text { Total Large } \\
\text { Waders }\end{array}$ & $7.5 \%$ & $8.5 \%$ & $9.5 \%$ & $15.3 \%$ & $5.0 \%$ & $0.0 \%$ & $5.0 \%$ & $2.0 \%$ & $25.3 \%$ & $351.8 \%$ & $7.0 \%$ & $10.8 \%$ \\
\hline Small Waders & $0.1 \%$ & $0.2 \%$ & $0.1 \%$ & $0.8 \%$ & $0.0 \%$ & $0.0 \%$ & $0.0 \%$ & $0.0 \%$ & $0.0 \%$ & $0.0 \%$ & $0.0 \%$ & $0.0 \%$ \\
\hline Water Birds & $0.9 \%$ & $0.9 \%$ & $1.1 \%$ & $0.0 \%$ & $0.1 \%$ & $0.0 \%$ & $0.1 \%$ & $0.1 \%$ & $0.0 \%$ & $0.0 \%$ & $2.7 \%$ & $0.0 \%$ \\
\hline Total Weight & 1146.7 & 792.8 & 362.5 & 26.2 & 144.4 & 2.3 & 308.2 & 251.8 & 14.6 & 36.1 & 111.0 & 36.1 \\
\hline
\end{tabular}

* see Table S3 
Table 3: Taxa by habitat

\begin{tabular}{|c|c|c|}
\hline Habitat & Type & Taxa \\
\hline \multirow{9}{*}{ Grassland } & \multirow{5}{*}{ Gamebirds } & Coturnix coturnix \\
\hline & & Otis tarda \\
\hline & & Perdix perdix \\
\hline & & Pterocles orientalis \\
\hline & & Tetrax tetrax \\
\hline & \multirow{2}{*}{ Raptors } & Asio flammeus \\
\hline & & Buteo rufinus \\
\hline & Small Wader & Burhinus oedicnemus \\
\hline & Crows & Corvus frugilegus \\
\hline \multirow{3}{*}{ Mountains } & \multirow{3}{*}{ Raptors } & Aegypius monachus \\
\hline & & Gyps fulvus \\
\hline & & Falco peregrinus \\
\hline \multirow{2}{*}{ Rocky } & Gamebirds & Alectoris chukar \\
\hline & Raptors & Bubo bubo \\
\hline \multirow{3}{*}{$\begin{array}{l}\text { Wooded } \\
\text { Steppe }\end{array}$} & Raptors & Falco cherrug \\
\hline & \multirow{2}{*}{ Crows } & Corvus monedula \\
\hline & & Pica pica \\
\hline \multirow{6}{*}{ Woodland } & Gamebirds & Columba palumbus \\
\hline & \multirow{5}{*}{ Raptors } & Accipiter nisus \\
\hline & & Aquila sp. \\
\hline & & Asio otus \\
\hline & & Milvus milvus \\
\hline & & Milvus migrans \\
\hline \multirow{2}{*}{ Wetlands } & \multirow{2}{*}{ Waterfowl } & Anas acuta \\
\hline & & Anas penelope \\
\hline
\end{tabular}




\begin{tabular}{|c|c|}
\hline & Anas querquedula \\
\hline & Anas crecca \\
\hline & Anas platyrhynchos \\
\hline & Anas sp. \\
\hline & Anser albifrons \\
\hline & Anser anser/fabalis \\
\hline & Aythya ferina \\
\hline & Aythya sp. \\
\hline & Cygnus sp. \\
\hline & Mergellus albellus \\
\hline & Mergus merganser \\
\hline & Tadorna ferruginea \\
\hline & Tadorna sp. \\
\hline \multirow{6}{*}{ Large Waders } & Ardea purpurea \\
\hline & Ardea cinerea \\
\hline & Ardea sp. \\
\hline & Botaurus stellaris \\
\hline & Ciconia ciconia \\
\hline & Grus grus \\
\hline \multirow{3}{*}{ Small Waders } & Himantopus himantopus \\
\hline & Numenius arquata \\
\hline & Vanellus vanellus \\
\hline \multirow{6}{*}{ Waterbirds } & Crex crex \\
\hline & Fulica atra \\
\hline & Gallinula chloropus \\
\hline & Larus ridibundus \\
\hline & Phalacrocorax carbo \\
\hline & Podiceps nigricollis \\
\hline
\end{tabular}


Table 4: Habitats by types of avifauna. Unshaded rows are percentages within larger taxanomic groups. Shaded rows are percentages of larger taxonomic groups within the assemblage as a whole.

\begin{tabular}{|c|c|c|c|c|c|c|c|c|c|c|}
\hline Habitat & Whole Site & $\begin{array}{l}\text { Residential } \\
\text { - All Levels }\end{array}$ & $\begin{array}{l}\text { Residential } \\
\text { BL } 1\end{array}$ & $\begin{array}{l}\text { Residential } \\
\text { BL } 2\end{array}$ & $\begin{array}{c}\text { Residential } \\
\text { BL } 3\end{array}$ & $\begin{array}{c}\text { Residential } \\
\text { BL } 4\end{array}$ & $\begin{array}{l}\text { CAA - All } \\
\text { Levels }\end{array}$ & CAA BL 1 & CAA BL 3 & $\begin{array}{c}\mathrm{CAA}>\mathrm{BL} \\
3\end{array}$ \\
\hline Gamebirds & $97.1 \%$ & $97.6 \%$ & $97.7 \%$ & $100.0 \%$ & $91.7 \%$ & $100.0 \%$ & $95.8 \%$ & $94.5 \%$ & $100.0 \%$ & $100.0 \%$ \\
\hline Crow & $1.7 \%$ & $1.3 \%$ & $1.7 \%$ & $0.0 \%$ & $6.3 \%$ & $0.0 \%$ & $1.4 \%$ & $1.8 \%$ & $0.0 \%$ & $0.0 \%$ \\
\hline Raptor & $1.0 \%$ & $0.8 \%$ & $0.6 \%$ & $0.0 \%$ & $2.1 \%$ & $0.0 \%$ & $2.8 \%$ & $3.6 \%$ & $0.0 \%$ & $0.0 \%$ \\
\hline Small Wader & $0.2 \%$ & $0.3 \%$ & $0.0 \%$ & $0.0 \%$ & $0.0 \%$ & $0.0 \%$ & $0.0 \%$ & $0.0 \%$ & $0.0 \%$ & $0.0 \%$ \\
\hline Grassland & $42.1 \%$ & $42.6 \%$ & $47.0 \%$ & $43.2 \%$ & $32.2 \%$ & $62.5 \%$ & $36.7 \%$ & $39.6 \%$ & $27.8 \%$ & $30.6 \%$ \\
\hline Raptor & $100.0 \%$ & $100.0 \%$ & $100.0 \%$ & $0.0 \%$ & $100.0 \%$ & $0.0 \%$ & $100.0 \%$ & $100.0 \%$ & $100.0 \%$ & $100.0 \%$ \\
\hline Mountain & $1.4 \%$ & $0.8 \%$ & $0.3 \%$ & $0.0 \%$ & $2.0 \%$ & $0.0 \%$ & $4.6 \%$ & $5.0 \%$ & $0.0 \%$ & $5.6 \%$ \\
\hline Gamebird & $46.6 \%$ & $53.6 \%$ & $43.6 \%$ & $50.0 \%$ & $35.0 \%$ & $0.0 \%$ & $4.5 \%$ & $5.6 \%$ & $0.0 \%$ & $0.0 \%$ \\
\hline Raptor & $53.4 \%$ & $46.4 \%$ & $56.4 \%$ & $50.0 \%$ & $65.0 \%$ & $0.0 \%$ & $95.5 \%$ & $94.4 \%$ & $100.0 \%$ & $100.0 \%$ \\
\hline Rocky terrain & $13.0 \%$ & $14.2 \%$ & $10.7 \%$ & $10.8 \%$ & $14.8 \%$ & $0.0 \%$ & $11.2 \%$ & $12.9 \%$ & $5.6 \%$ & $8.3 \%$ \\
\hline Crow & $71.4 \%$ & $66.7 \%$ & $50.0 \%$ & $0.0 \%$ & $100.0 \%$ & $0.0 \%$ & $0.0 \%$ & $0.0 \%$ & $0.0 \%$ & $0.0 \%$ \\
\hline Raptor & $28.6 \%$ & $33.3 \%$ & $50.0 \%$ & $0.0 \%$ & $0.0 \%$ & $0.0 \%$ & $0.0 \%$ & $0.0 \%$ & $0.0 \%$ & $0.0 \%$ \\
\hline Wooded steppe & $0.6 \%$ & $0.7 \%$ & $0.5 \%$ & $0.0 \%$ & $0.7 \%$ & $0.0 \%$ & $0.0 \%$ & $0.0 \%$ & $0.0 \%$ & $0.0 \%$ \\
\hline Gamebird & $2.0 \%$ & $1.9 \%$ & $0.0 \%$ & $0.0 \%$ & $0.0 \%$ & $100.0 \%$ & $2.6 \%$ & $5.6 \%$ & $0.0 \%$ & $0.0 \%$ \\
\hline Crow & $30.0 \%$ & $37.0 \%$ & $66.7 \%$ & $0.0 \%$ & $0.0 \%$ & $0.0 \%$ & $23.1 \%$ & $22.2 \%$ & $66.7 \%$ & $0.0 \%$ \\
\hline Raptor & $68.0 \%$ & $61.1 \%$ & $33.3 \%$ & $100.0 \%$ & $100.0 \%$ & $0.0 \%$ & $74.4 \%$ & $72.2 \%$ & $33.3 \%$ & $100.0 \%$ \\
\hline Woodland & $8.8 \%$ & $6.1 \%$ & $5.2 \%$ & $8.1 \%$ & $6.7 \%$ & $12.5 \%$ & $19.9 \%$ & $12.9 \%$ & $33.3 \%$ & $38.9 \%$ \\
\hline Raptor & $6.7 \%$ & $7.7 \%$ & $3.8 \%$ & $0.0 \%$ & $4.7 \%$ & $50.0 \%$ & $3.7 \%$ & $4.9 \%$ & $0.0 \%$ & $0.0 \%$ \\
\hline Waterfowl & $71.5 \%$ & $70.0 \%$ & $70.7 \%$ & $76.8 \%$ & $84.4 \%$ & $50.0 \%$ & $72.2 \%$ & $85.4 \%$ & $50.0 \%$ & $66.7 \%$ \\
\hline Large wader & $17.6 \%$ & $17.6 \%$ & $19.5 \%$ & $14.3 \%$ & $10.9 \%$ & $0.0 \%$ & $22.2 \%$ & $9.8 \%$ & $50.0 \%$ & $33.3 \%$ \\
\hline Small wader & $1.0 \%$ & $1.3 \%$ & $0.8 \%$ & $7.1 \%$ & $0.0 \%$ & $0.0 \%$ & $0.0 \%$ & $0.0 \%$ & $0.0 \%$ & $0.0 \%$ \\
\hline Water bird & $3.4 \%$ & $3.5 \%$ & $3.8 \%$ & $0.0 \%$ & $0.0 \%$ & $0.0 \%$ & $1.9 \%$ & $0.0 \%$ & $0.0 \%$ & $0.0 \%$ \\
\hline Wetland & $34.0 \%$ & $35.6 \%$ & $38.3 \%$ & $37.8 \%$ & $43.0 \%$ & $25.0 \%$ & $27.6 \%$ & $29.5 \%$ & $33.3 \%$ & $16.7 \%$ \\
\hline Total & 1137 & 880 & 366 & 37 & 148 & 8 & 196 & 139 & 18 & 36 \\
\hline
\end{tabular}


Table 5: Taxa by season, habitat, and type

\begin{tabular}{|c|c|c|c|}
\hline Season & Habitat & Type & Taxa \\
\hline \multirow{6}{*}{$\begin{array}{l}\text { Spring/ } \\
\text { Autumn } \\
\text { Visitors }\end{array}$} & Grassland & Raptor & Asio flammeus \\
\hline & \multirow{5}{*}{ Wetland } & Waterfowl & Anas querquedula \\
\hline & & Large wader & Ardea purpurea \\
\hline & & \multirow{2}{*}{ Small Wader } & Himantopus himantopus \\
\hline & & & Numenius arquata \\
\hline & & Water Bird & Crex crex \\
\hline \multirow{15}{*}{$\begin{array}{l}\text { Summer } \\
\text { Vistors }\end{array}$} & \multirow{3}{*}{ Grassland } & \multirow{2}{*}{ Gamebirds } & Coturnix coturnix \\
\hline & & & Pterocles orientalis \\
\hline & & Small Wader & Burhinus oedicnemus \\
\hline & \multirow{2}{*}{ Mountain } & \multirow{2}{*}{ Raptors } & Aegypius monachus \\
\hline & & & Gyps fulvus \\
\hline & \multirow{6}{*}{ Woodland } & Gamebirds & Columba palumbus \\
\hline & & \multirow{5}{*}{ Raptors } & Accipiter nisus \\
\hline & & & Aquila sp. \\
\hline & & & Asio otus \\
\hline & & & Milvus milvus \\
\hline & & & Milvus migrans \\
\hline & \multirow{4}{*}{ Wetland } & Water Fowl & Tadorna ferruginea \\
\hline & & Large Wader & Ciconia ciconia \\
\hline & & \multirow{2}{*}{ Water Bird } & Phalacrocorax carbo \\
\hline & & & Podiceps nigricollis \\
\hline \multirow{4}{*}{$\begin{array}{l}\text { Winter } \\
\text { Visitors }\end{array}$} & Grassland & Crow & Corvus frugilegus \\
\hline & Wooded steppe & Raptor & Falco cherrug \\
\hline & \multirow{2}{*}{ Wetland } & \multirow{2}{*}{ Raptor } & Circus aeruginosus \\
\hline & & & Circus sp. \\
\hline
\end{tabular}




\begin{tabular}{|c|c|c|c|}
\hline & & & Anas acuta \\
\hline & & & Anas penelope \\
\hline & & & Anas acuta/platyrhynchos \\
\hline & & & Anas crecca \\
\hline & & & Anas platyrhynchos \\
\hline & & & Anas sp. \\
\hline & & W/atorfoul & Anser albifrons \\
\hline & & & Anser anser/fabalis \\
\hline & & & Ardea cinerea \\
\hline & & & Aythya ferina \\
\hline & & & Aythya sp. \\
\hline & & & Cygnus sp. \\
\hline & & & Mergellus albellus \\
\hline & & & Mergus merganser \\
\hline & & Large Wader & Botaurus stellaris \\
\hline & & & Grus grus \\
\hline & & Small Wader & Vanellus vanellus \\
\hline & & Water Bird & Larus ridibundus \\
\hline & & & Perdix perdix \\
\hline & Grocsla & - & Tetrax tetrax \\
\hline & 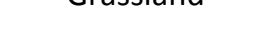 & Rantor & Buteo rufinus \\
\hline & & & Otis tarda \\
\hline Year Round & Mountain & Raptor & Falco peregrinus \\
\hline Residents & Rocky & Gamebird & Alectoris chukar \\
\hline & Wooded stenne & Crow & Corvus monedula \\
\hline & & & Pica pica \\
\hline & Woodland & Crow & Corvus corax \\
\hline & & & Corvus cornix \\
\hline
\end{tabular}




\begin{tabular}{|l|l|l|l|} 
& Wetland & Water Bird & Fulica atra \\
\cline { 3 - 3 } & & Gallinula chloropus \\
\hline
\end{tabular}


Table 6: Seasons by avifauna habitat. Unshaded rows are percentages within larger taxanomic groups. Shaded rows are percentages of larger taxonomic groups within the assemblage as a whole.

\begin{tabular}{|c|c|c|c|c|c|c|c|c|c|c|}
\hline Season & Whole Site & $\begin{array}{l}\text { Residential } \\
\text { - All Levels }\end{array}$ & $\begin{array}{l}\text { Residential } \\
\text { BL } 1\end{array}$ & $\begin{array}{l}\text { Residential } \\
\text { BL } 2\end{array}$ & $\begin{array}{c}\text { Residential } \\
\text { BL } 3\end{array}$ & $\begin{array}{l}\text { Residential } \\
\text { BL } 4\end{array}$ & $\begin{array}{l}\text { CAA - All } \\
\text { Levels }\end{array}$ & CAA BL 1 & CAA BL 3 & $\begin{array}{c}C A A>B L \\
3\end{array}$ \\
\hline Grassland & $30.0 \%$ & $14.3 \%$ & $0.0 \%$ & $0.0 \%$ & $50.0 \%$ & $0.0 \%$ & $100.0 \%$ & $100.0 \%$ & $0.0 \%$ & $0.0 \%$ \\
\hline Wetland & $70.0 \%$ & $85.7 \%$ & $100.0 \%$ & $0.0 \%$ & $50.0 \%$ & $0.0 \%$ & $0.0 \%$ & $0.0 \%$ & $0.0 \%$ & $0.0 \%$ \\
\hline Spring/Autumn & $0.9 \%$ & $0.8 \%$ & $0.5 \%$ & $0.0 \%$ & $1.4 \%$ & $0.0 \%$ & $1.0 \%$ & $1.5 \%$ & $0.0 \%$ & $0.0 \%$ \\
\hline Grassland & $6.6 \%$ & $10.3 \%$ & $23.5 \%$ & $0.0 \%$ & $0.0 \%$ & $0.0 \%$ & $2.5 \%$ & $4.5 \%$ & $0.0 \%$ & $0.0 \%$ \\
\hline Mountain & $14.2 \%$ & $10.3 \%$ & $5.9 \%$ & $0.0 \%$ & $14.3 \%$ & $0.0 \%$ & $22.5 \%$ & $31.8 \%$ & $0.0 \%$ & $12.5 \%$ \\
\hline Woodland & $66.0 \%$ & $58.6 \%$ & $41.2 \%$ & $100.0 \%$ & $71.4 \%$ & $100.0 \%$ & $75.0 \%$ & $63.6 \%$ & $100.0 \%$ & $87.5 \%$ \\
\hline Wetland & $13.2 \%$ & $20.7 \%$ & $29.4 \%$ & $0.0 \%$ & $14.3 \%$ & $0.0 \%$ & $0.0 \%$ & $0.0 \%$ & $0.0 \%$ & $0.0 \%$ \\
\hline Summer & $9.3 \%$ & $6.6 \%$ & $4.7 \%$ & $8.1 \%$ & $9.5 \%$ & $12.5 \%$ & $20.5 \%$ & $16.2 \%$ & $13.3 \%$ & $50.0 \%$ \\
\hline Grassland & $2.2 \%$ & $1.7 \%$ & $2.3 \%$ & $0.0 \%$ & $3.2 \%$ & $0.0 \%$ & $1.9 \%$ & $2.4 \%$ & $0.0 \%$ & $0.0 \%$ \\
\hline Wooded Steppe & $0.5 \%$ & $0.7 \%$ & $0.8 \%$ & $0.0 \%$ & $0.0 \%$ & $0.0 \%$ & $0.0 \%$ & $0.0 \%$ & $0.0 \%$ & $0.0 \%$ \\
\hline Wetland & $97.3 \%$ & $97.6 \%$ & $96.9 \%$ & $100.0 \%$ & $96.8 \%$ & $100.0 \%$ & $98.1 \%$ & $97.6 \%$ & $100.0 \%$ & $100.0 \%$ \\
\hline Winter & $32.2 \%$ & $33.5 \%$ & $35.1 \%$ & $37.8 \%$ & $42.2 \%$ & $25.0 \%$ & $27.2 \%$ & $30.1 \%$ & $40.0 \%$ & $9.4 \%$ \\
\hline Grassland & $70.8 \%$ & $70.2 \%$ & $47.6 \%$ & $80.0 \%$ & $63.8 \%$ & $60.0 \%$ & $68.0 \%$ & $68.9 \%$ & $50.0 \%$ & $68.8 \%$ \\
\hline Mountain & $0.2 \%$ & $0.2 \%$ & $0.0 \%$ & $0.0 \%$ & $1.4 \%$ & $0.0 \%$ & $0.0 \%$ & $0.0 \%$ & $0.0 \%$ & $0.0 \%$ \\
\hline Rocky & $22.7 \%$ & $24.0 \%$ & $11.2 \%$ & $20.0 \%$ & $31.9 \%$ & $40.0 \%$ & $22.0 \%$ & $24.3 \%$ & $10.0 \%$ & $18.8 \%$ \\
\hline Wooded Steppe & $0.8 \%$ & $0.8 \%$ & $0.0 \%$ & $0.0 \%$ & $1.4 \%$ & $0.0 \%$ & $0.0 \%$ & $0.0 \%$ & $0.0 \%$ & $0.0 \%$ \\
\hline Woodland & $4.6 \%$ & $3.9 \%$ & $3.7 \%$ & $0.0 \%$ & $1.4 \%$ & $0.0 \%$ & $9.0 \%$ & $5.4 \%$ & $40.0 \%$ & $0.0 \%$ \\
\hline Wetland & $0.9 \%$ & $1.0 \%$ & $0.3 \%$ & $0.0 \%$ & $0.0 \%$ & $0.0 \%$ & $1.0 \%$ & $1.4 \%$ & $0.0 \%$ & $12.5 \%$ \\
\hline Resident & $57.5 \%$ & $59.1 \%$ & $59.7 \%$ & $54.1 \%$ & $46.9 \%$ & $62.5 \%$ & $51.3 \%$ & $54.4 \%$ & $66.7 \%$ & $50.0 \%$ \\
\hline Total & 1141 & 875 & 365 & 37 & 147 & 8 & 195 & 139 & 18 & 35 \\
\hline
\end{tabular}


Table 7: Proportions of Hallan Çemi fauna by size of game. Unshaded rows are percentages within larger taxanomic groups. Shaded rows are percentages of larger taxonomic groups within the assemblage as a whole.

\begin{tabular}{|c|c|c|c|c|c|c|c|c|c|c|c|}
\hline & $\begin{array}{l}\text { Whole } \\
\text { Site }\end{array}$ & $\begin{array}{c}\text { Residential- } \\
\text { All Levels }\end{array}$ & $\begin{array}{c}\text { Residential } \\
\text { BL } 1\end{array}$ & $\begin{array}{c}\text { Residential } \\
\text { BL } 2\end{array}$ & $\begin{array}{c}\text { Residential } \\
\text { BL } 3\end{array}$ & $\begin{array}{c}\text { Residential } \\
\text { BL } 4\end{array}$ & $\begin{array}{l}\text { CAA - All } \\
\text { Levels }\end{array}$ & CAA BL 1 & CAA BL 2 & CAA BL 3 & $\begin{array}{c}\mathrm{CAA}>\mathrm{BL} \\
3\end{array}$ \\
\hline Small Carnivores & $14.7 \%$ & $11.4 \%$ & $14.3 \%$ & $17.4 \%$ & $9.4 \%$ & $7.6 \%$ & $26.0 \%$ & $29.0 \%$ & $18.6 \%$ & $31.9 \%$ & $15.6 \%$ \\
\hline Hares & $4.5 \%$ & $4.4 \%$ & $6.4 \%$ & $4.5 \%$ & $2.8 \%$ & $4.7 \%$ & $4.5 \%$ & $6.0 \%$ & $2.9 \%$ & $2.4 \%$ & $1.1 \%$ \\
\hline Rodents & $0.9 \%$ & $0.9 \%$ & $1.0 \%$ & $0.3 \%$ & $0.7 \%$ & $0.0 \%$ & $1.0 \%$ & $1.0 \%$ & $0.0 \%$ & $1.4 \%$ & $0.3 \%$ \\
\hline Birds & $14.0 \%$ & $14.5 \%$ & $19.0 \%$ & $16.7 \%$ & $9.9 \%$ & $21.6 \%$ & $10.7 \%$ & $10.1 \%$ & $1.4 \%$ & $16.4 \%$ & $10.4 \%$ \\
\hline Tortoises & $58.5 \%$ & $61.9 \%$ & $50.9 \%$ & $57.4 \%$ & $71.4 \%$ & $62.6 \%$ & $48.6 \%$ & $37.7 \%$ & $76.4 \%$ & $47.3 \%$ & $71.8 \%$ \\
\hline Fish \& Others & $7.5 \%$ & $6.8 \%$ & $8.3 \%$ & $3.7 \%$ & $5.7 \%$ & $3.5 \%$ & $9.2 \%$ & $16.2 \%$ & $0.7 \%$ & $0.5 \%$ & $0.8 \%$ \\
\hline Small Game & $32.1 \%$ & $40.9 \%$ & $40.6 \%$ & $43.3 \%$ & $46.9 \%$ & $38.5 \%$ & $15.5 \%$ & $15.9 \%$ & $15.6 \%$ & $31.4 \%$ & $21.2 \%$ \\
\hline Gazelle & $0.0 \%$ & $0.0 \%$ & $0.0 \%$ & $0.0 \%$ & $0.0 \%$ & $0.0 \%$ & $0.0 \%$ & $0.0 \%$ & $0.0 \%$ & $0.0 \%$ & $0.0 \%$ \\
\hline $\mathrm{O} / \mathrm{C}$ & $48.9 \%$ & $46.3 \%$ & $47.0 \%$ & $42.8 \%$ & $46.5 \%$ & $37.2 \%$ & $52.1 \%$ & $52.5 \%$ & $35.3 \%$ & $52.5 \%$ & $46.9 \%$ \\
\hline Bos & $0.8 \%$ & $0.5 \%$ & $1.4 \%$ & $0.1 \%$ & $0.0 \%$ & $0.0 \%$ & $1.2 \%$ & $1.2 \%$ & $0.1 \%$ & $0.0 \%$ & $0.5 \%$ \\
\hline Cervid & $25.0 \%$ & $30.6 \%$ & $26.8 \%$ & $38.5 \%$ & $31.3 \%$ & $37.5 \%$ & $18.4 \%$ & $15.2 \%$ & $48.6 \%$ & $31.4 \%$ & $32.2 \%$ \\
\hline Sus & $25.4 \%$ & $22.6 \%$ & $24.8 \%$ & $18.6 \%$ & $22.2 \%$ & $25.3 \%$ & $28.3 \%$ & $31.0 \%$ & $15.9 \%$ & $16.1 \%$ & $20.4 \%$ \\
\hline Large Artiodactyls & $66.5 \%$ & $57.8 \%$ & $57.9 \%$ & $55.6 \%$ & $52.2 \%$ & $60.6 \%$ & $82.8 \%$ & $82.4 \%$ & $83.7 \%$ & $66.1 \%$ & $75.8 \%$ \\
\hline Large Carnivores & $1.5 \%$ & $1.3 \%$ & $1.5 \%$ & $1.1 \%$ & $1.0 \%$ & $0.9 \%$ & $1.8 \%$ & $1.7 \%$ & $0.8 \%$ & $2.6 \%$ & $3.1 \%$ \\
\hline Total NISP & 53341 & 32713 & 10703 & 1380 & 6555 & 444 & 19422 & 9416 & 900 & 660 & 2912 \\
\hline
\end{tabular}


Table 8: Proportions of quick (lepus and birds) and slow (tortoise) small game

\begin{tabular}{|l|r|r|r|}
\hline Location & $\begin{array}{r}\text { Residential } \\
\text { BL 1 }\end{array}$ & \multicolumn{1}{|c|}{$\begin{array}{c}\text { Residential } \\
\text { BL 2 }\end{array}$} & \multicolumn{1}{|c|}{$\begin{array}{c}\text { Residential } \\
\text { BL 3 }\end{array}$} \\
\hline Lepus & $8.4 \%$ & $5.7 \%$ & $3.3 \%$ \\
\hline Bird & $24.9 \%$ & $21.3 \%$ & $11.8 \%$ \\
\hline Tortoise & $66.7 \%$ & $73.0 \%$ & $84.9 \%$ \\
\hline Total NISP & 3313 & 470 & 2584 \\
\hline
\end{tabular}


Table 9: Elements by skeletal region in standard bird. Based on element counts of a Bald Eagle (Haliaeatus leucocephalus).

\begin{tabular}{|c|c|c|c|c|}
\hline Region & Element & Number & $\begin{array}{l}\text { Region } \\
\text { Number }\end{array}$ & Region \\
\hline Skull & Various & 8 & 8 & $6 \%$ \\
\hline \multirow{9}{*}{ Trunk } & Vertebra & 27 & \multirow{9}{*}{68} & \multirow{9}{*}{$52 \%$} \\
\hline & Ribs & 30 & & \\
\hline & Scapula & 2 & & \\
\hline & Coracoid & 2 & & \\
\hline & Furcula & 1 & & \\
\hline & Sternum & 1 & & \\
\hline & P Humerus & 2 & & \\
\hline & Femur & 2 & & \\
\hline & Pelvis & 1 & & \\
\hline \multirow{2}{*}{ Leg } & Tibiotarsus & 2 & \multirow{2}{*}{4} & \multirow{2}{*}{$3 \%$} \\
\hline & Fibula & 2 & & \\
\hline \multirow{6}{*}{ Wing } & D Humerus & 2 & \multirow{6}{*}{20} & \multirow{6}{*}{$15 \%$} \\
\hline & Radius & 2 & & \\
\hline & Ulna & 2 & & \\
\hline & Carpometacarpus & 2 & & \\
\hline & Carpals & 4 & & \\
\hline & Manual Phalanges & 8 & & \\
\hline \multirow{4}{*}{ Feet } & Tarsometatarsus & 2 & \multirow{4}{*}{32} & \multirow{4}{*}{$24 \%$} \\
\hline & Metatarsals & 2 & & \\
\hline & Pedal Phalanges & 20 & & \\
\hline & Ungual Phalanges & 8 & & \\
\hline
\end{tabular}


Table 10: Hallan Çemi avifauna by body part

\begin{tabular}{|c|c|c|c|c|c|c|}
\hline Type & Part & Whole Site & Residential & CAA & House 1B & $\begin{array}{c}\text { Other BL } 1 \\
\text { Houses }\end{array}$ \\
\hline \multirow{6}{*}{ Large Gamebird } & Head & $0.0 \%$ & $0.0 \%$ & $0.0 \%$ & $0.0 \%$ & $0.0 \%$ \\
\hline & Trunk & $38.7 \%$ & $34.1 \%$ & $50.0 \%$ & $53.8 \%$ & $47.1 \%$ \\
\hline & Leg & $20.9 \%$ & $17.8 \%$ & $32.0 \%$ & $7.7 \%$ & $11.8 \%$ \\
\hline & Wing & $13.6 \%$ & $14.1 \%$ & $12.0 \%$ & $15.4 \%$ & $17.6 \%$ \\
\hline & Foot & $26.7 \%$ & $34.1 \%$ & $6.0 \%$ & $23.1 \%$ & $23.5 \%$ \\
\hline & Total NISP & 191 & 135 & 50 & 13 & 17 \\
\hline \multirow{6}{*}{ Small Gamebird } & Head & $0.0 \%$ & $0.0 \%$ & $0.0 \%$ & $0.0 \%$ & $0.0 \%$ \\
\hline & Trunk & $47.1 \%$ & $49.2 \%$ & $47.6 \%$ & $51.1 \%$ & $45.2 \%$ \\
\hline & Leg & $42.0 \%$ & $42.0 \%$ & $42.9 \%$ & $44.7 \%$ & $45.2 \%$ \\
\hline & Wing & $7.1 \%$ & $4.6 \%$ & $4.8 \%$ & $2.1 \%$ & $7.1 \%$ \\
\hline & Foot & $3.7 \%$ & $4.3 \%$ & $4.8 \%$ & $2.1 \%$ & $2.4 \%$ \\
\hline & Total NISP & 350 & 305 & 21 & 47 & 42 \\
\hline \multirow{6}{*}{ Crow } & Head & $0.0 \%$ & $0.0 \%$ & $0.0 \%$ & $0.0 \%$ & $0.0 \%$ \\
\hline & Trunk & $6.5 \%$ & $3.3 \%$ & $20.0 \%$ & $0.0 \%$ & $0.0 \%$ \\
\hline & Leg & $8.7 \%$ & $0.0 \%$ & $40.0 \%$ & $0.0 \%$ & $0.0 \%$ \\
\hline & Wing & $63.0 \%$ & $73.3 \%$ & $30.0 \%$ & $50.0 \%$ & $100.0 \%$ \\
\hline & Foot & $21.7 \%$ & $23.3 \%$ & $10.0 \%$ & $50.0 \%$ & $0.0 \%$ \\
\hline & NISP & 46 & 30 & 10 & 6 & 2 \\
\hline \multirow{6}{*}{ Large Raptor } & Head & $0.0 \%$ & $0.0 \%$ & $0.0 \%$ & $0.0 \%$ & $0.0 \%$ \\
\hline & Trunk & $4.9 \%$ & $4.7 \%$ & $5.6 \%$ & $0.0 \%$ & $0.0 \%$ \\
\hline & Leg & $12.5 \%$ & $14.1 \%$ & $9.3 \%$ & $11.1 \%$ & $14.3 \%$ \\
\hline & Wing & $22.2 \%$ & $27.1 \%$ & $13.0 \%$ & $33.3 \%$ & $14.3 \%$ \\
\hline & Foot & $60.4 \%$ & $54.1 \%$ & $72.2 \%$ & $55.6 \%$ & $71.4 \%$ \\
\hline & Total NISP & 144 & 85 & 54 & 9 & 7 \\
\hline Small Raptor & Head & $0.0 \%$ & $0.0 \%$ & $0.0 \%$ & $0.0 \%$ & $0.0 \%$ \\
\hline
\end{tabular}




\begin{tabular}{|c|c|c|c|c|c|c|}
\hline & Trunk & $6.4 \%$ & $12.8 \%$ & $18.2 \%$ & $25.0 \%$ & $0.0 \%$ \\
\hline & Leg & $8.6 \%$ & $10.6 \%$ & $9.1 \%$ & $0.0 \%$ & $0.0 \%$ \\
\hline & Wing & $71.7 \%$ & $53.2 \%$ & $54.5 \%$ & $75.0 \%$ & $100.0 \%$ \\
\hline & Foot & $13.3 \%$ & $23.4 \%$ & $18.2 \%$ & $0.0 \%$ & $0.0 \%$ \\
\hline & NISP & 59 & 47 & 11 & 4 & 1 \\
\hline \multirow{6}{*}{ Large Waterfowl } & Head & $0.5 \%$ & $0.6 \%$ & $0.0 \%$ & $2.8 \%$ & $0.0 \%$ \\
\hline & Trunk & $29.6 \%$ & $30.0 \%$ & $30.6 \%$ & $27.8 \%$ & $52.9 \%$ \\
\hline & Leg & $6.8 \%$ & $6.9 \%$ & $8.3 \%$ & $5.6 \%$ & $17.6 \%$ \\
\hline & Wing & $35.9 \%$ & $32.5 \%$ & $41.7 \%$ & $47.2 \%$ & $5.9 \%$ \\
\hline & Foot & $27.2 \%$ & $30.0 \%$ & $19.4 \%$ & $16.7 \%$ & $23.5 \%$ \\
\hline & Total NISP & 206 & 160 & 36 & 36 & 17 \\
\hline \multirow{6}{*}{ Small Waterfowl } & Head & $0.0 \%$ & $0.0 \%$ & $0.0 \%$ & $0.0 \%$ & $0.0 \%$ \\
\hline & Trunk & $45.1 \%$ & $42.4 \%$ & $66.7 \%$ & $37.5 \%$ & $44.4 \%$ \\
\hline & Leg & $21.1 \%$ & $22.0 \%$ & $33.3 \%$ & $25.0 \%$ & $44.4 \%$ \\
\hline & Wing & $13.5 \%$ & $25.4 \%$ & $0.0 \%$ & $25.0 \%$ & $11.1 \%$ \\
\hline & Foot & $8.5 \%$ & $10.2 \%$ & $0.0 \%$ & $12.5 \%$ & $0.0 \%$ \\
\hline & Total NISP & 71 & 59 & 3 & 8 & 9 \\
\hline \multirow{6}{*}{ Large Wader } & Head & $1.5 \%$ & $1.8 \%$ & $0.0 \%$ & $0.0 \%$ & $0.0 \%$ \\
\hline & Trunk & $22.1 \%$ & $14.5 \%$ & $58.3 \%$ & $33.3 \%$ & $12.5 \%$ \\
\hline & Leg & $5.9 \%$ & $7.3 \%$ & $0.0 \%$ & $0.0 \%$ & $12.5 \%$ \\
\hline & Wing & $29.4 \%$ & $27.3 \%$ & $33.3 \%$ & $33.3 \%$ & $37.5 \%$ \\
\hline & Foot & $41.2 \%$ & $49.1 \%$ & $8.3 \%$ & $33.3 \%$ & $37.5 \%$ \\
\hline & Total NISP & 68 & 55 & 12 & 3 & 11 \\
\hline \multirow{5}{*}{ Small Wader } & Head & $0.0 \%$ & $0.0 \%$ & $0.0 \%$ & $0.0 \%$ & $0.0 \%$ \\
\hline & Trunk & $20.0 \%$ & $20.0 \%$ & $0.0 \%$ & $0.0 \%$ & $0.0 \%$ \\
\hline & Leg & $0.0 \%$ & $0.0 \%$ & $0.0 \%$ & $0.0 \%$ & $0.0 \%$ \\
\hline & Wing & $80.0 \%$ & $80.0 \%$ & $0.0 \%$ & $0.0 \%$ & $0.0 \%$ \\
\hline & Foot & $0.0 \%$ & $0.0 \%$ & $0.0 \%$ & $0.0 \%$ & $0.0 \%$ \\
\hline
\end{tabular}




\begin{tabular}{|l|l|r|r|r|r|r|} 
& Total NISP & 5 & 5 & 0 & 0 & 0 \\
\hline \multirow{5}{*}{ Water Bird } & Head & $0.0 \%$ & $0.0 \%$ & $0.0 \%$ & $0.0 \%$ & $0.0 \%$ \\
\cline { 2 - 7 } & Trunk & $23.1 \%$ & $273.0 \%$ & $0.0 \%$ & $0.0 \%$ & $0.0 \%$ \\
\cline { 2 - 7 } & Leg & $23.1 \%$ & $27.3 \%$ & $0.0 \%$ & $100.0 \%$ & $0.0 \%$ \\
\cline { 2 - 7 } & Wing & $23.1 \%$ & $18.2 \%$ & $0.0 \%$ & $0.0 \%$ & $50.0 \%$ \\
\cline { 2 - 7 } & Foot & $30.8 \%$ & $27.3 \%$ & $0.0 \%$ & $0.0 \%$ & $50.0 \%$ \\
\cline { 2 - 7 } & Total NISP & 13 & 11 & 0 & 1 & 2 \\
\hline
\end{tabular}




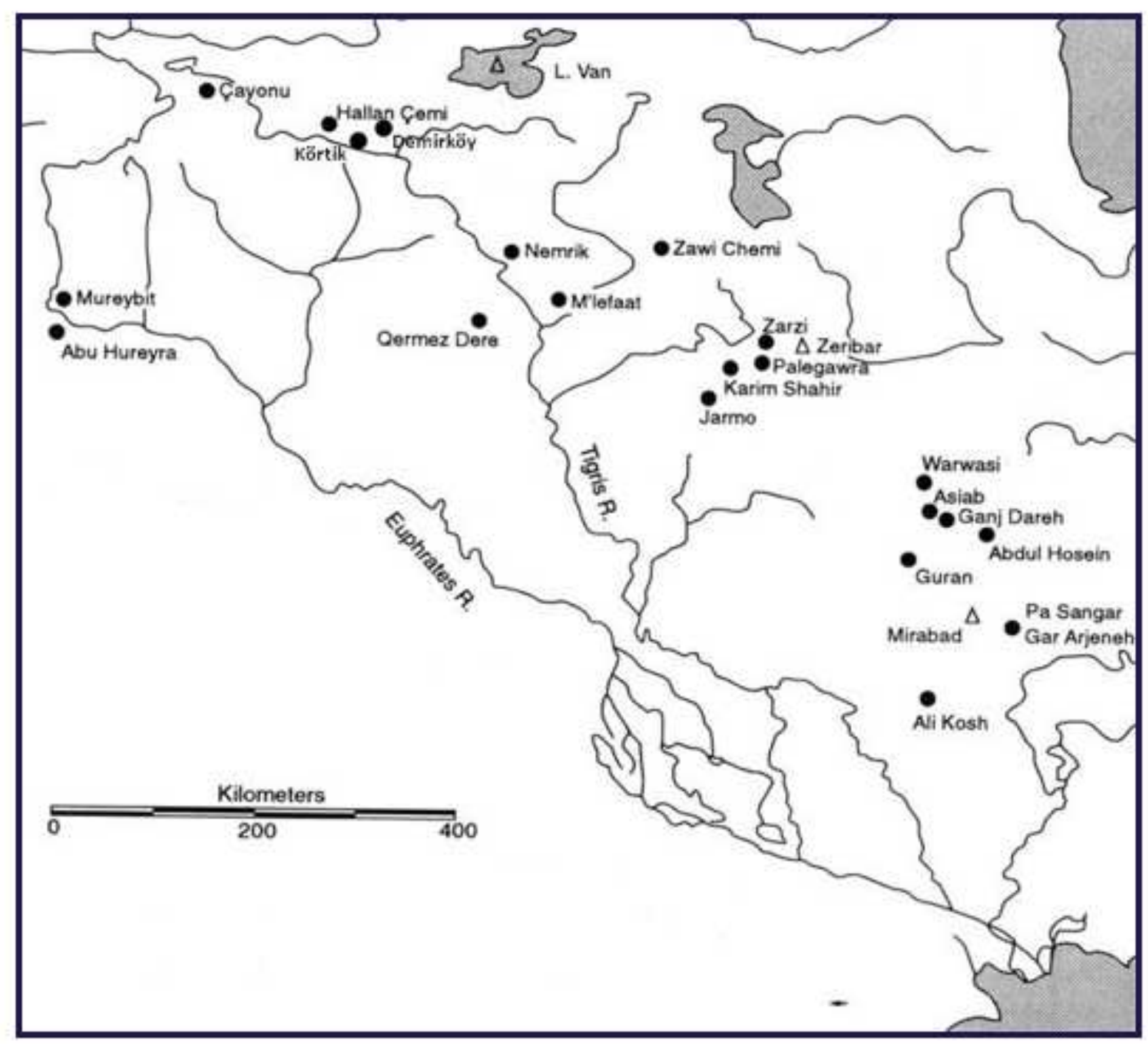




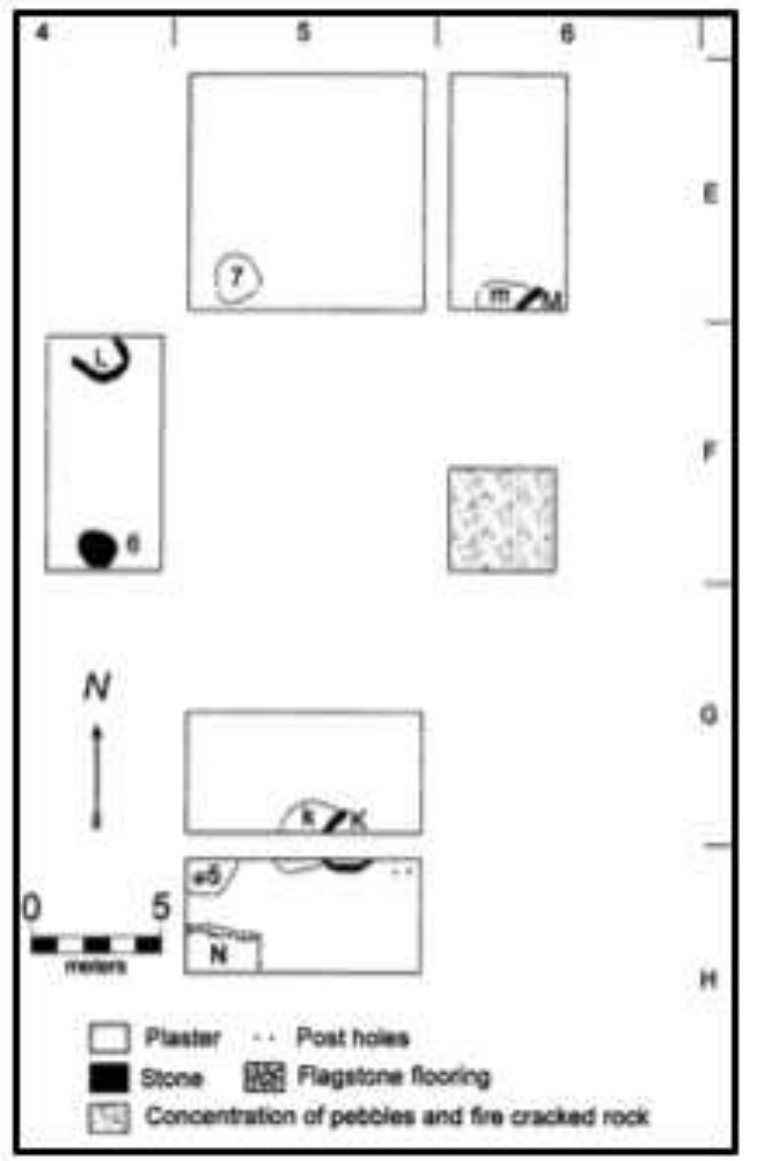

a.

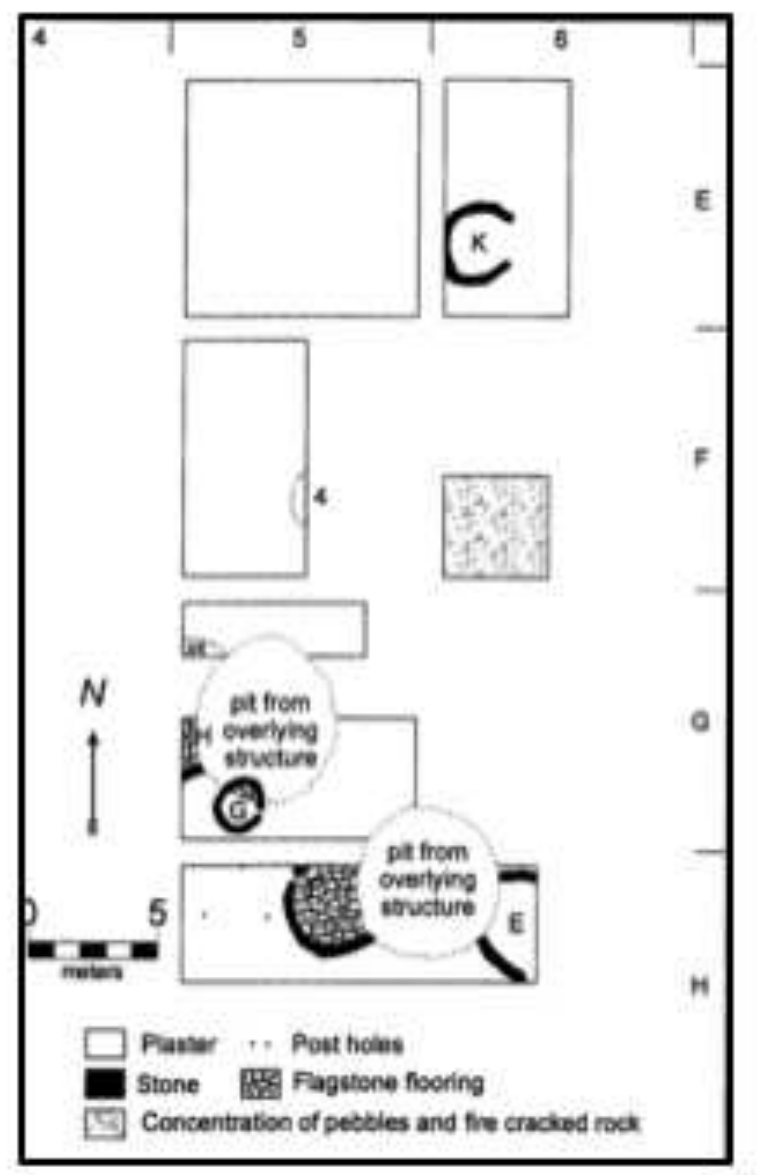

b.

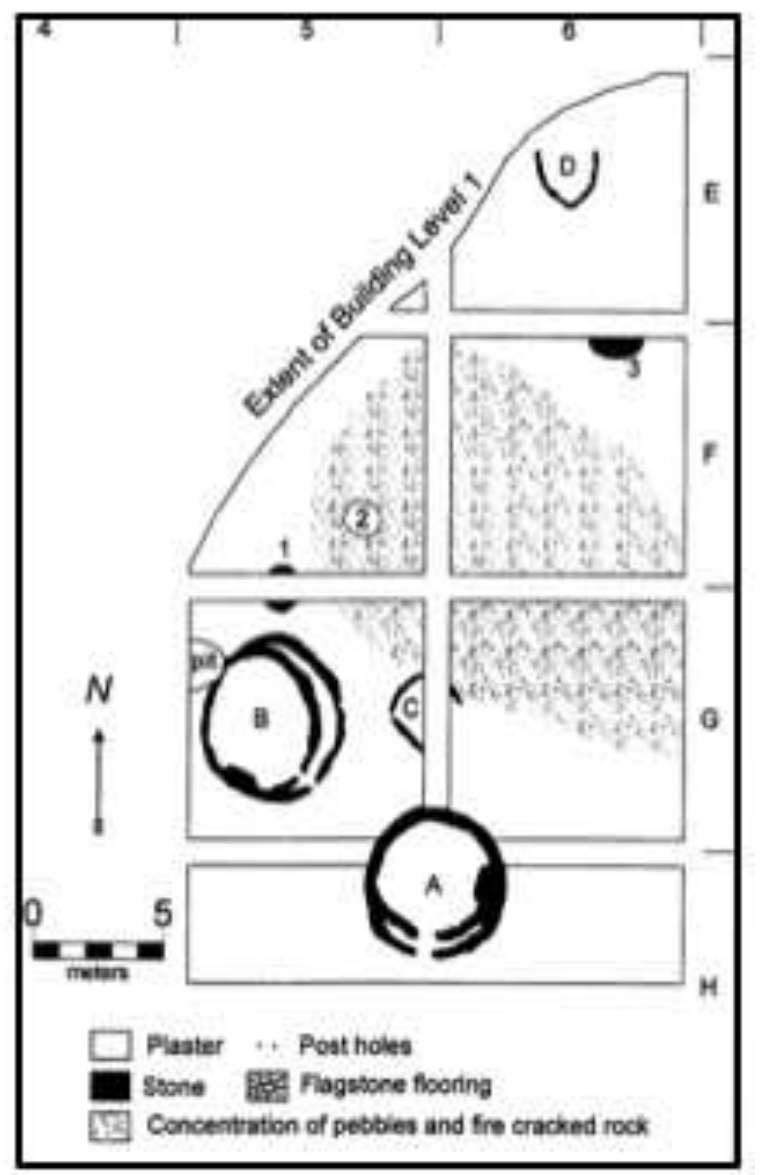

c. 

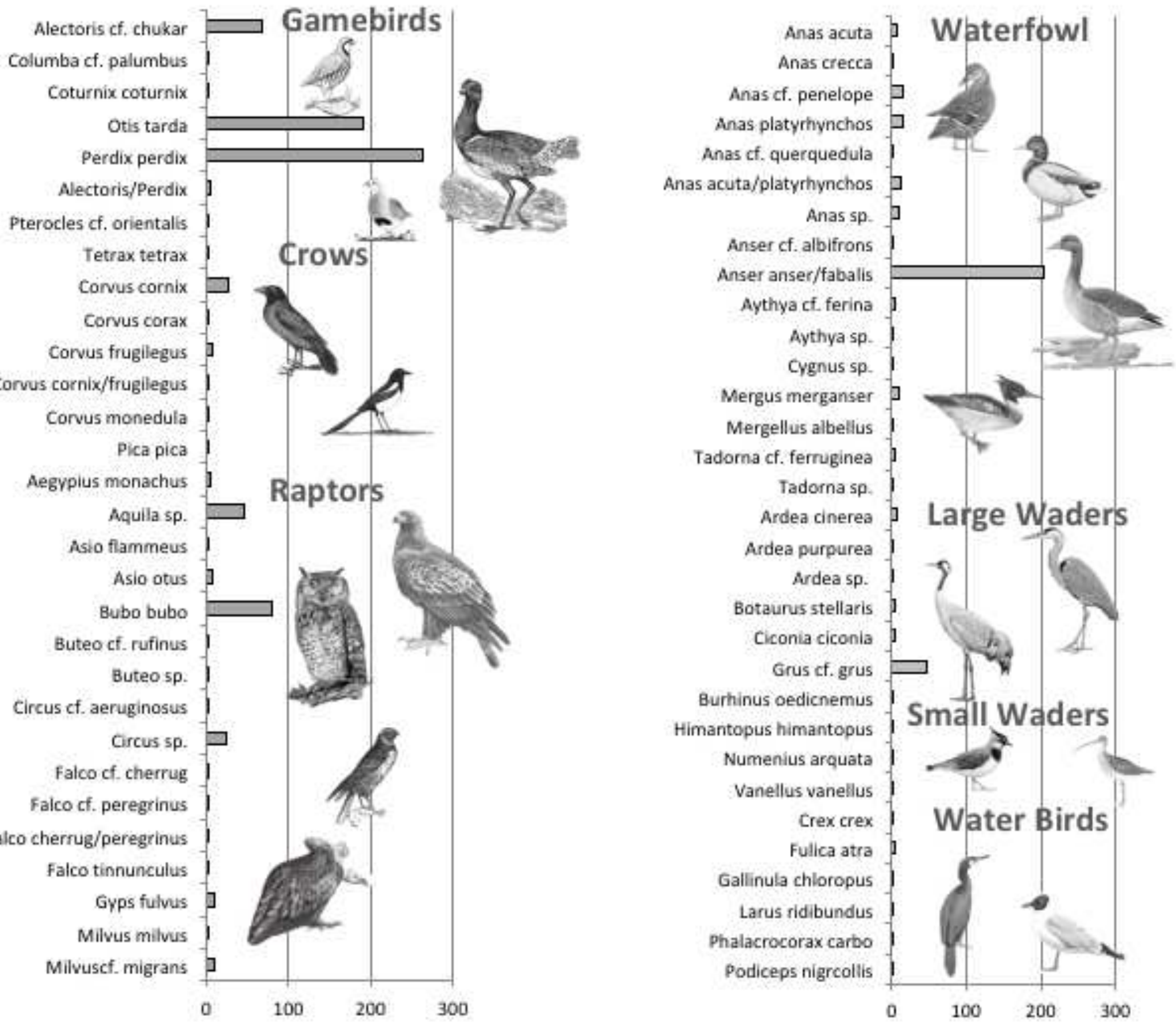

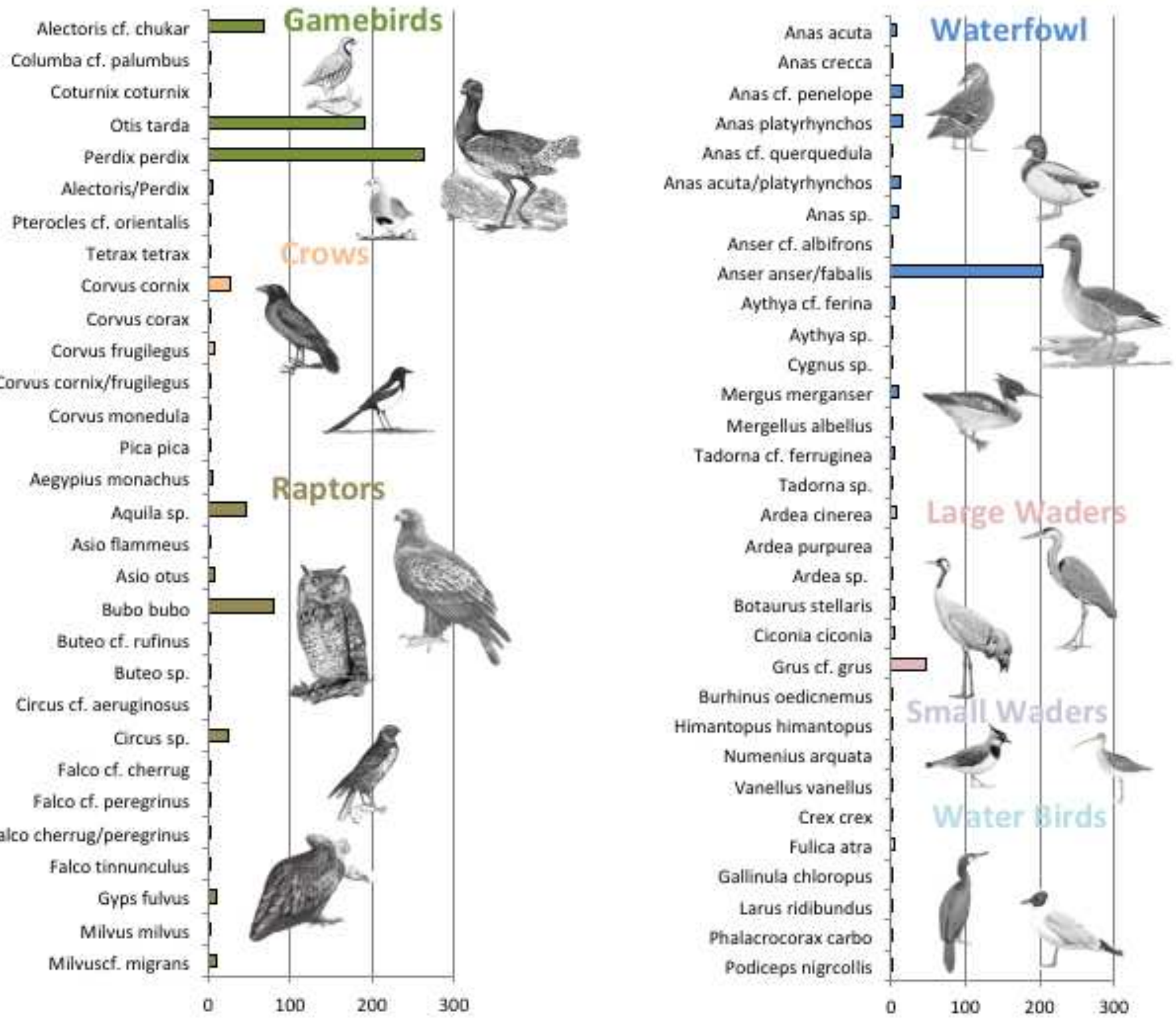


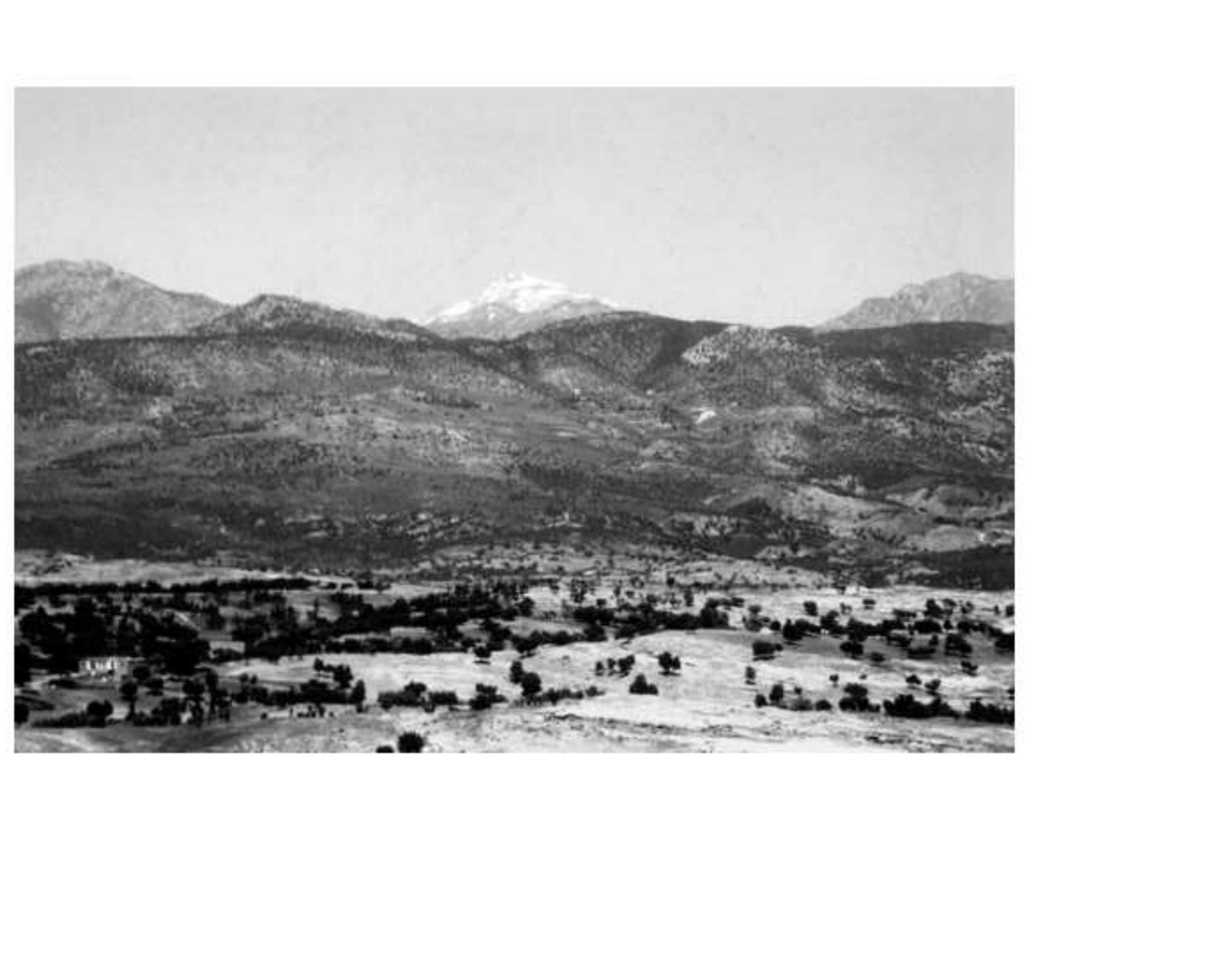

.
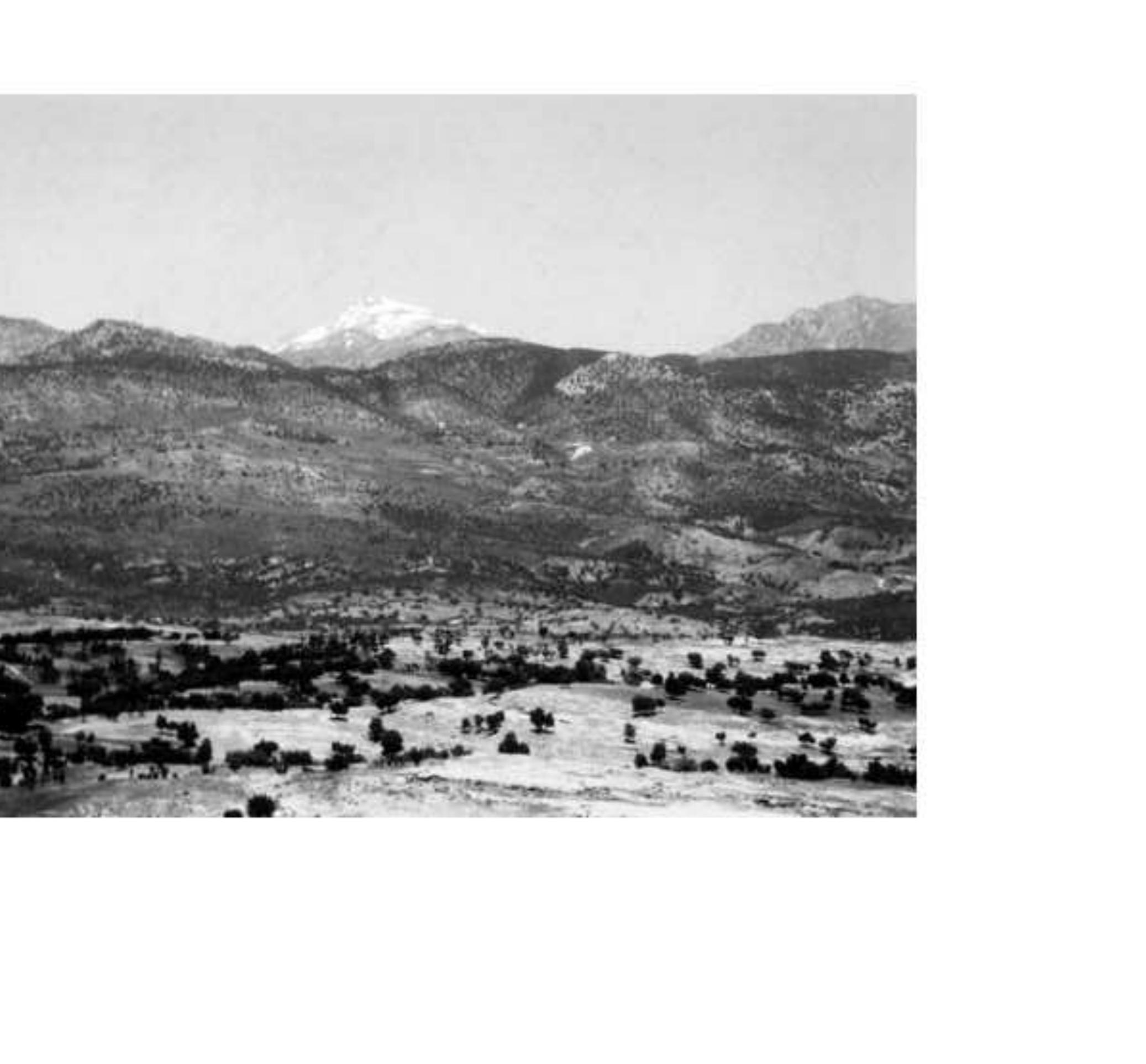


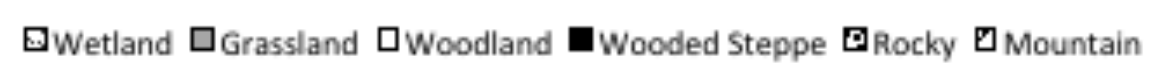

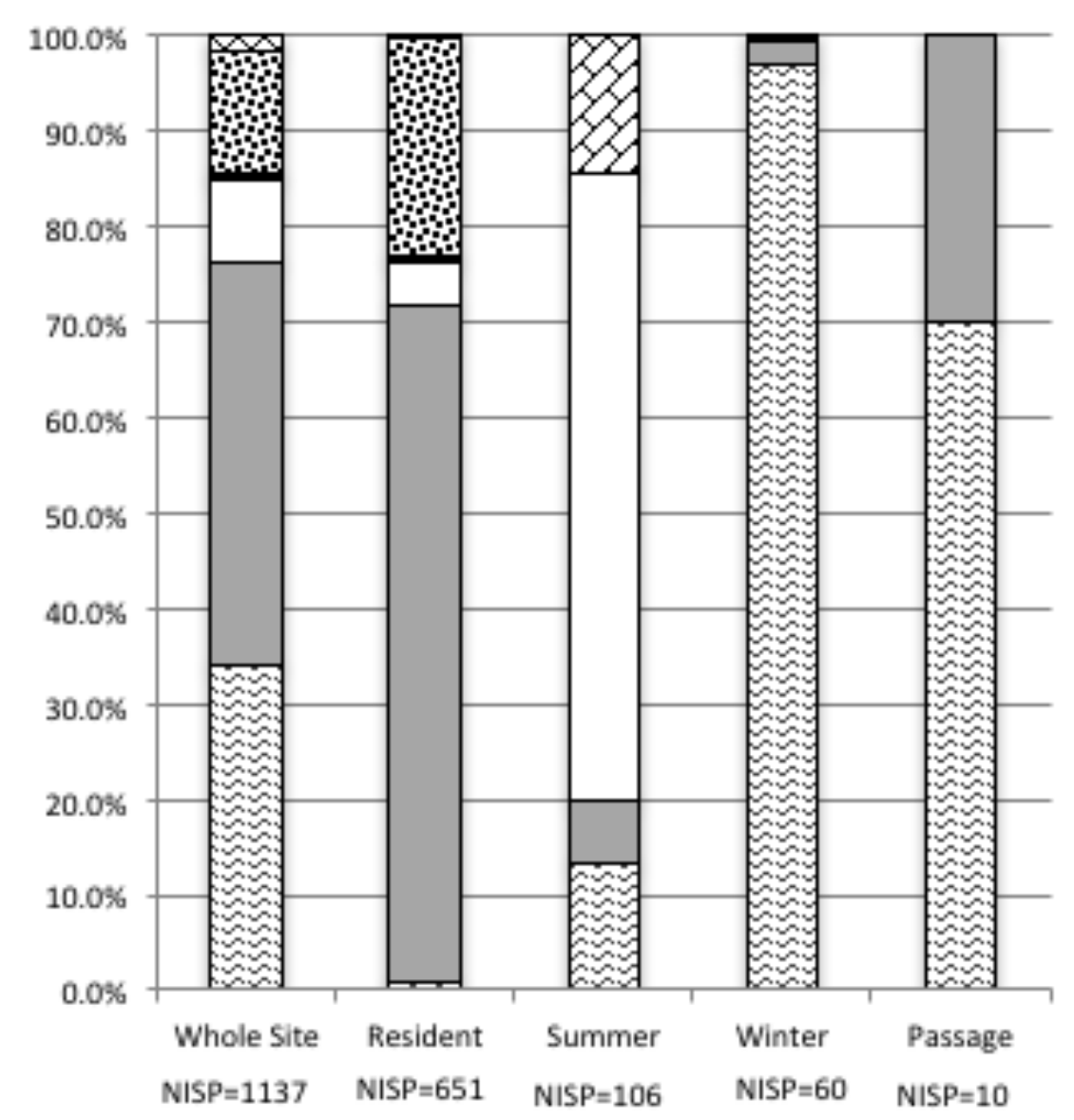

$\square_{\text {Winter }} \square_{\text {Spring/Autumn }} \square_{\text {Summer }}$

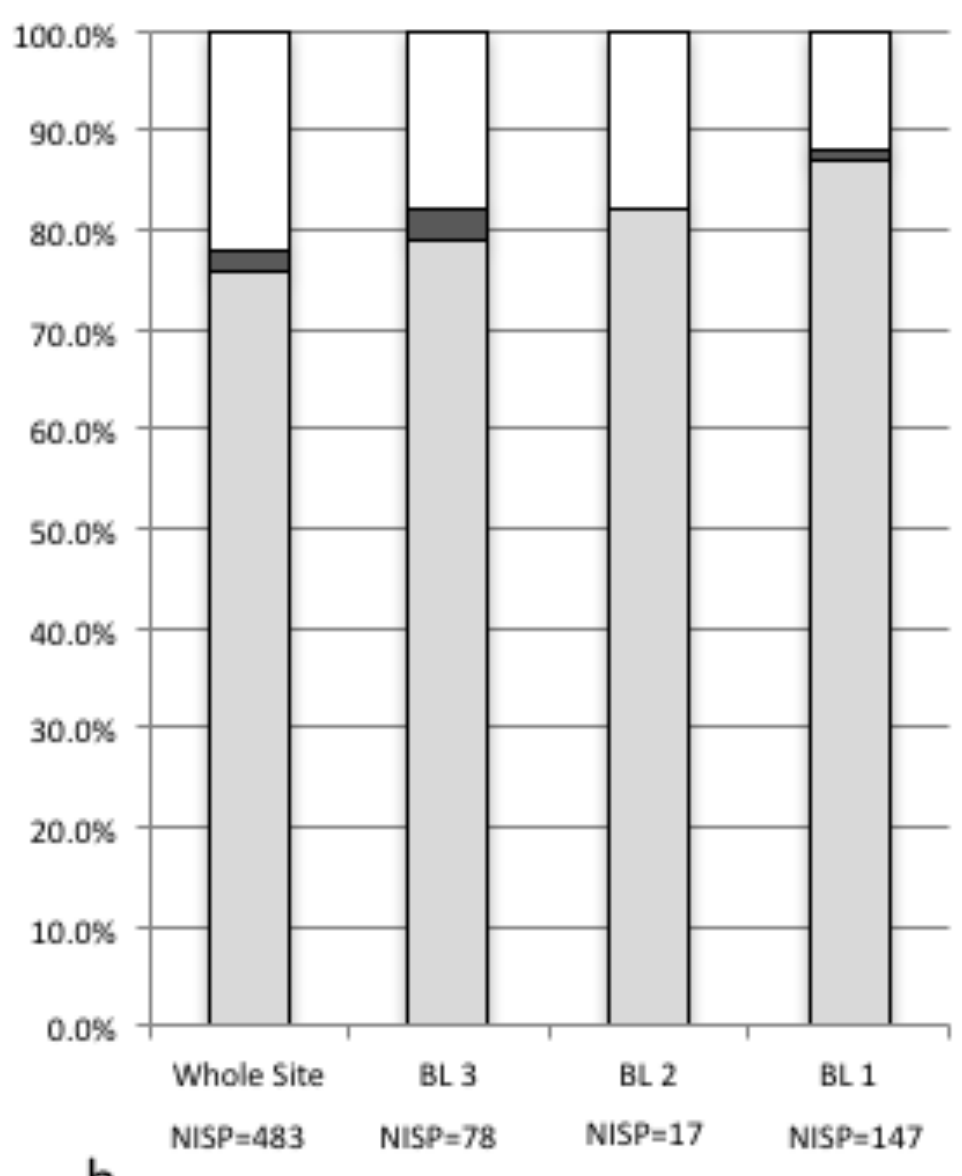

a.

b. 
$\square$ Wetland $\square$ Grassiand $\boldsymbol{\square}_{\text {Woodland }} \square$ Wooded Steppe $\square$ Rocky $\square$ Mountain

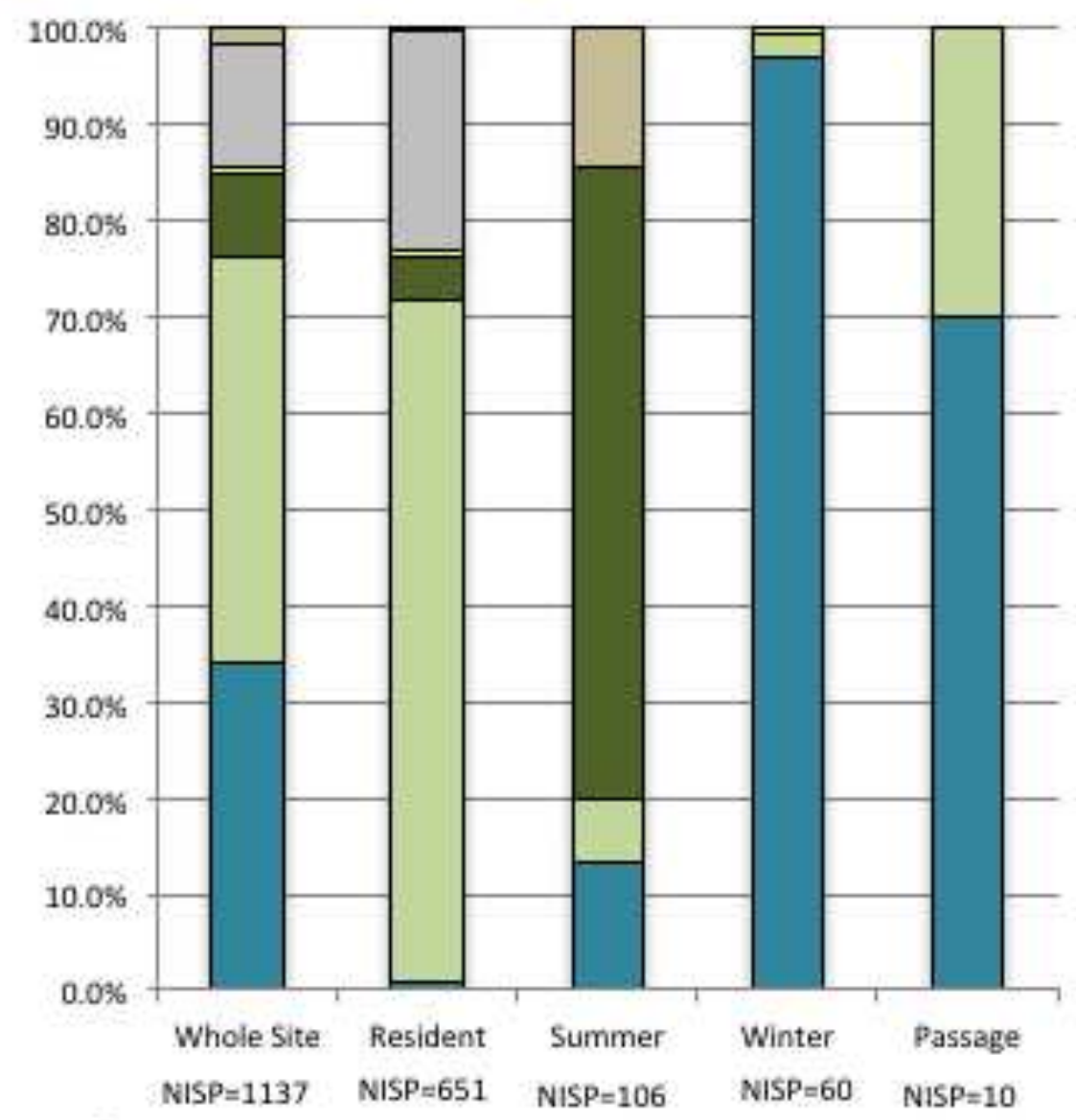

a. $\square$ Winter $\square_{\text {Sprin/Autumn }} \square_{\text {Summer }}$

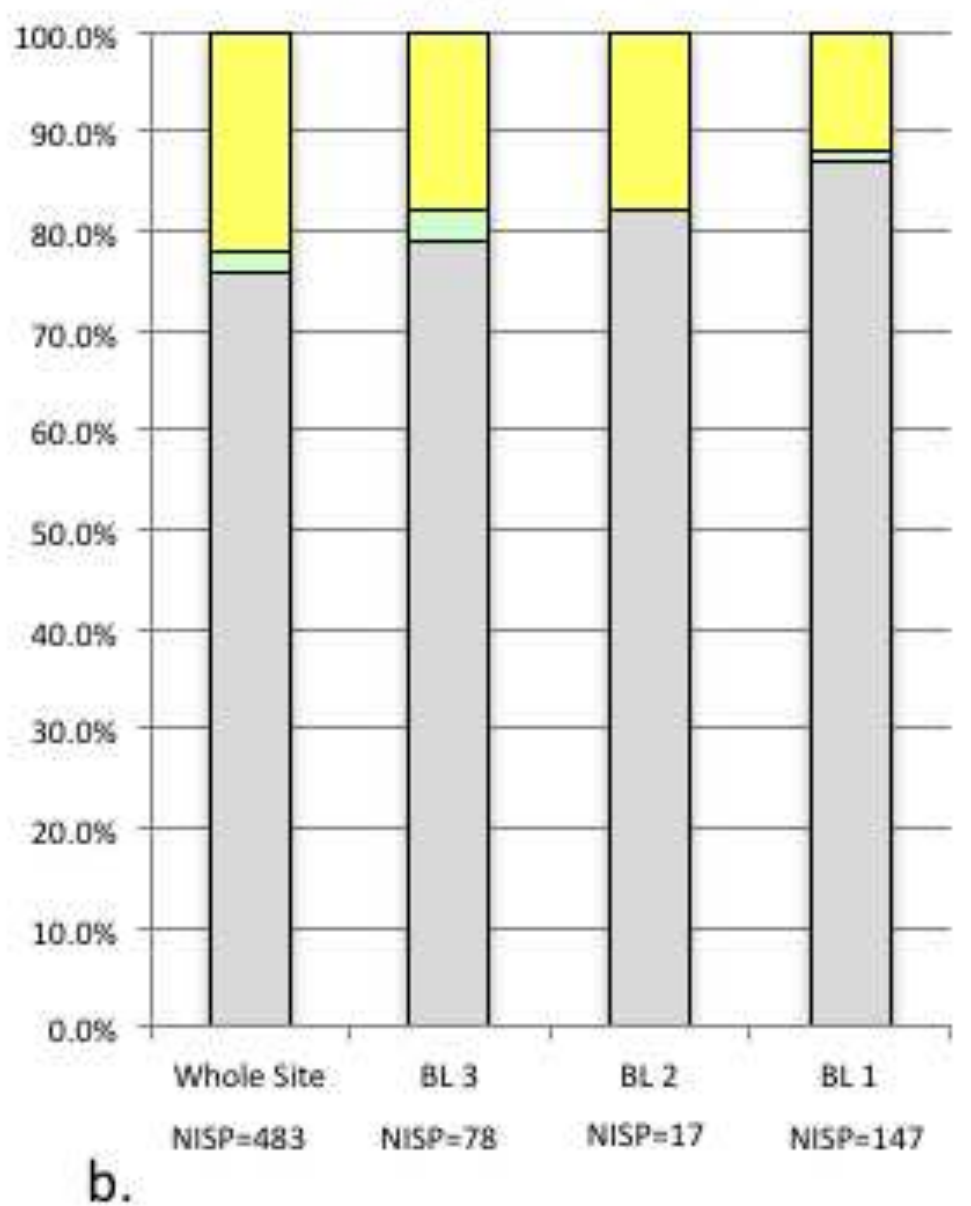




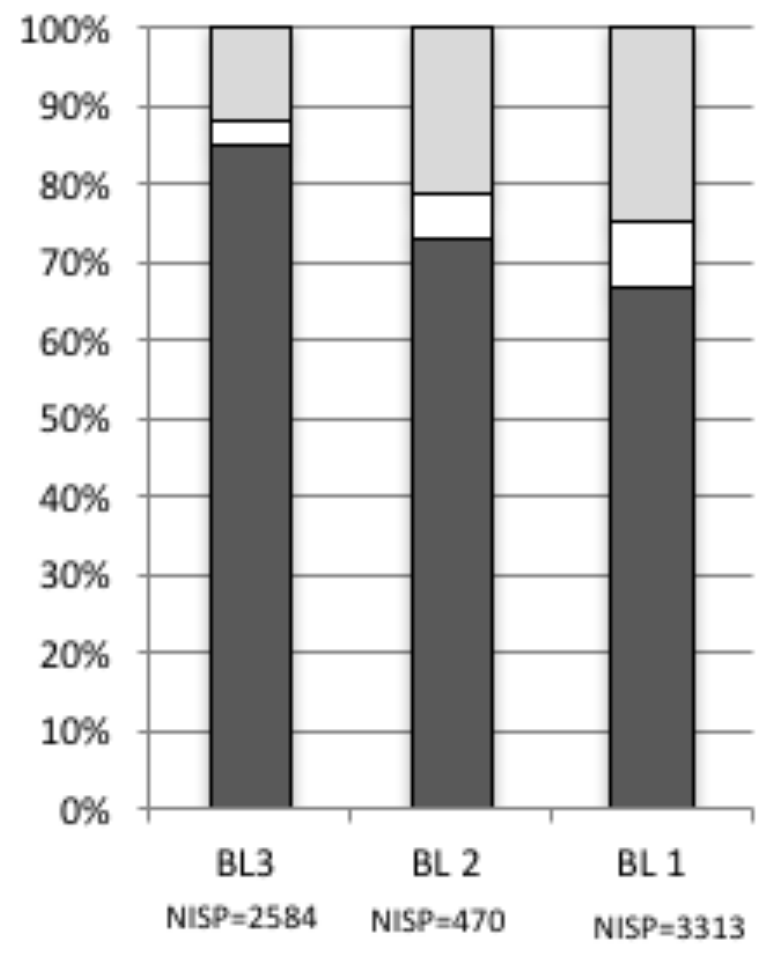

a.
口Bird

ㄴ.epus

口Tortoise

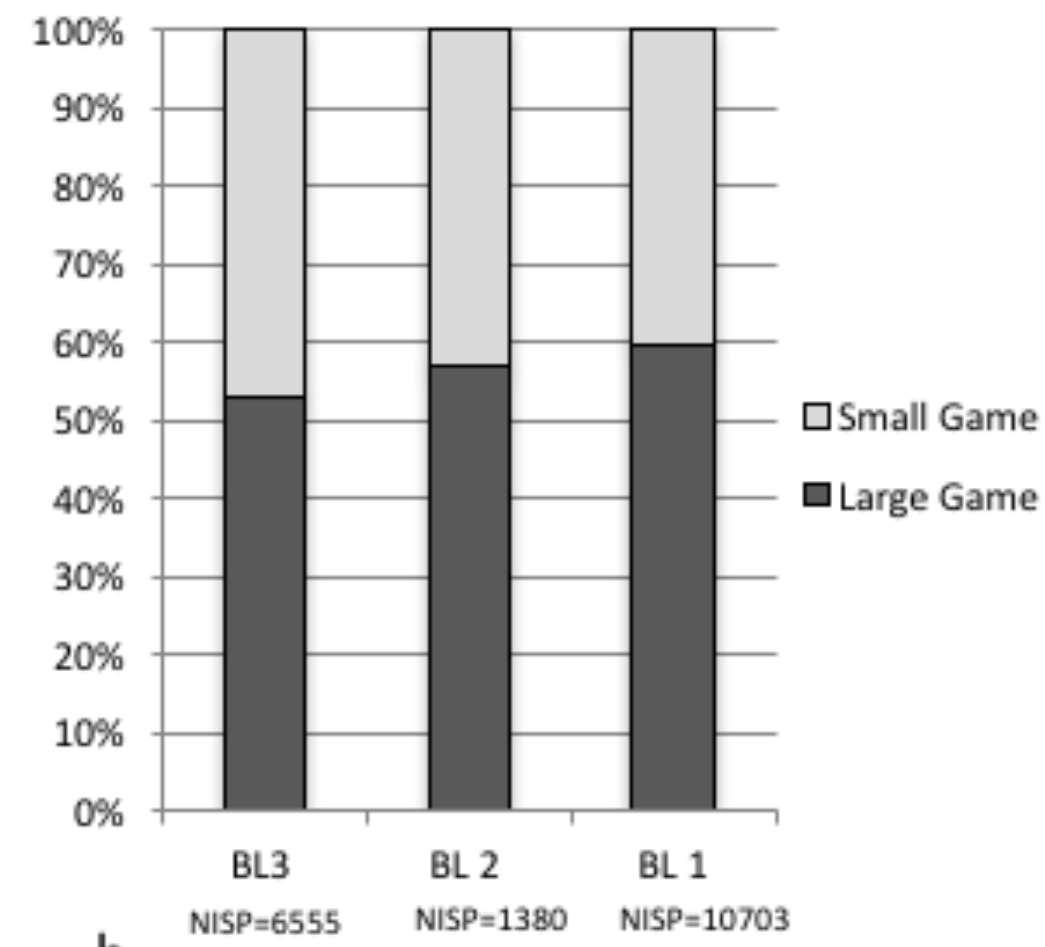

b. 


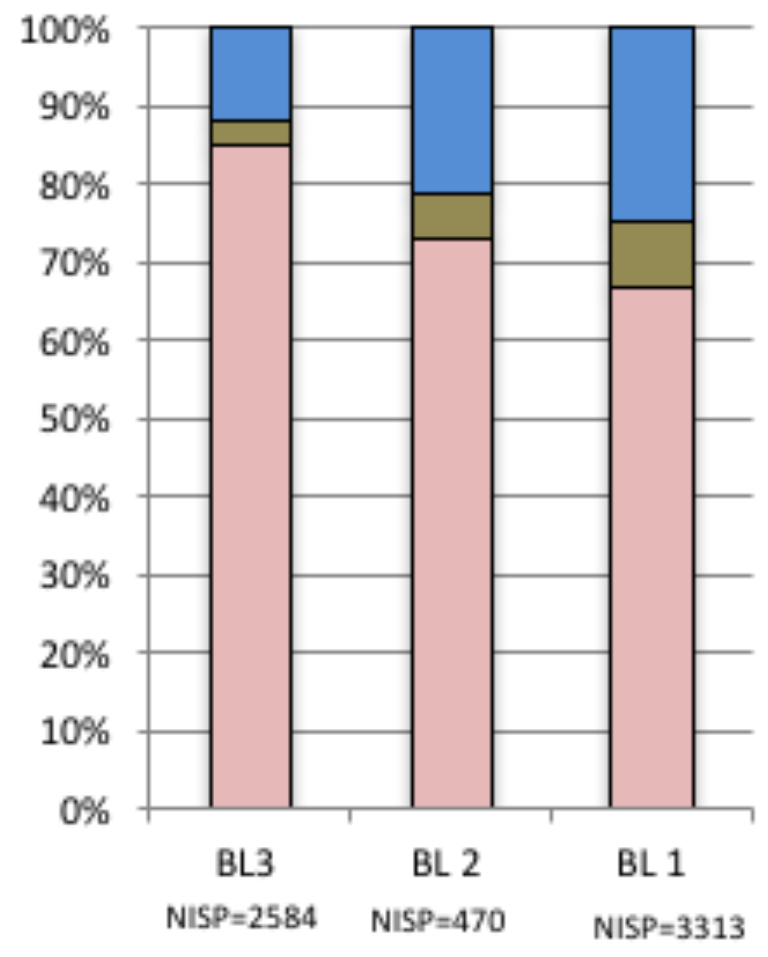

a.
口Bird

口Lepus

$\square$ Tortoise

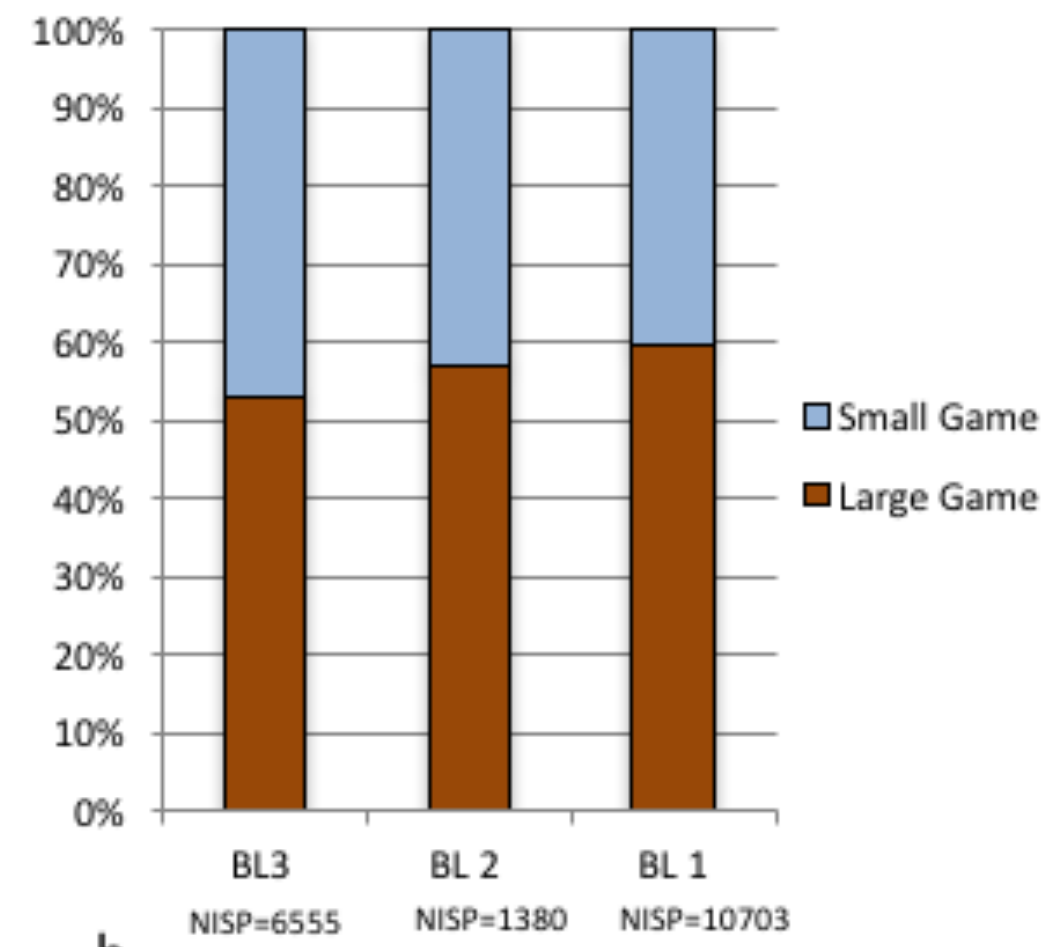

b. 


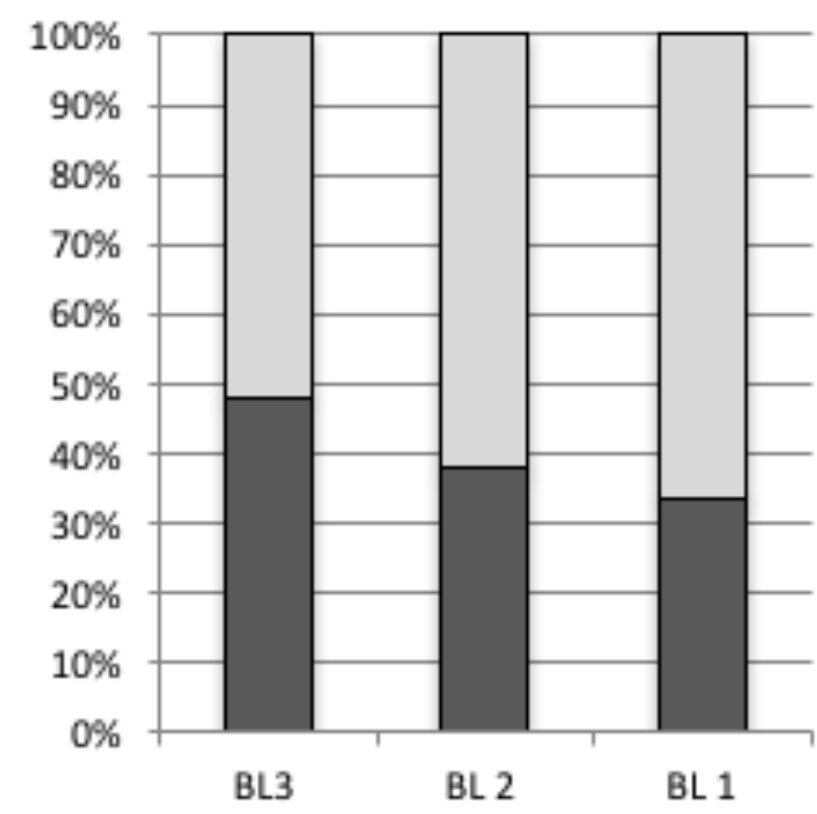

a. $\quad \mathrm{NISP}=111 \quad \mathrm{NISP}=29 \quad \mathrm{NISP}=287$

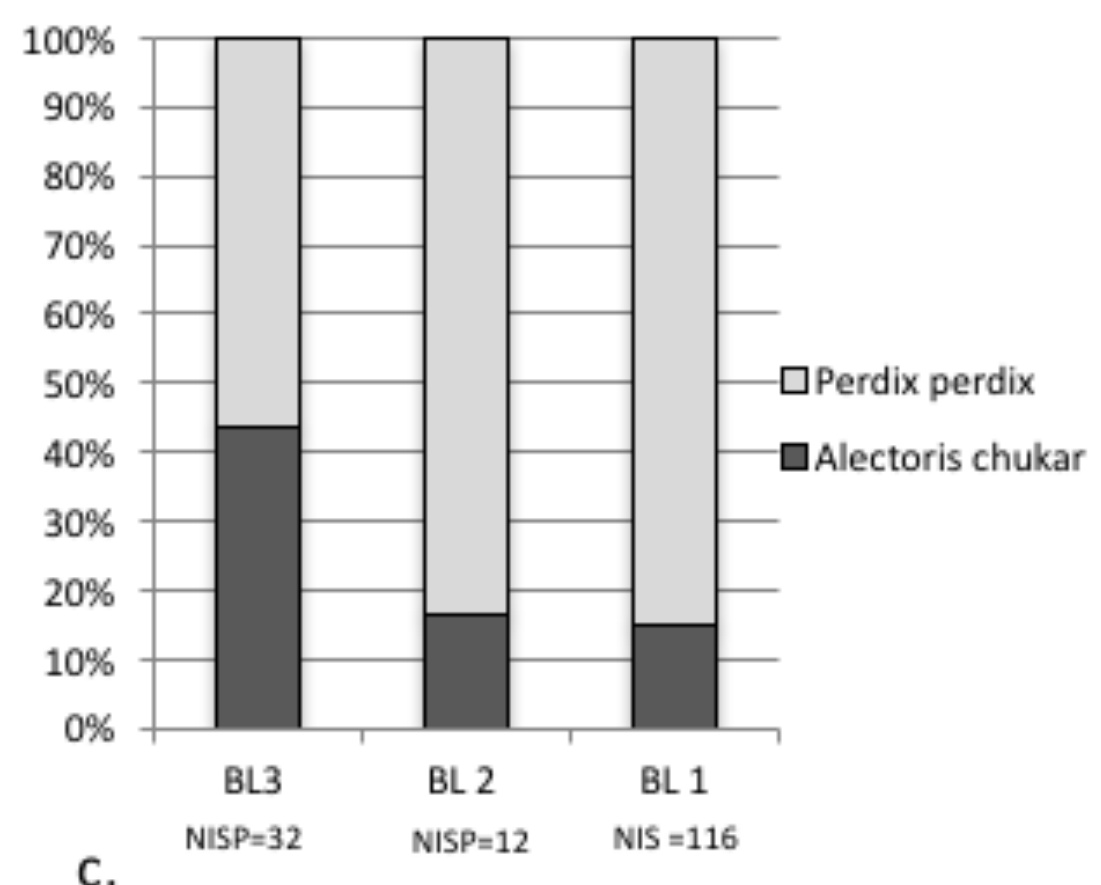

口Gamebirds

口Waterfowl

NISP $=12 \quad$ NIS $=116$
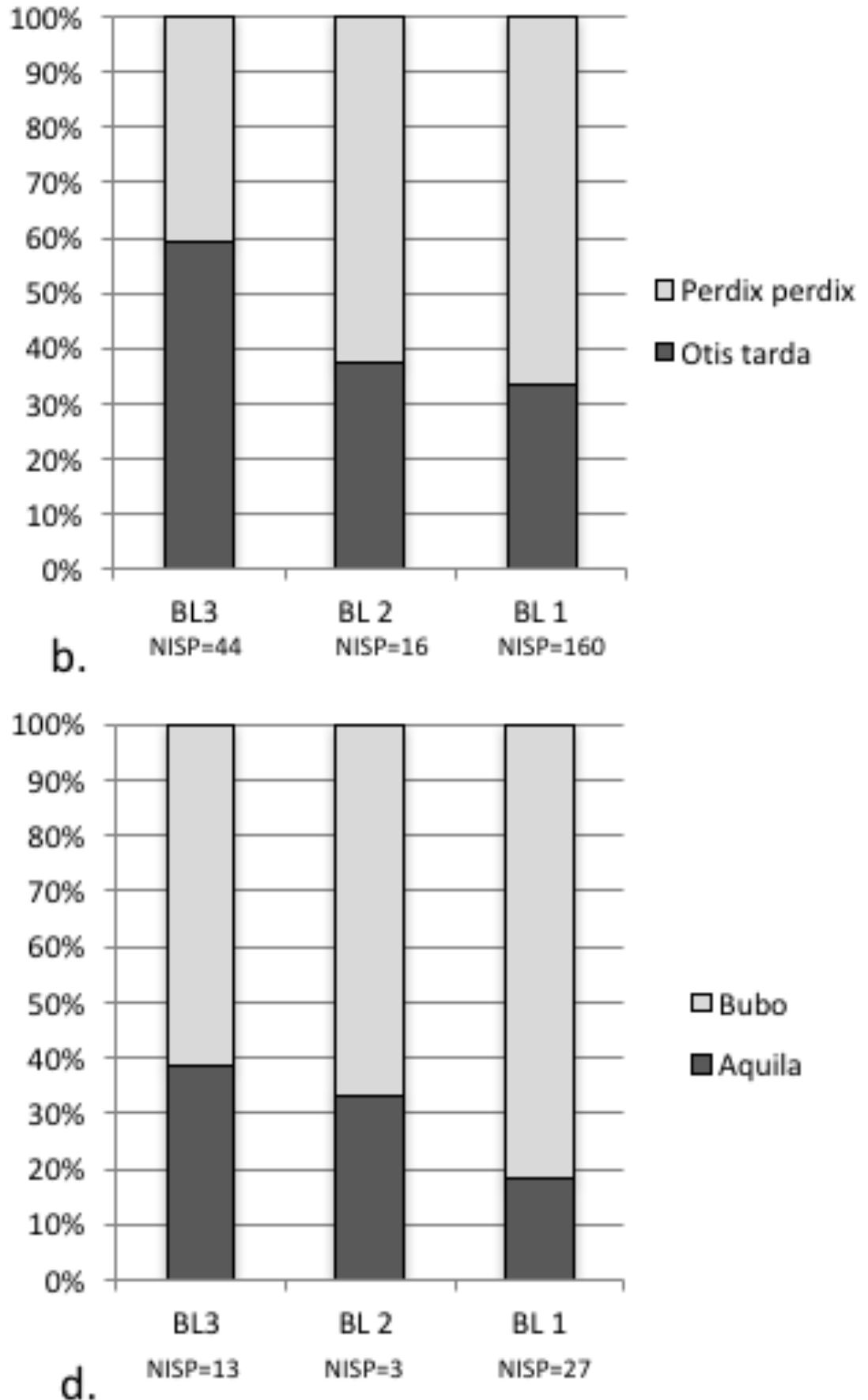

$\square$ Bubo

$\square$ Aquila 


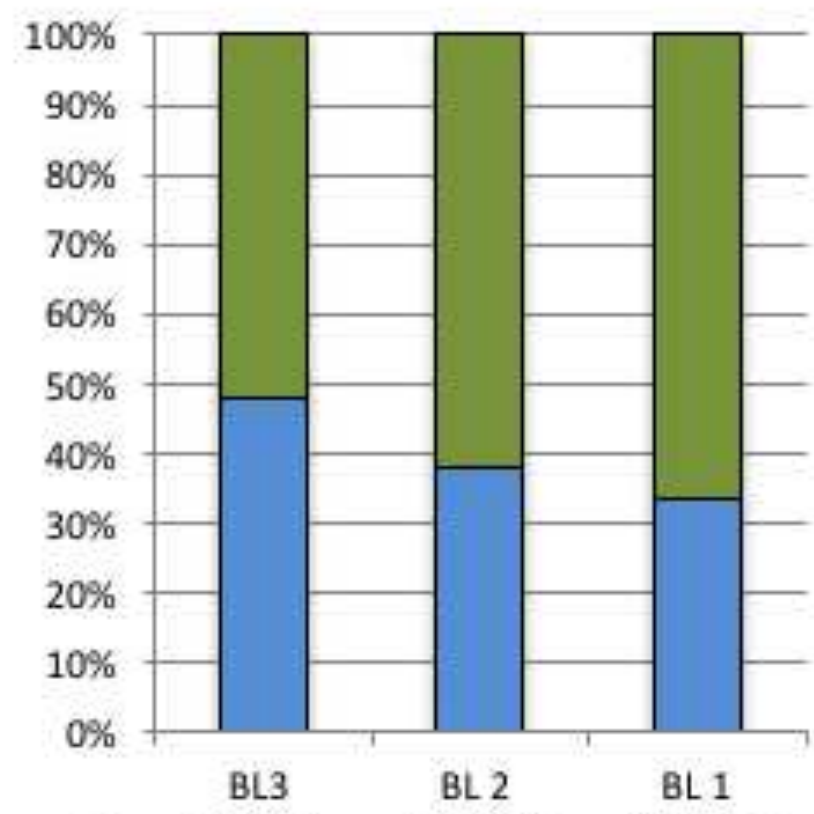

a. $N I S P=111 \quad N I S P=29 \quad N I S P=287$

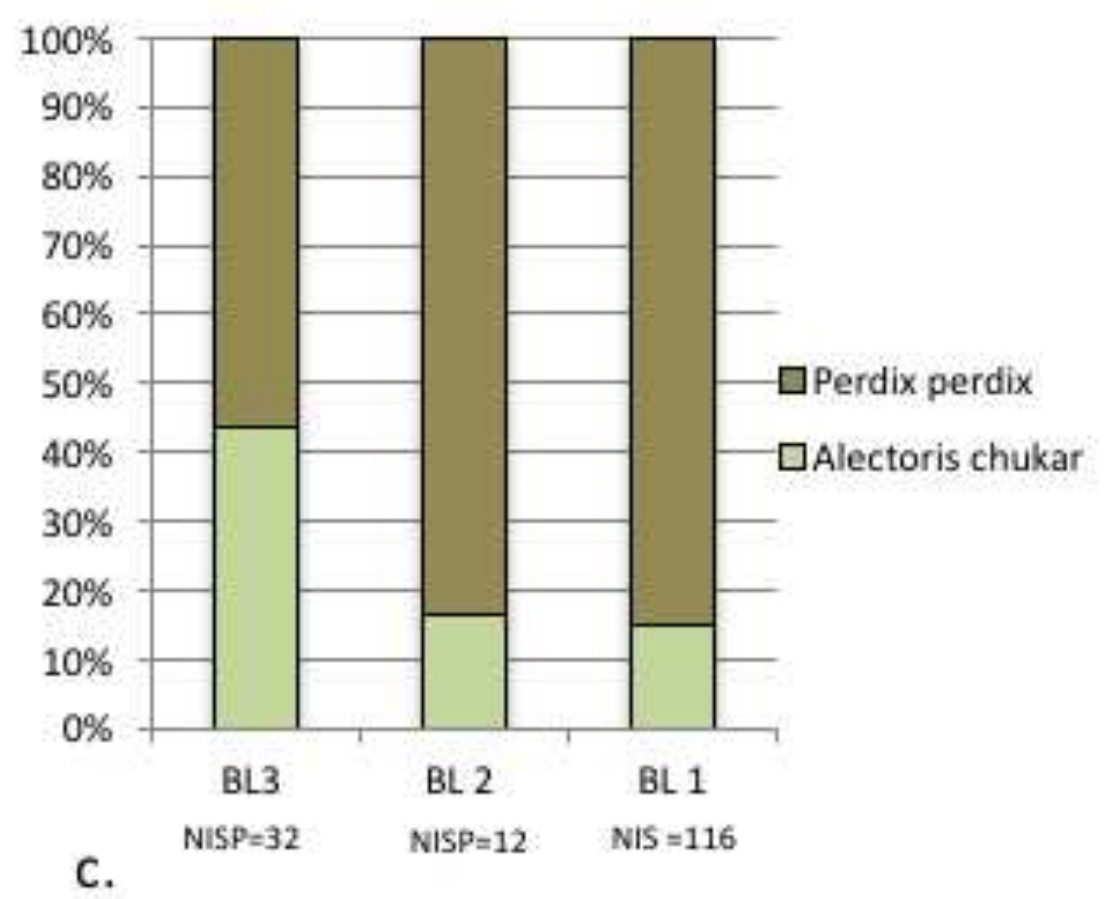

$\square$ Gamebirds

口Waterfow|

b.

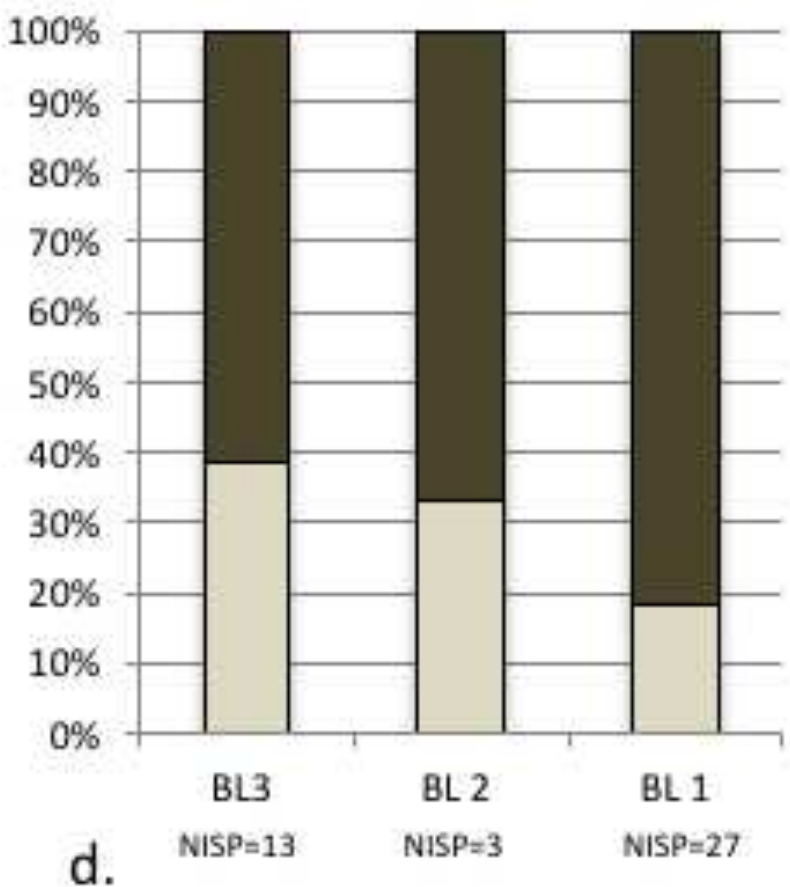

$N \mathrm{SP}=13$

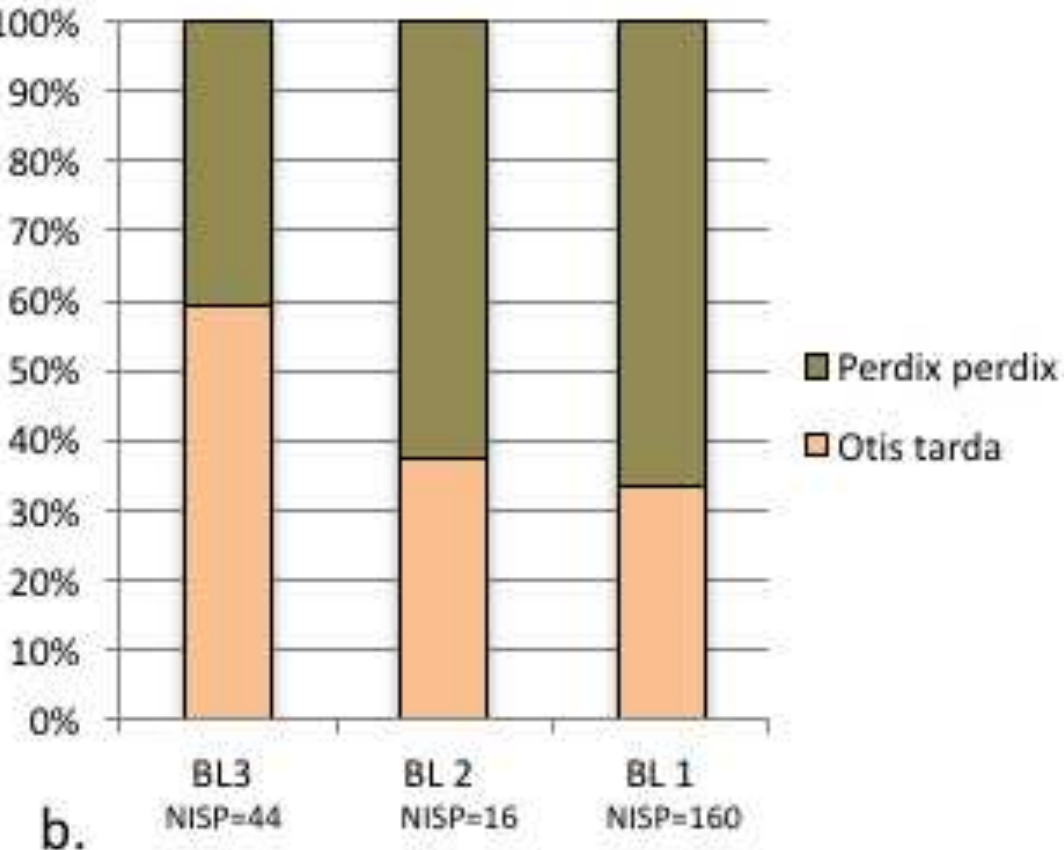

口Perdix perdix 口Otis tarda

Bubo

$\square$ Aquila 

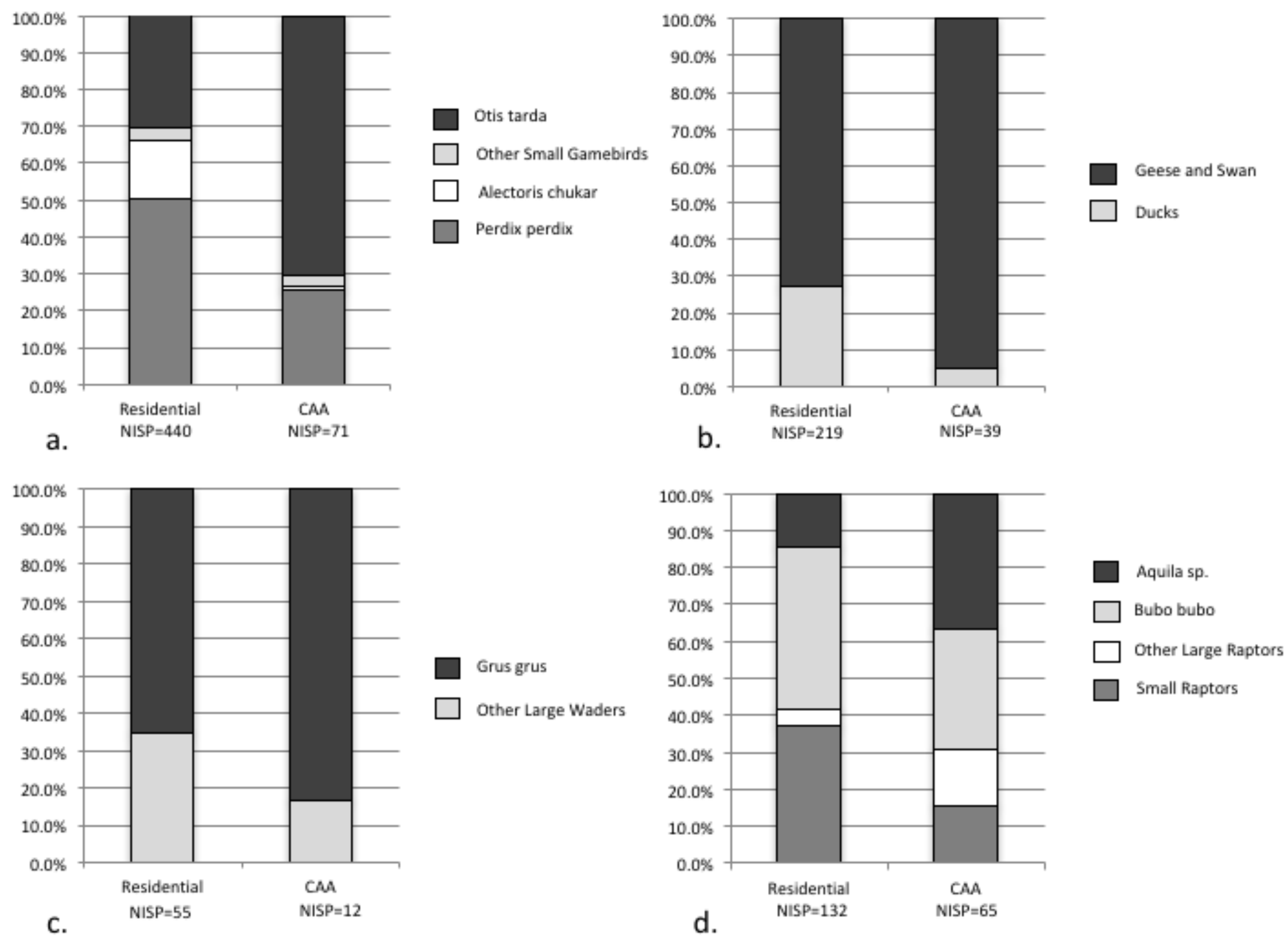

\section{Figure8B\&W}




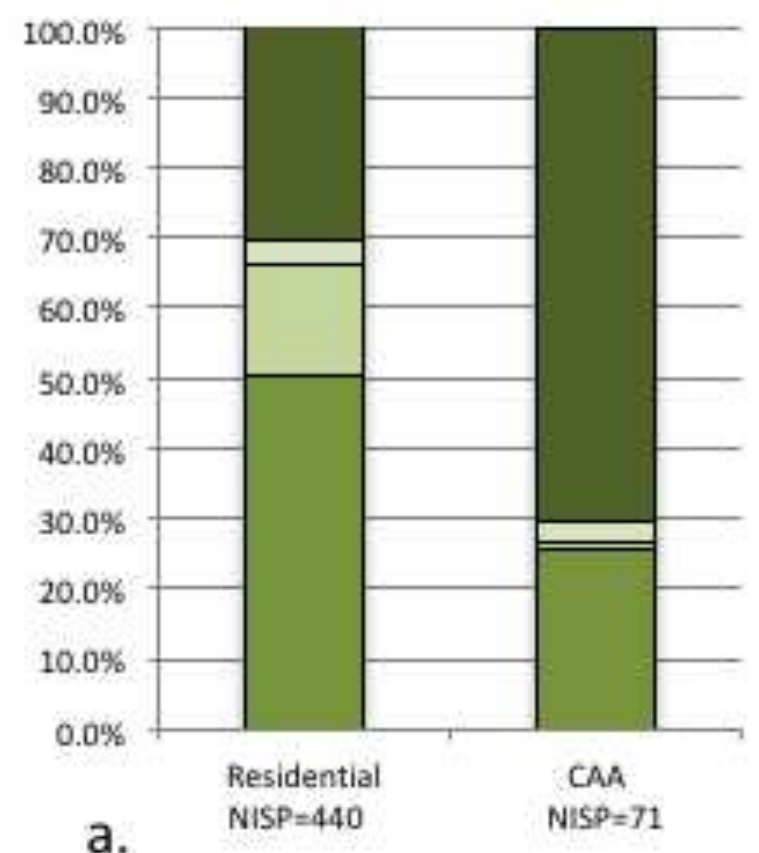

a.

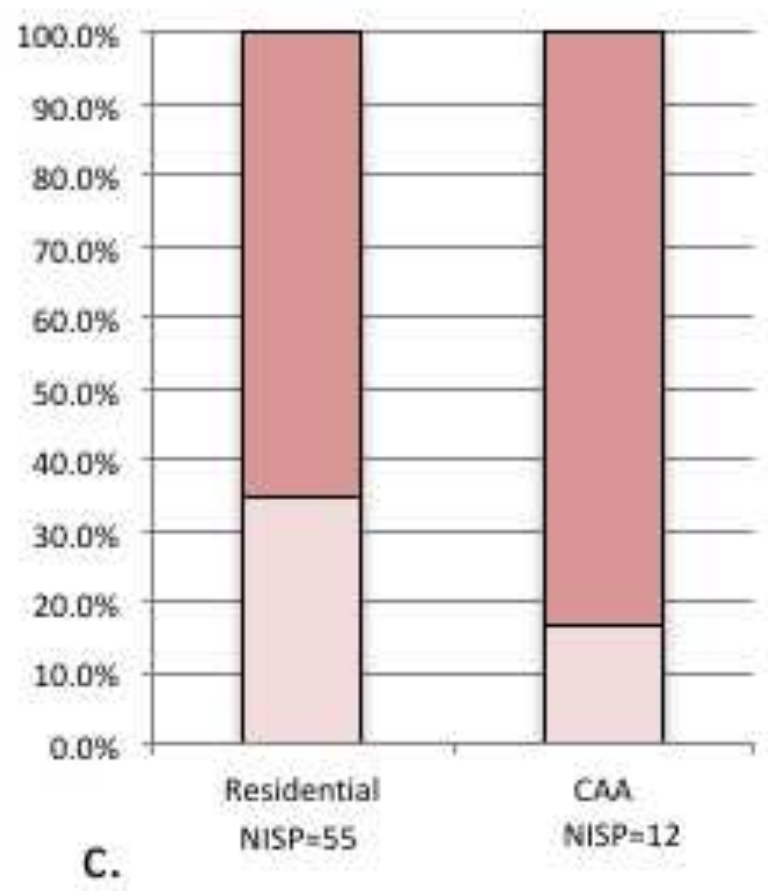

$\square$ Otistarda

$\square$ Other Small Gamebirds

$\square$ Alectoris chukar

Perdix perdix

\section{Grus grus}

Other Large Waders

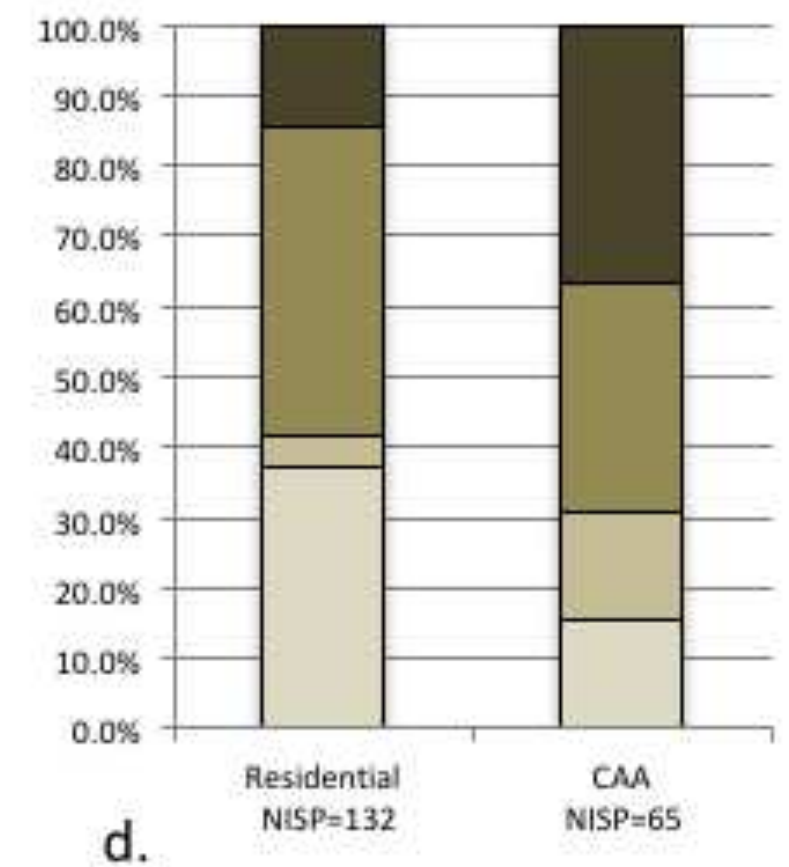

Geese and Swan Ducks

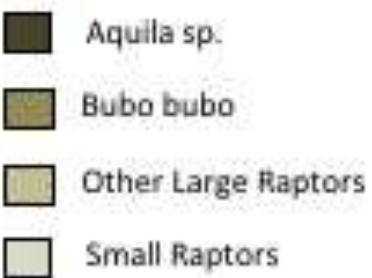

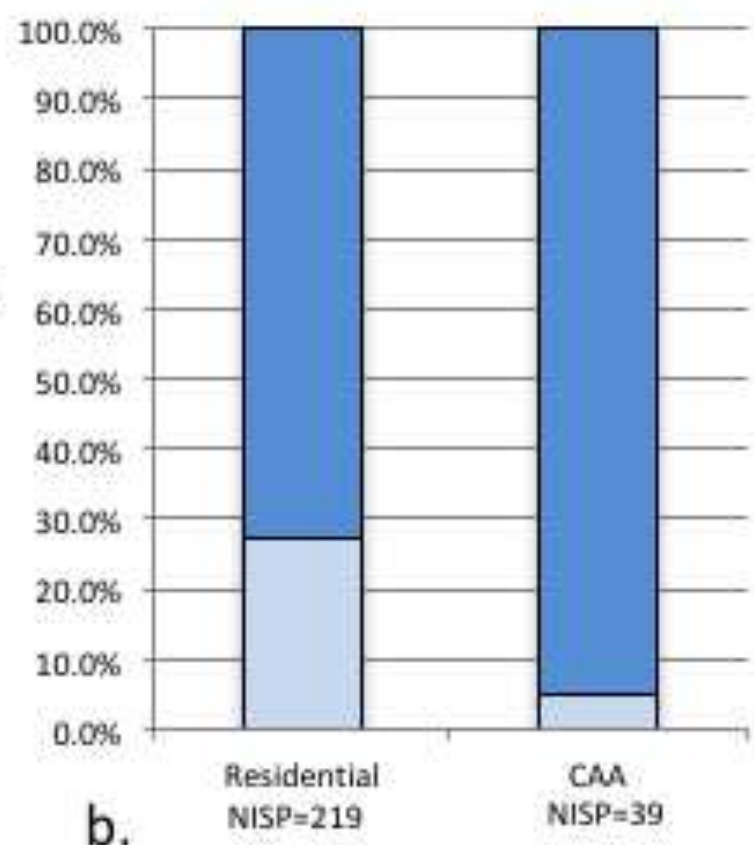




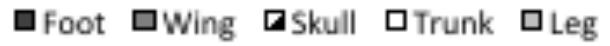

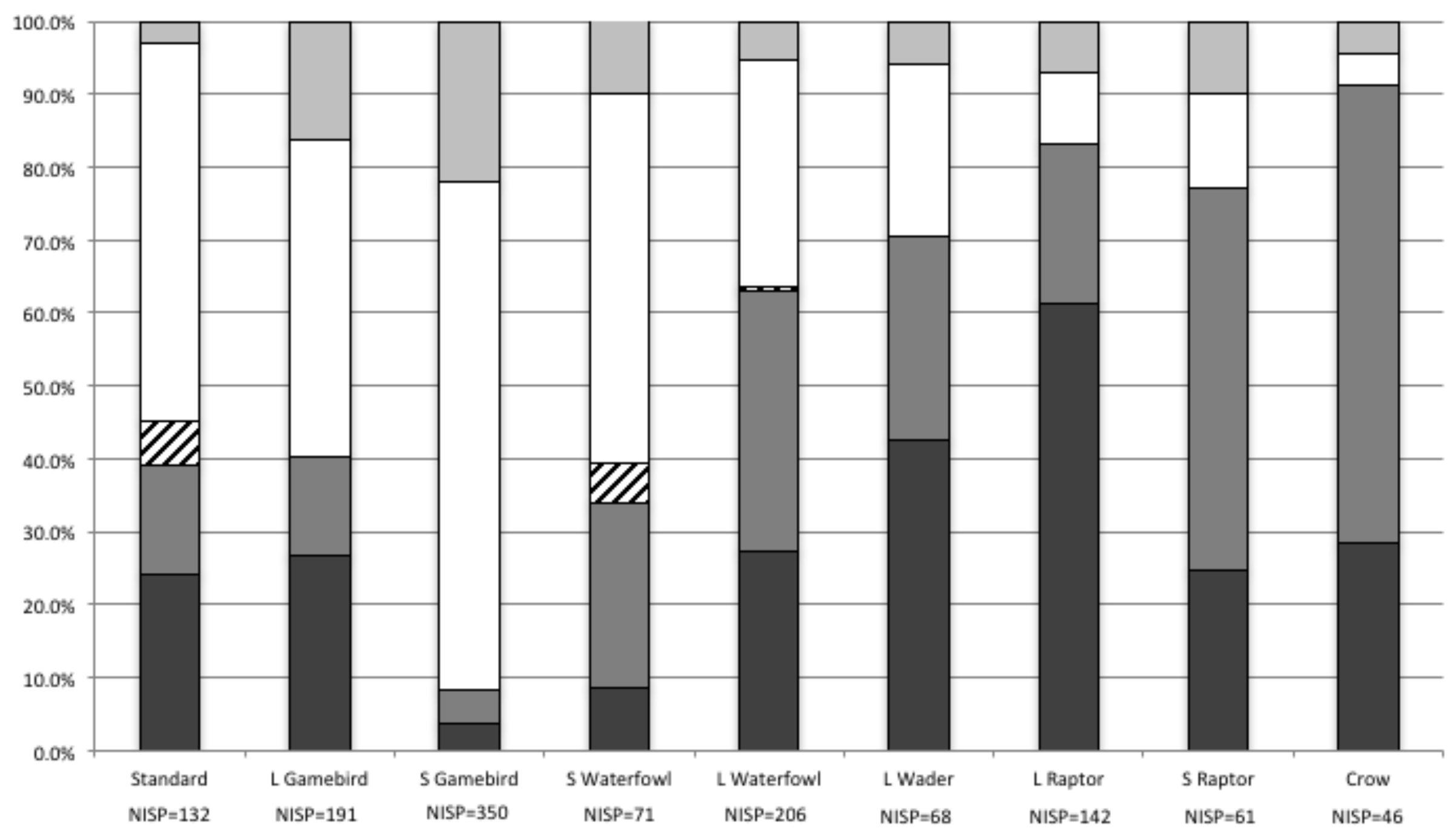




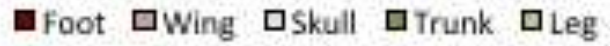

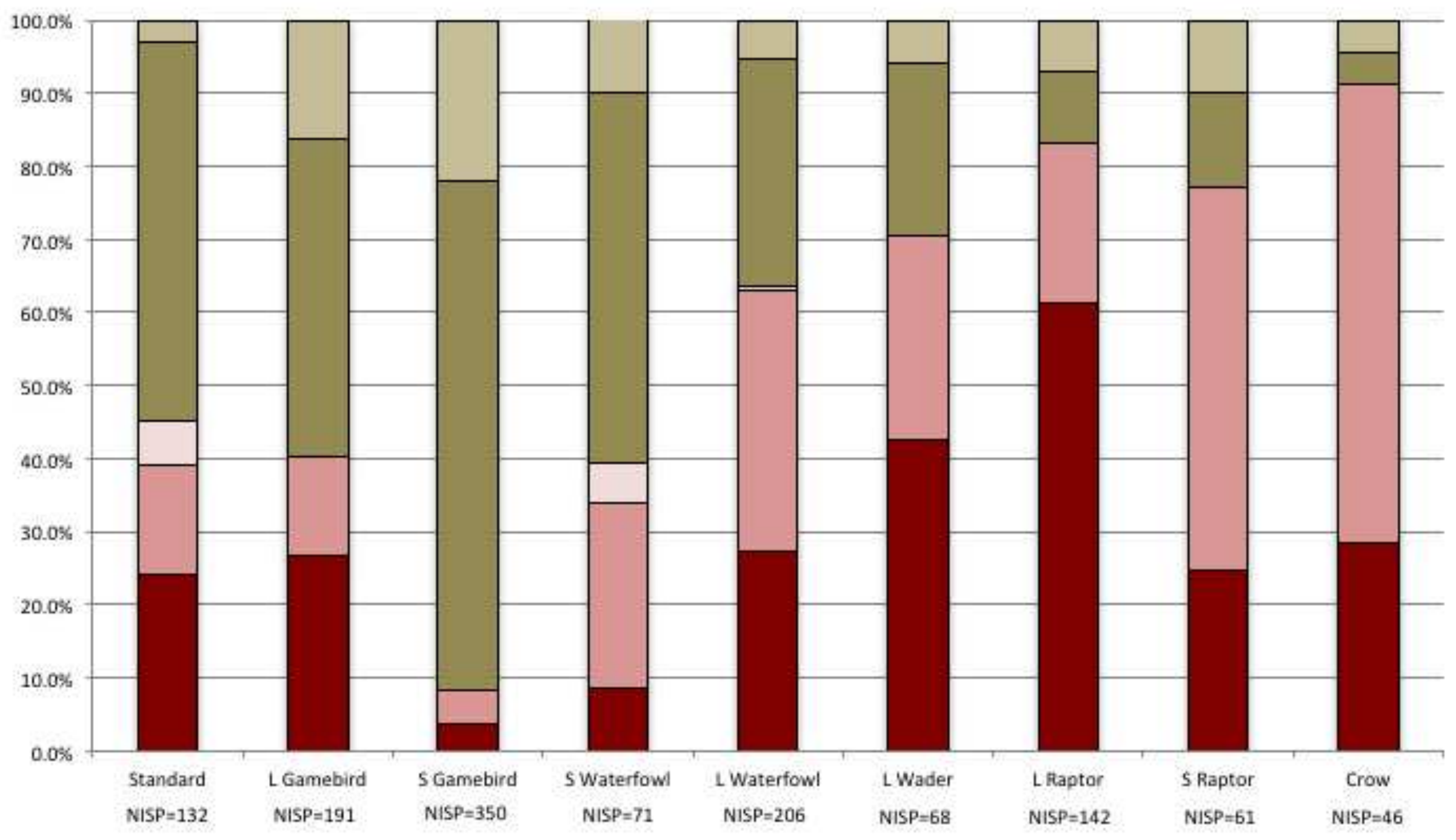


$\square_{\text {foot }} \square_{\text {Wing }} \mathbf{\square}_{\text {Skull }} \square_{\text {Trunk }} \square_{\text {Leg }}$

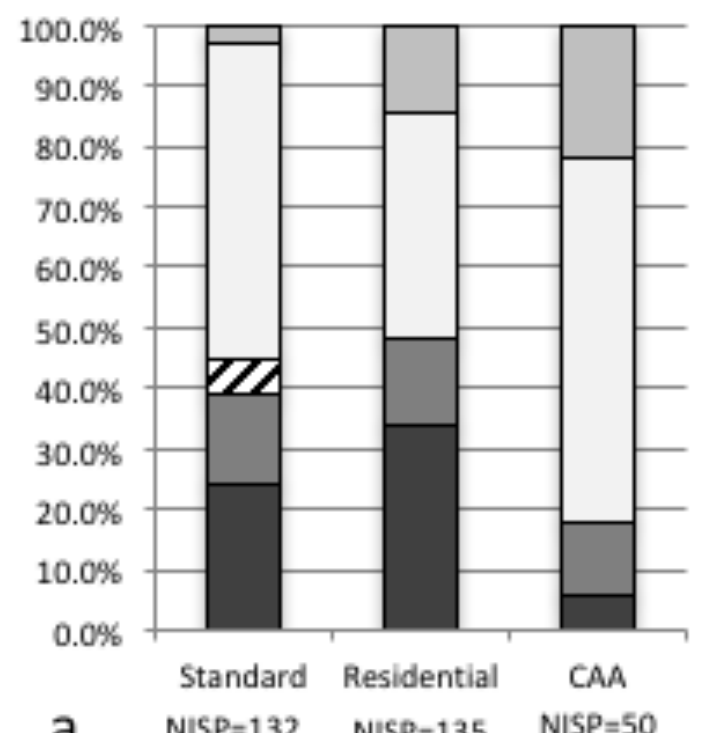

$\square_{\text {foot }} \boldsymbol{D W}_{\text {Wing }} \boldsymbol{\nabla}_{\text {Skull }} \boldsymbol{\square}_{\text {Trunk }} \boldsymbol{\square}_{\text {Leg }}$

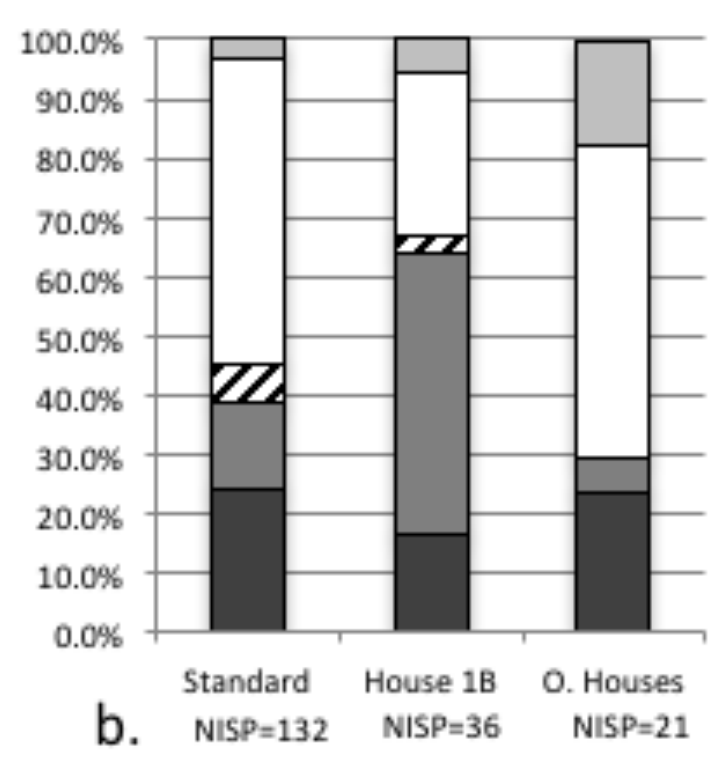

$\nabla_{\text {foot }} \nabla_{\text {Wing }} \boldsymbol{a}_{\text {Skull }} \boldsymbol{\nabla}_{\text {Trunk }} \nabla_{\text {Leg }}$

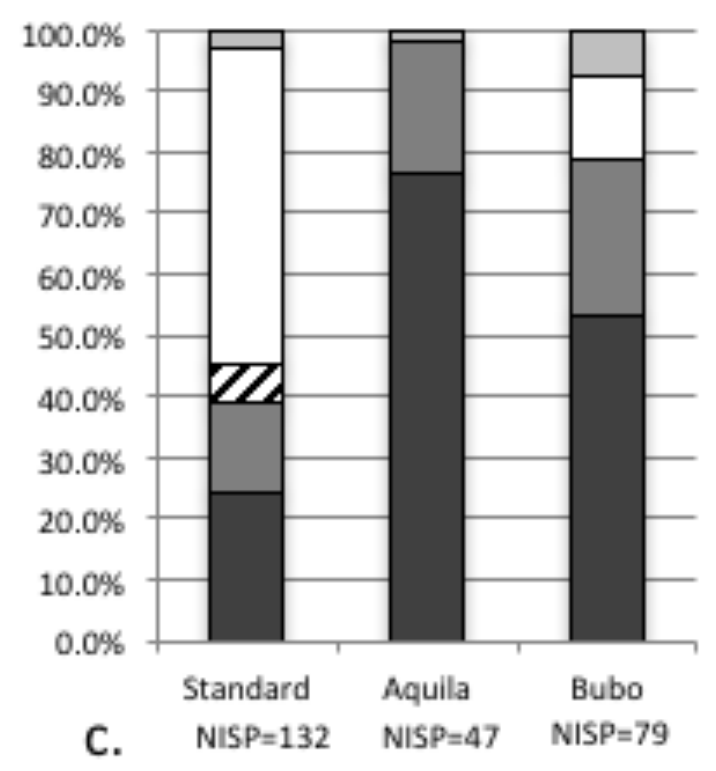


$\square_{\text {foot }} \square_{\text {Wing }} \square_{\text {Skull }} \square_{\text {Trunk }} \square_{\text {Leg }}$

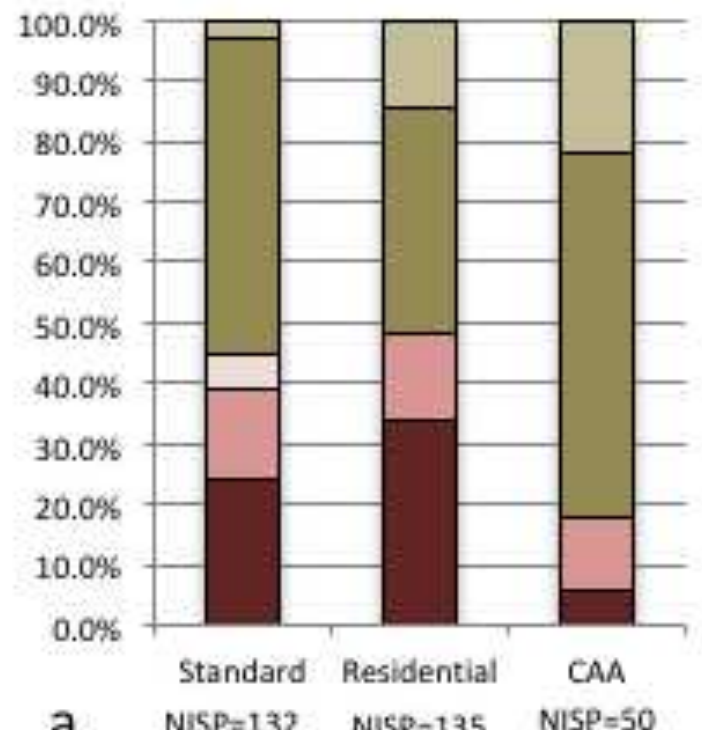

afoot $\square$ Wing $\square$ Skull $\square$ Trunk $\square$ Leg

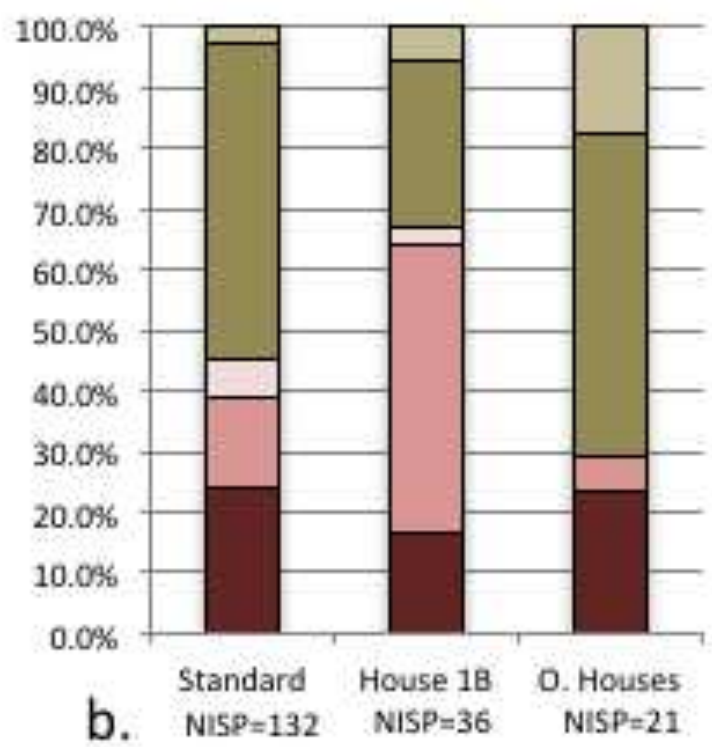

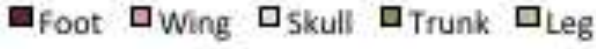

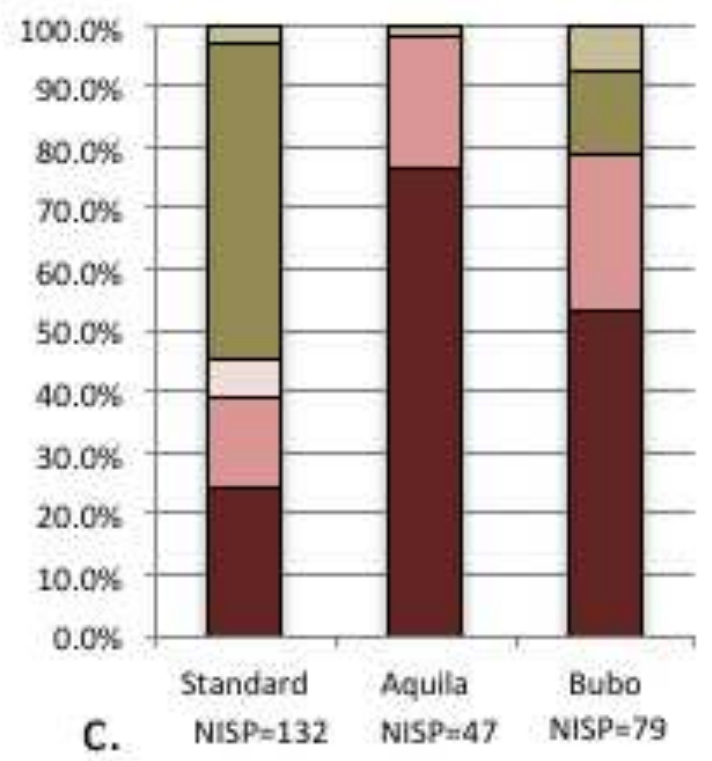




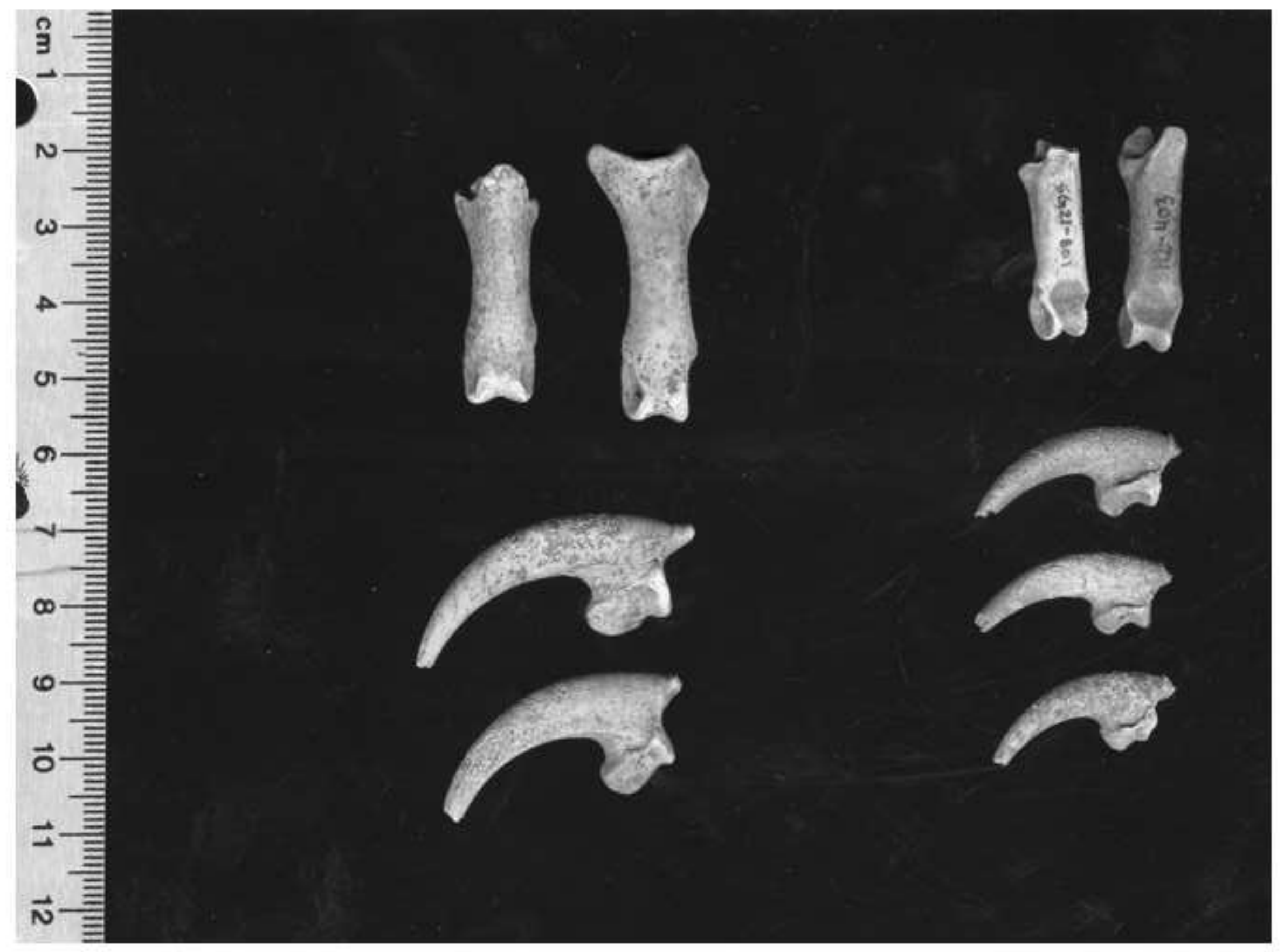




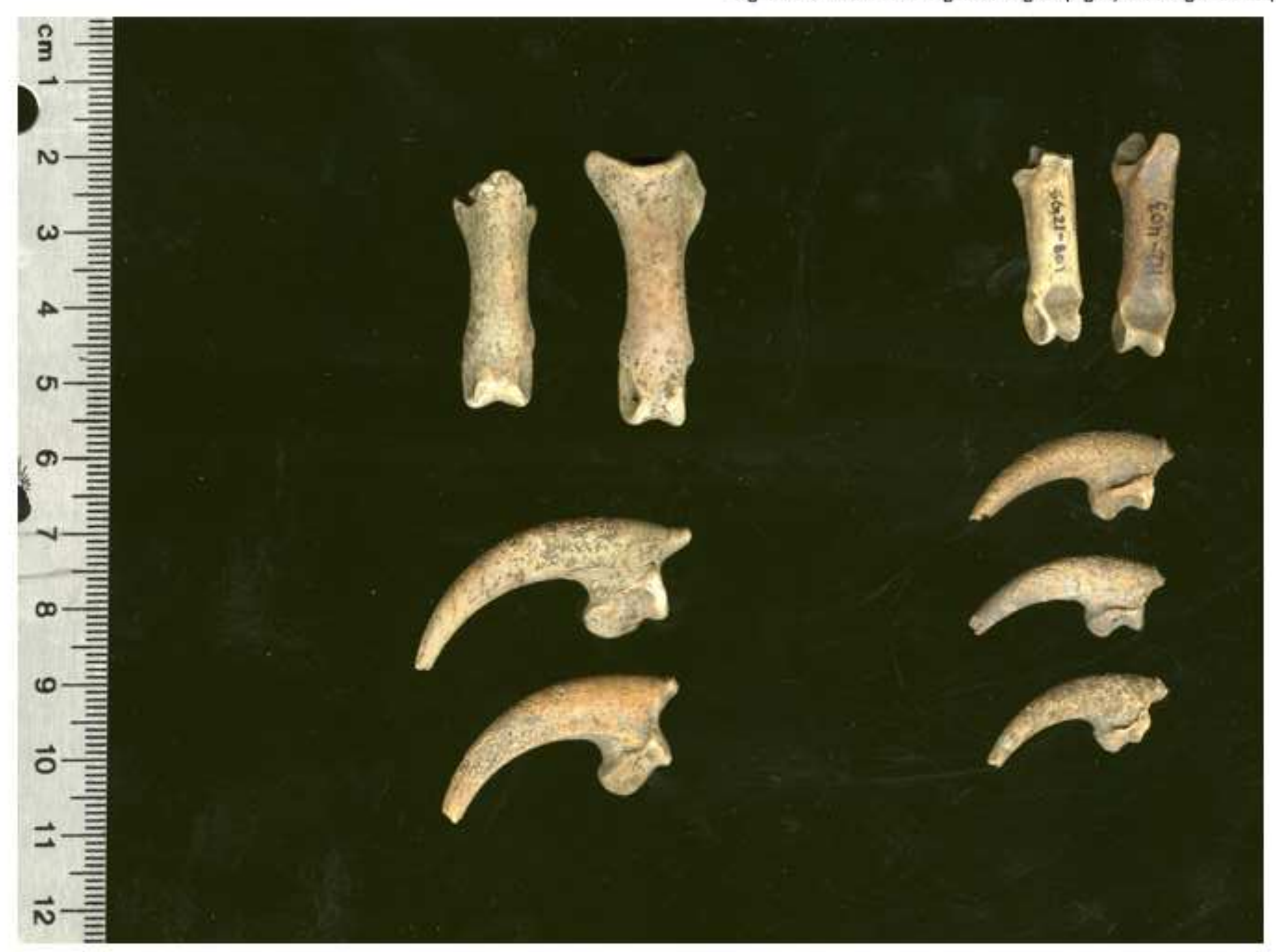

